\title{
Fighting Youth Unemployment: The Effects of Active Labor Market Policies
}

\author{
Marco Caliendo* $\quad$ Steffen Künn ${ }^{\dagger}$ \\ Ricarda Schmidl ${ }^{\ddagger}$
}

May 7, 2012

\begin{abstract}
A substantial number of young unemployed participate in active labor market programs (ALMP) in Germany each year. While the aims of these programs are clear - a fast re-integration into employment or enrollment in further education - a comprehensive analysis of their effectiveness has yet to be conducted. We fill this gap using administrative data on youth unemployment entries in 2002 and analyze the shortand long-term impacts for a variety of different programs. With informative data at hand we apply inverse probability weighting, thereby accounting for a dynamic treatment assignment and cyclical availability of programs. Our results indicate positive long-term employment effects for nearly all measures aimed at labor market integration. Measures aimed at integrating youths in apprenticeships are effective in terms of education participation, but fail to show any impact on employment outcomes until the end of our observation period. Public sector job creation is found to be harmful for the medium-term employment prospects and ineffective in the long-run. Our analysis further indicates that the targeting of German ALMP systematically ignores low-educated youths as neediest of labor market groups. While no employment program shows a positive impact on further education participation for any subgroup, the employment impact of participation is often significantly lower for low-educated youths.
\end{abstract}

Keywords: $\quad$ youth unemployment; active labor market policy;

JEL: program evaluation; propensity score weighting $\mathrm{J} 64, \mathrm{~J} 68, \mathrm{~J} 13$

\footnotetext{
${ }^{*}$ University of Potsdam, Germany; IZA Bonn, Germany; DIW Berlin, Germany; IAB Nuremberg, Germany. Corresponding author. e-Mail: caliendo@uni-potsdam.de. Address: University of Potsdam, Chair of Empirical Economics, August-Bebel-Str. 89, 14482 Potsdam, Germany. Tel: +49 3319773225 . Fax: +49 3319773210 .

${ }^{\dagger}$ IZA Bonn, Germany; University of Potsdam, Germany; e-Mail: kuenn@iza.org.

${ }^{\ddagger}$ IZA Bonn, Germany; University of Potsdam, Germany; e-Mail: schmidl@iza.org.

The authors thank participants at the 3rd annual joint IZA/IFAU Conference on Labor Market Policy Evaluation, the 2nd CIER/IZA Annual Workshop, the Conference for Equality of Opportunity in Rome, the IZA Summerschool 2011 as well as participants at the ESPE in 2010 and 2011 for valuable comments. The Institute for Employment Research (IAB) in Nuremberg kindly gave us permission to use the administrative data.
} 


\section{Introduction}

Young individuals entering the labor market are generally considered a population at risk, exhibiting an above-average turnover rate between jobs and an increased probability of entering unemployment. The employment situation of youths ${ }^{1}$ is also particularly sensitive to economic fluctuations (Verick, 2011), which was recently demonstrated in the aftermath of the financial crisis. Between 2008 and 2009, youths in the European Union experienced an increase in unemployment rates of about five percentage points to a $20 \%$ average, compared to a two percentage-point increase for adults to an average level of $11 \%{ }^{2}$

The prevalent youth-adult unemployment gap can be explained naturally by the initially low search skills and little work experience of labor market entrants, which results in increased levels of turn-over. Although this vulnerability is expected to be only transitory, some youths encounter difficulties during the school-to-work transition process caused by more structural problems. Recent studies on the youth labor market situation in developed countries show that a persistent share of youths experience longer-term unemployment spells, with a strong imbalance towards youths with low educational attainment (Quintini, Martin, and Martin, 2007). From an individual and a social perspective, this is a point of concern. Long unemployment spells are found to exhibit "scarring" effects on later labor market outcomes that seem to be more severe for young than for adult workers (compare, e.g., Ellwood, 1983). While the adverse effects on future employment probabilities are particularly persistent for low-educated youths (Burgess, Propper, Rees, and Shearer, 2003), the negative effects on wages seem to persist independently of individual characteristics (Gregg and Tominey, 2005). Potentially driven by foregone work experience or negative signalling, Korpi (1997) and Goldsmith, Veum, and Darity (1997) also show that the unemployment experience is associated with a decrease in subjective well-being and self-esteem, which might lead to a negative effect on current and future employment probabilities. In terms of social costs, there is evidence that rising levels of youths unemployment are not only related to an increase in spending on unemployment benefits and social assistance, but also to the depreciation of human capital, rising crime rates, drug abuse and vandalism (see Bell and Blanchflower, 2010, for an overview).

Against this backdrop, the majority of European countries spends significant resources each year to fight youth unemployment and improve the integration prospects of struggling youths. Active labor market programs (ALMP) are a common tool to achieve these goals. Between 1999 and 2002, countries in the EU-15 spent a yearly average of 1.3 billion euros on ALMP specifically targeted at unemployed youths (OECD, 2004). Although the primary objective of these programs lies in the fast integration in the first labor market, they may also target the continuation or take-up of vocational training for under-educated youths. The types of programs in use are manifold, ranging from targeted measures that account for the specific needs of labor market entrants, to the use of more "standard" ALMP, such as training, wages subsidies or job creation schemes. The prevalence of youth ALMP - introduced during the 1980s and 1990s - has continually increased during the

\footnotetext{
${ }^{1}$ We follow the general definition of youth as being 25 years or younger.

${ }^{2}$ Based on unemployment rates for youths (aged 15 and 24) and adults (aged 25 and 54) in 2008 and 2009 in the EU-27, from Eurostat.
} 
past decade. In 2007 the number of young ALMP participants in the EU-15 amounted to approximately $14 \%$ of the youth labor force (between 15 to 24 years). The quantitative importance of ALMP thereby stands in stark contrast to the low level of knowledge regarding their effectiveness. Existing evaluation results of youth ALMP in Europe provide a rather heterogeneous picture of program benefit ${ }^{3}$, suggesting that some of the measures implemented significantly reduce the employment probabilities of youths in the short to medium run. More evidence on the effectiveness of ALMP for youths is hence urgently needed to draw lessons for future policy design. Extrapolating from evaluation results for the adult workforce is misleading, given the distinctive characteristics of young labor market entrants. Moreover, the assessment of long-term effects is particularly important, as ALMP may not affect employment outcomes directly, but through their impact on participation decisions in longer-term education.

Our analysis uses Germany as a case study to contribute to the evaluation literature of youth ALMP in Europe. Due to data restrictions, so far no comprehensive quantitative analysis of the effectiveness of ALMP for youths in Germany was conducted. ${ }^{4}$ Our study aims to fill this gap. Even though Germany is considered a role-model of youth labor market integration, with its extensive dual-apprenticeship system, a non-negligible share of youths faces structural difficulties of integrating into the labor market. After leaving general education, youths face two stylized barriers: the transition from general education to vocational schooling or training ("first barrier") and the subsequent transition from training to employment ("second barrier"). ${ }^{5}$ In the late 1990s specific ALMP targeted at unemployed youths were put into place, with measures more suited to accommodate the specific barriers faced by youths. Participation in ALMP has since substantially increased, calling for a thorough assessment of their effectiveness. We analyze the impact of participation in various ALMP in Germany, including job creation schemes, wage subsidies, short- and longer-term vocational training measures, as well as measure aimed at promoting participation in the vocational training system. We use administrative data on an inflow sample of youths into unemployment in 2002, in which we observe participants and non-participants of ALMP for a period of six years, until 2008. The main outcome of interest is the probability to be in regular employment, but we also investigate the effects on participation in further education as an intermediate policy objective. The long observation period allows a meaningful assessment of the short- and long-term program impacts in both cases.

Exploiting the detailed information on individual pretreatment characteristics we identify the program impact in a quasi-experimental evaluation framework. Based on a justifiable conditional independence assumption, we apply Inverse Probability Weighting (IPW). To account for dynamic treatment assignment and differences in program availability, we estimate the treatment effects separately by elapsed unemployment duration and calendar

\footnotetext{
${ }^{3}$ See, e.g., Centeno, Centeno, and Novo (2009) for Portugal; Dorsett (2006) for the UK; Larrson (2003) for Sweden; and Brodaty, Crépon, and Fougère (2001) for France and Caliendo and Schmidl (2011) for a recent overview.

${ }^{4}$ Compare Ehlert, Kluve, and Schaffner (2010) for a recent evaluation of an innovative pilot project that was conducted in three German cities.

${ }^{5}$ See Dietrich (2001) for an in-depth discussion of the barrier-concept.
} 
month of entry into unemployment. We further account for the differential labor market characteristics of East and West Germany, by conducting the analysis separately for the two regions.

The setup of the paper is as follows. Section 2 briefly depicts the labor market situation of youths in Germany and the structure of the education system. Section 3 sets the stage for our evaluation by providing details on the estimation approach, the data used and the programs analyzed. Section 4 focuses on the implementation of the estimation strategy, and the results are presented in Section 5.

\section{Youth Unemployment and ALMP in Germany}

\subsection{The German Education System}

To set the stage for the following analysis it is helpful to briefly recall the structure of the German education and vocational training system (see Figure 1 for an overview). ${ }^{6}$ The general secondary schooling system precedes the selection into the vocational training system and has three parallel types of schools: low (Hauptschule), medium (Realschule) and high (Gymnasium) secondary schooling. The vocational training system ('upper secondary' and 'tertiary') accommodates a variety of pathways that differ with respect to their degree of work-training interaction and their academic content; the higher the academic content, the higher is the required secondary schooling certificate needed to enter. For pupils finishing the lowest type of school the only immediately available vocational training option is the dual apprenticeship, unless they decide to acquire a higher general schooling degree. Pupils who obtain a medium schooling certificate, regularly spent one more year in general schooling and can choose between entering the dual apprenticeship system or full-time vocational schooling, where a state-approved professional degree can be obtained outside the dual system, in a broader range of professions. Finally, pupils who finish the highest schooling type are allowed to participate in any type of vocational education (see shaded areas in Figure 1). The shares in Figure 1 indicate that medium secondary schooling is by far the most important one in Germany, with an average share of $38 \%(44 \%)$ of graduates in West (East) Germany. ${ }^{7}$ It can also be seen that youths in the East have on average a higher level of schooling attainment than their Western counterparts. In both regions a persistent share of $10 \%$ leaves lower secondary school with no certificate.

\section{INSERT FiguRE 1 ABOUT HERE.}

The dual apprenticeship system is the most important option of the vocational training system, accounting for roughly half of all entries each year; where the majority (roughly $80 \%$ in 2004) of the applicants has a certificate from a low or medium level school (see

\footnotetext{
${ }^{6}$ Unless otherwise indicated, the following section relies heavily on the official description of the German education system provided by the Kultusministerkonferenz Germany and the EURIDYCE Unit (2009).

${ }^{7}$ Statistics are taken from Bundesministerium für Bildung und Forschung (2009) and the Federal Statistical Office.
} 
Autorengruppe Bildungsberichterstattung, 2006). Since the demand for apprenticeships mostly exceeded supply in the early 2000s, access to the dual apprenticeship system is competitive and particularly problematic for youths with low previous educational attainment. Given that it is particularly these youths who have only few further options for obtaining vocational education, they are likely to enter unemployment at this "first barrier". At risk of experiencing longer unemployment spells or exiting into inactivity, an extensive preparatory/transitory training system has been put into place aiming to prepare these youths towards a successful entry into the apprenticeship system or other options of the vocational education (see Neumann, Schmidt, and Werner, 2010, for an overview). From 2000 to 2010, participation rates in the preparatory system have increased by about $50 \%$ - in years of low demand for apprentices, more youths enter the preparatory system than the apprenticeship system (Bundesministerium für Bildung und Forschung, 2009).

Due to the high labor market orientation of the vocational training system in Germany, the transition from vocational training into employment is generally characterized by relatively low levels of friction - although not all youths manage a smooth transition at this "second barrier". A lack of data that tracks youths after graduation from vocational education makes it difficult to assess the specific unemployment risks youths face after graduation. Reinberg and Hummel (2005) provide general figures for the unemployment risk of youths with different levels of vocational education. They show that individuals with no vocational qualification are up to three times more likely to be unemployed than youths with qualification - compared to youths with tertiary education they are eight times as likely.

\subsection{Youth Unemployment and ALMP in Germany}

To assess the particularities of the employment situation of youths compared to the general population, it is helpful to relate youth labor market outcomes to the ones of more senior workers. A persistent pattern to be found across all European countries is that youths are usually more likely to enter unemployment than adults, but that their unemployment spells are more transitory, i.e., they exit unemployment more often than older workers (compare, e.g., Caliendo and Schmidl, 2011, for a recent overview on the employment patterns of youths across the EU-15). Descriptive evidence on the overall economic conditions and the unemployment situation of youths in Germany during the period of our investigation exhibit a similar pattern, as can be seen from Figure 2. In particular, the youth-adult unemployment ratio gradually increased from almost identical levels in 2000 to about 1.5 in 2009 , whereas the long-term unemployment ratio oscillates persistently at around 0.5. Compared to the EU-average, where the unemployment ratio is around 2 to 3, youths in Germany face a comparably low risk of entering unemployment, which is generally attributed to the strong labor market link of the apprenticeship system. In terms of the probability for young people to enter long-term unemployment, however, Germany is amongst the European countries with the highest risk and this is clearly cause for concern. The rise in the youth-adult unemployment ratio during the observation period can be partially explained by the slowing German economy after 2000, but potentially also 
by an institutional reform in 2001, reducing the legal restrictions on part-time and fixedterm work. The extensive labor market reforms between 2002 and 2005 (the Job AQTIV Act and Hartz-reforms) further extended the realm of temporary work arrangements (see Jacobi and Kluve, 2007, for a more detailed description of the Hartz-reform changes), thereby leading to a strong increase in youths entering the labor market in "atypical" employment relationships with less stable long-term employment outcomes.

\section{INSERT Figure 2 ABOUT HERE.}

To fight unemployment Germany strongly relies on ALMP. The majority of ALMP schemes are financed by the federal government and the regulations regarding their implementation are contained in the Social Act III (SGB III). Unemployed youths who fulfill the eligibility criteria, are entitled to participate in the standard ALMP schemes available in the $S G B I I I$, e.g., training measures, wage subsidies, job creation schemes, etc. As part of the above-mentioned labor market reforms, significant adjustment of the implementation practice of ALMP were made after 2000, with the objective of reaching a faster activation of unemployed individuals. Besides an increase in monitoring efforts, this lead to the expansion of ALMP offering job search assistance and short-term training courses. Furthermore, the Job-AQTIV Act of 2002 integrated specialized youths measures within the $S G B I I I$, that became effective only in 2004. Before the integration of these measures into the $S G B I I I$, the only youth-specific ALMP on the federal level existed within the program of Immediate Action Program for Lowering Youth Unemployment (JUMP). JUMP was introduced in 1999, following an increasing importance of ALMP in European and German policy debate as means to deal with the increasing number of youths who were unemployed or unable to find an apprenticeship placement. By the provision of additional financial means of around one billion euros per year, and the facilitation the access to ALMP by reducing the eligibility criteria for unemployed and disadvantaged youths, it was intended to enable a faster integration of youths into ALMP. ${ }^{8}$ Furthermore, JUMP introduced some new measures specifically aligned to the requirements of unemployed youths, which have later on been partly integrated into the $S G B$ III. Originally set up for only one year, JUMP was extended each year and finally expired in 2004 (between July 2003 and December 2004 the program was called JUMP Plus intending to support 100,000 long-term unemployed youth).

\subsection{Programs under consideration}

Statistics from the German federal employment agency on the overall numbers of entries into ALMP indicate a substantial increase in participation rates among youths between 2000 and 2010. In 1999 around 600,000 youths were registered in ALMP within SGB IIIin 2009 the figure was 1.9 million. Between 1999 and 2003, there was on average an extra of 156,000 youths each year entering the programs of JUMP (see Dornette and Jacob, 2006, for a detailed participant structure of JUMP). Regarding the type of assistance offered,

\footnotetext{
${ }^{8}$ For a detailed synopsis of the objectives and measures associated to the introduction of JUMP, see Bundesministerium für Arbeit und Soziales/Bundesministerium für Bildung und Forschung (1999)
} 
the ALMP in place can be grouped into three broad categories. The most important one in terms of entry numbers are counseling and placement help, with about $60 \%$ (50\%) of all yearly entries in the $S G B I I I$ in East (West) Germany. ${ }^{9}$ Furthermore there are longerterm measures either aiming to promote the integration of youths into an apprenticeship or to help them integrate into the first labor market (training programs, wage and selfemployment subsidies, and job creation schemes). Participation in ALMP (compared to the workforce) is generally higher in East Germany, where labor market conditions are less favorable.

In our analysis we assess the impact of seven types of programs, which constitute the most important ones in terms of participation numbers during the period under study (compare Section 3.3). Table 1 contains a list of the programs, a brief description of their content and their duration. Similar programs offered in JUMP and SGB III simultaneously are grouped together if official implementation guidelines, participant structure and program duration suggested similar content. ${ }^{10}$

\section{INSERT TABLE 1 ABOUt HERE.}

Job search measures (JS) include job search monitoring and the assessment of the career opportunities of individuals. Short-term training programs (STT) offer courses of a very short duration to improve auxiliary skills that are important in the application process, e.g. computer classes or language courses. The intended short duration of both programs aims to facilitate job search activities during participation, so that locking-in in these programs is expected to be small. However, due to this short duration JS and STT measures are not suited to reduce structural deficits of labor market entrants. Often used as device to assess the employability of youths, it is particularly likely that youths participate in further ALMP subsequent to participation in JS or STT. As sequential program participation renders causal estimation of the impact of short-term programs more difficult, we address this issue in Section 5.3 specifically. Job creation schemes (JCS) and further training (FT) are longer-term measures with a median duration of five to seven months, aimed at overcoming more structural problems of integration in the labor market. JCS are predominantly practically oriented, providing some type of work experience for youths with very little previous labor market experience and potentially low labor market attachment. Although participants receive only low levels of remuneration during program participation, locking-in in these programs is expected to be high for youths with few outside options. In contrast, FT measures are predominantly focused on youths with vocational qualification, who seem to require additional qualification to succeed in the labor market. The program usually comprises classroom training and may vary between part- or full-time courses.

\footnotetext{
${ }^{9}$ Shares are provided by the statistical office of the federal labor agency; entries into ALMP between 1999 to 2009 without mobility aid, which technically only includes a cash-transfer to increase the mobility of youths.

${ }^{10}$ The administrative data used contains a very detailed listing of programs, differentiated by content and sources of funding, we aggregate programs with comparable content. In the case where JUMP contained a program similar to the regular activation measures, we compared the two measures with respect to their duration, participant structure, etc. and formed a common group only if they did not significantly diverge.
} 
In contrast to these supply-oriented measures, the wage subsidies offered within the $S G B I I I$ (WS) and JUMP (JWS), are aimed to overcome demand side restrictions. The two programs differ with respect to the size of the subsidy and the time period for which it is granted. While the subsidy in WS was regularly limited to one year and provided $50 \%$ of the monthly wage, JWS could either be taken up for one year and $60 \%$ replacement, or two years and $40 \%$ of replacement; employers had to guarantee a period of post-subsidy employment which was equivalent to the subsidized period for WS and half the subsidized period for JWS. While the objective of the previous programs is a direct labor market entry, preparatory practical training measures (PT) aim to enhance the chances of youths struggling at the "first barrier", i.e., at entering the vocational training system. The program consists in a subsidized internship within a firm where predominantly basic practical skills and literacy are conveyed. Some employers might also use this as a probation period before offering a full apprenticeship position within the firm.

\section{Estimation Strategy and Data}

\subsection{Identification of causal effects}

We base our analysis on the potential outcome framework (Roy, 1951; Rubin, 1974) where $D$ denotes the treatment indicator, $Y^{1}$ the potential outcome in the case of treatment $(D=1)$ and $Y^{0}$ the outcome without treatment $(D=0)$. The observed outcome for each individual $i$ is given by $Y_{i}=Y_{i}^{1} \cdot D_{i}+\left(1-D_{i}\right) \cdot Y_{i}^{0}$. Our aim is to estimate the average treatment effect on the treated (ATT) on the population level that is formally given by $\tau=$ $E\left(Y^{1} \mid D=1\right)-E\left(Y^{0} \mid D=1\right)$. As we are faced with the fundamental evaluation problem of not observing each individual simultaneously in the both the treatment and the nontreatment state, we need a meaningful substitute for the counterfactual (the second term on the right hand side). Approximation by the observed average non-treatment outcome of the non-treated, i.e., $E\left(Y^{0} \mid D=0\right)$ does generally not lead to a meaningful estimate, as participants and non-participants are likely to be (self-)selected groups with differential outcomes even in absence of the program. In the absence of random treatment assignment selection into the treatment is assumed to occur systematically based on observable or unobservable characteristics (or both). ${ }^{11}$

In the case where the participation decision depends on observable characteristics $W$ only, we can estimate the ATT by conditioning on these variables, rendering the counterfactual outcome independent of treatment, i.e., $Y^{0} \amalg D \mid W$ (conditional independence assumption, CIA). Rosenbaum and Rubin (1983) show that instead of conditioning on a potentially extensive set of characteristics $W$ directly, conditioning on the probability of treatment participation $P(D=1 \mid W)$ (the propensity score) suffices to achieve balance between treatment and control group. To ensure that we can find an adequate counterfactual for each treated individual it is furthermore required that the covariates influencing assignment and outcome do not deterministically predict treatment participation, i.e. that $\operatorname{Pr}(D=1 \mid W)<1$ holds for all $W$ (weak overlap). Furthermore, it is required that gen-

\footnotetext{
${ }^{11}$ See, e.g., Caliendo and Hujer (2006) for further discussion.
} 
eral equilibrium effects do not occur, e.g., the treatment participation of one individual can not have an impact on the outcomes of other individuals, independent of their treatment participation (stable unit treatment value assumption, SUTVA). The validity of this assumption is likely to depend on the scope of the program as well as size of the resulting effects (Imbens and Wooldridge, 2009). As on average only 12\% of the active youth population in Germany participated in ALMP from 2000 to 2007, the scope for general equilibrium effects seems rather limited in our case, so that we expect the SUTVA to hold.

The validity of the CIA is more difficult to justify, as it requires that all relevant variables that simultaneously influence participation and outcome can be controlled for (compare, e.g., Smith and Todd, 2005 or Sianesi, 2004). The availability of informative data is therefore crucial. Although there is no common rule on the particular set of information necessary, the ALMP evaluation literature provides helpful guidance on the question which variables to include. Lechner and Wunsch (2011) argue that more information lowers the bias, and highlight the importance of information on labor market history, caseworker assessments, job search effort, timing of unemployment and program start, health indicators, characteristics of last employer and regional characteristics. As our data is based on detailed administrative records, we are able to reproduce the set of variables suggested by Lechner and Wunsch (2011) to a very large extent (see Table 4). When dealing with youths, however, the importance of, e.g., observing past labor market histories to capture relevant but potentially unobservable selection variables (motivation, labor market skills, regional particularities, etc.) is likely to lose substantial power as labor market biographies do not yet exist, or are only limited. Hence, besides including labor market histories for those youth who have already labor market experience (employment and earnings, unemployment, inactivity and treatment participation during the three years prior to unemployment entry), we also include further productivity signals which are likely to justify the CIA. Specifically, we rely on information from the caseworkers (number of placements offers and last contact to labor agency before current unemployment spell) which show to be powerful predictors of treatment assignment. This is not surprising as the caseworkers perception on the labor market performance of unemployed is likely to be more important for the participation decision of low experience youths than for adults. Provided with this additional strong signal of unobserved ability of young unemployed, we argue that the CIA is a reasonable identification strategy in our context.

\subsection{Definition of Treatment and Control Group}

To estimate causal effects in the potential outcome framework, the definition of the treatment status requires clarification. Our question of interest is whether participation in an ALMP program has an impact on labor market outcomes of youths, in contrast to a situation where the program had not been available. In our setting, all unemployed youths are potentially eligible to participate in a program - and they may do so at different points in time - which complicates the straightforward definition of a group of participants and nonparticipants. As pointed out by Sianesi (2004), defining a treatment group by conditioning on ever observing individuals in treatment simultaneously restricts the control group to 
individuals who have successfully exited into employment before they could participate in a program, which would introduce bias in the effect estimates.

In the evaluation literature two streams exist to deal with this issue, a "static" and a "dynamic" approach. The dynamic approach makes no direct assumptions about the occurrence of the treatment but considers the timing of treatment as a stochastic process. ${ }^{12}$ For the definition of the two groups this means that the distinction between treated and controls is made recurrently at each point in time, based on the observed state of all eligible individuals, and is therefore independent of any treatment status at a later point. Although this selection mechanism is realistic in our setting, the approach has the disadvantage of limited interpretability of the estimates. As the control group includes future program participants, the estimated effects have to be seen as a mixture of "participation vs. nonparticipation" and "participation now vs. participation later" (see Lechner, Miquel, and Wunsch, 2011). In the case of multiple available programs the estimated effects additionally include a relative effect compared to participation in a different program. The static approach on the other hand considers participation vs. non-participation in a particular program based on observing individuals up to a pre-determined point in time and thereby requires conditioning on future outcomes for the non-treatment group (Lechner, Miquel, and Wunsch, 2011). The interpretation of the estimated effects is more obvious as only "never-treated" (within a certain time period) non-participants contribute to the counterfactual outcome. As pointed out, the restriction on future outcomes is likely to create a control group consisting of a positively selected subgroup of all eligible unemployed and might therefore bias the results downwards. ${ }^{13}$

As we are interested in the effect of participation vs. non-participation, and given the variety of ALMP offered in Germany which render relative effects rather untransparent, we follow Lechner, Miquel, and Wunsch (2011) and apply the static evaluation approach. ${ }^{14}$ To do so we have to define a cut-off in unemployment duration at which individuals are assigned to the treatment group (if they participate before the cut-off) and control group (if not). The choice of the cut-off should balance two opposing influences. On the one hand, the estimation bias due to the restriction on future outcomes is increasing with the time window (Fredriksson and Johansson, 2002); on the other hand, a small entry window increases the variance of the estimates due to lower observation numbers, and might also reduce the external validity of the results due to potential seasonal effects. Therefore, we decide to specify the first 12 months of unemployment as our entry window. First, this is not too restrictive on control outcomes since $50 \%$ (40\%) of non-treated individuals in East (West) Germany are still unemployed after 12 months. Second, it secures a sufficient number of treated observations and reduces the influence of seasonal effects as it captures the complete year. ${ }^{15}$ Hence, we assign youths to the group of participants if they enter

\footnotetext{
${ }^{12}$ See Abbring and van den Berg (2003, 2004) for a discussion in a duration model framework and Fredriksson and Johansson (2008); Sianesi (2004) for an application of semi-parametric matching.

${ }^{13}$ Lechner, Miquel, and Wunsch (2011) argue that this argument would even strengthen the effectiveness of programs in the case of positive results.

${ }^{14}$ We test the sensitivity of our results with respect to the choice of the evaluation approach and provide results using the dynamic approach in Appendix 6 .

${ }^{15}$ The dynamic changes in the selection process due to the changes in the composition of unemployed, and potential changes in the types of programs offered during this time period are controlled for in the
} 
an ALMP program under consideration (see Table 1) within the first 12 months of their unemployment spell and to the group of controls if not. Note, that we discard individuals who participate in any other program within the first 12 months. When individuals participate in multiple programs during their unemployment spell, we focus on the first one in the main analysis. ${ }^{16}$

\subsection{Data and Descriptives}

To assess the impact of program participation on labor market outcomes, we use data from the administrative part of the IZA Evaluation Dataset. ${ }^{17}$ It is based on the Integrated Employment Biographies (IEB) by the Institute for Employment Research (IAB) and consists of a random draw of unemployment entries between 2001 and 2008. It combines different administrative data sources, i.e., the Employment History, Benefit Recipient History, Training Participant History and Job Search History, and contains detailed daily information on spells in employment subject to social security contribution, unemployment, and participation in ALMP. ${ }^{18}$ Linked to the information on the respective labor market status, the data include information on income from wages and benefits, on the previous labor market history and socio-economic characteristics of individuals.

We restrict our estimation sample to unemployment inflows in $2002 .{ }^{19}$ This guarantees a sufficiently large observation window (at least 72 months after entry into unemployment) and allows us to obtain long-term impact estimates even for the longer running programs. Our choice of the year 2002 also takes account of the adoption of the JobAqtiv Act in the beginning of 2002, which entailed significant changes in the strategy of unemployment activation and implementation practice. Besides avoiding potential structural breaks in the implementation of programs between 2001 and 2002, the evaluation results for the programs under the new "regime" are also more relevant for current policy discussion, as their set-up resembles much more the set-up of programs in place today. Based on our initial inflow sample into unemployment in 2002, we only keep youths (aged 25 or younger) and apply several further sample selection criteria which are summarized in detail in Table A.1 in the Appendix. We end up with an estimation sample of 51,019 unemployment entrants, corresponding to 17,515 youths from East and 33,504 youths from West Germany. Applying the definition of treatment status as discussed above, we identify $5,353(7,027)$ youths in the East (West) participating in one of the programs under scrutiny within the first 12 months of unemployment. By restricting treatment to those ALMP entries in the first 12 months after unemployment entry, we capture about $62 \%$ $(65 \%)$ of all individuals who enter one of the programs in our total observation period

\footnotetext{
estimation process (see Section 4.2).

${ }^{16}$ About $50 \%$ (33\%) of treated in the East (West) participated in multiple programs during their unemployment spell, with about 10\% (5\%) participating in further ALMP within the first 12 months. However, we focus on the first program as subsequent program participation has to be considered as the outcome of the first treatment.

${ }^{17}$ For a detailed description of the IZA Evaluation Dataset see Caliendo, Falk, Kaiser, Schneider, Uhlendorff, van den Berg, and Zimmermann (2011).

${ }^{18}$ This does not include information about self-employment, civil servants or inactivity.

${ }^{19}$ Where we observe multiple entries into unemployment per individual, one spell is randomly drawn.
} 
of 72 months in the East (West). Non-participants are defined as individuals who do not participate in any ALMP within the first 12 months of unemployment but who are potentially treated later in months $13-72$, which is relevant for approximately $27 \%(14 \%)$ of non-participants in the East (West). Since the administrative data records only specific labor market states, we have missing observations for spells of schooling and education, military service, self-employment or inactivity. Some of these states are particularly likely to occur for young individuals. To overcome this problem we apply an imputation method that relies on information for the planned activity in the subsequent spell recorded within each spell and in case of unemployment spells for the last activity before unemployment. By this procedure we are able to fill $92 \%$ of all missing monthly information, decreasing the share of monthly missings from initially $25.7 \%$ to $2.1 \%$. Inspection of the type of information filled further reveals that non-randomly missing information does not pose a problem in our analysis (see Appendix A.2 for details).

Table 1 provides the number of observations for each of the programs under investigation and moments of the distribution of program duration. As expected we find that the majority of our participants enter short-term measures, i.e., job search (JS) and shortterm training measures (STT). Together, they account for almost half of participants in East and West Germany. This is naturally explained by our definition of treatment, as we focus on the first treatment after unemployment entry. Wage subsidies constitute the second most important types of measures. While WS are equally important in terms of participation shares in East and West, JWS are taken up twice as frequently in the East than in the West and have a longer duration. Furthermore JCS measures are used more extensively in East than in West Germany, potentially reflecting the lack of employment opportunities for low-educated youths in the East. Finally we find that PT are used in the West more often than in the East, with $14 \%$ of youths in the West and $10 \%$ of ALMP participants in the East.

\section{INSERT TABLE 2 ABOUt HERE.}

Table 2 provides selected descriptive statistics of the program participants in East and West Germany (measured on entering unemployment). About two thirds of program participants are male, with youths being usually older than 20 years. The regional migrant participation rates reflect the strong populations differences between East and West Germany with $3 \%(12 \%)$ of participants having a migration background in the East (West). Further differences across East and West emerge in terms of the pretreatment educational attainment. While the average program participant in the East has acquired a middle secondary school certificate, their counterpart in the West has a lower secondary school certificate. Furthermore, about $75 \%$ of youths in the East have already received some type of apprenticeship training compared to only about $50 \%$ in the West. In line with the observed differences in program importance this underscores that youths in the West seem to require help at overcoming supply-sided restrictions caused by their insufficient level of educational attainment, while unemployed youths in the East are rather held back by the low labor demand. For example, the importance of measures to overcome the "first barrier" in the West can be explained by the low schooling levels of West German youths. 
The comparison of participant characteristics across program types shows a clear divide in terms of labor market attachment. The labor market histories during the three years preceding unemployment entry show that youths in either type of wage subsidies (WS and JWS), longer-term training measures (FT) and job search assistance (JS) have spent more time in (full-time) employment, less time in inactivity (e.g. schooling), as participants in other programs and non-participants. Although they have spent a comparable amount of time in unemployment, they are also slightly older, have received a larger number of placement offers during their current unemployment spell, and in the East they are also better educated than the rest. The greater attachment of these youths to the labor market compared to non-participants is somewhat suggestive of "cream-skimming" or at least a positive selection into these program based on these observed characteristics.

Individuals with adverse labor market prospects seem to be concentrated in JCS and PT programs. Given the differential objective of PT measures, the adverse characteristics (e.g., they are on average younger, did not obtain a school leaving certificate, and have received significantly fewer placement offers) of participants in PT are not surprising. The characteristics of JCS participants are similarly adverse, suggesting that it is also the low educational attainment that keeps them from integrating into the first labor market. Furthermore JCS participants are older and exhibit above average shares of youths with health restrictions in the East - suggestive of more structural difficulties of integrating in the labor market than the other program participants. Note, that the programs' objective (compare Section 2.3) is the provision of work experience but not the increase in educational attainment. The first descriptive assessment of program characteristics hence suggests that placement in JCS is not primarily seen as stepping stone to further employment, but more as last resort for keeping these youths in the labor force.

\section{Empirical Implementation}

\subsection{Inverse probability weighting}

Based on the assumptions outlined in Section 3.1, the treatment and control group can be made comparable by conditioning on the propensity score (PS), i.e., $E\left(Y^{0} \mid D=\right.$ $1, P(W))=E\left(Y^{0} \mid D=0, P(W)\right)$, which then identifies the the average treatment effect on the treated $\tau$. Based on the PS, different approaches have been suggested to estimate an adequate counterfactual outcome, where the predominately used methods are semiparametric matching or reweighting (see, e.g., Imbens, 2004). The most suitable method has to be chosen depending on the study and context. Given our large set of covariates and the relatively homogenous groups of treated and controls we apply inverse probability weighting (Imbens, 2000, 2004). The IPW estimator has preferable finite sample properties compared to different matching algorithms under the requirement that the propensity scores are estimated and the weights are normalized to one (shown by Busso, DiNardo, and McCrary, 2009, in a Monte Carlo study). Huber, Lechner, and Wunsch (2010) also show that IPW performs well under extensive variation of the data set-up, although it is outperformed by some advanced matching estimators. Given the major advantage of 
a lower computational burden during the bootstrapping procedure for the estimation of standard errors IPW seems to be an appropriate choice in our setting.

The idea of IPW is to adjust the outcomes of the non-treated by weighting them with the inverse of the estimated propensity scores $\hat{P}(W)$. The estimate of our parameter of interest $\tau^{I P W}$ is then obtained as the difference between the average outcome of the treated and the reweighted average outcome of the non-treated:

$$
\tau^{I P W}=\left[\frac{1}{N^{1}} \sum_{i \in I^{1}} Y_{i}\right]-\left[\sum_{i \in I^{0}} \frac{Y_{i} \hat{P}\left(W_{i}\right)}{1-\hat{P}\left(W_{i}\right)} / \sum_{i \in I^{0}} \frac{\hat{P}\left(W_{i}\right)}{1-\hat{P}\left(W_{i}\right)}\right]
$$

where $\hat{P}\left(W_{i}\right)$ is the estimated propensity score and the division of the counterfactual outcome by $\sum_{i \in I^{0}} \frac{\hat{P}\left(W_{i}\right)}{1-\hat{P}\left(W_{i}\right)}$ ensures that the weights add up to one (see Imbens, 2004). One concern associated with IPW is that it is particularly sensitive to large values of the propensity scores as they receive disproportionately large weights in the construction of the counterfactual (see Frölich, 2004). However, the relevance of this problem decreases with sample size as each observation has asymptotically less influence on the estimate (Huber, Lechner, and Wunsch, 2010). This problem should only play a minor role in our study as we apply a very restrictive common support condition (see Section 4.3) and have a large number of non-treated observation which leads to an average treated-control ratio of approximately 1 to 20 . In addition, we test the sensitivity of our results with respect to this issue in Section 5.3 by trimming the distribution of the propensity scores of the non-treated.

\subsection{Perfect Alignment of Treatment and Control Groups}

As pointed out by the previous literature, participant characteristics and the type of treatment received may vary with the timing of entry into a program (compare, e.g. Sianesi, 2004 and Fitzenberger and Speckesser, 2007). As we define treatment over a period of 12 months after entry into unemployment we need to take into account potential dynamics in the selection into treatment or out of unemployment during this period. To mimic the selection process up to a particular point in time only individuals with similar unemployment durations should be compared. Given the small number of monthly treatment entries in our sample, estimation of the propensity score within monthly cells is not feasible. Instead we adopt an approach suggested by Fitzenberger and Speckesser (2007), consisting of stratified estimation of the PS within larger time windows combined with a "perfect" (i.e. monthly) alignment of treated and controls for the estimation of the treatment effect.

For the estimation of the PS we stratify the sample of treated into three subgroups based on their elapsed unemployment duration until treatment entry: (1) one to three months of unemployment duration, (2) four to six months and (3) six to twelve months. The treatment group in the respective cells hence consists of all individuals receiving treatment within these months of their unemployment spell. The control group consists of youths who are still unemployed in the first months of the respective stratum and who are not treated in the first 12 months of their unemployment spell. Based on the estimated propensity score, weighting of the controls is done within the "alignment cells". 
Besides aligning individuals perfectly on the month of entry into the program, we further take account of seasonal labor market conditions and program variability across calender time (see Sianesi, 2004), by aligning individuals perfectly by calender month of entry into unemployment. ${ }^{20}$ The construction of counterfactual is hence done within monthly cells of both the unemployment entry and unemployment duration, whereby only controls receive weights that were unemployed at least until the month of program entry of the treated. The resulting estimator can be written as:

$$
\tau^{I P W}=\frac{1}{N^{1}} \sum_{c=1}^{12} \sum_{p=1}^{12} \tau_{c p}^{I P W} \cdot N_{c p}^{1}
$$

where $\tau_{c p}^{I P W}$ is then estimated in each cell following Equation (1). $N^{1}$ denotes the total number of treated and $N_{c p}^{1}$ the number of treated in each cell defined by calendar month of unemployment entry $c$ and the months in unemployment before treatment entry $p$. As the estimation of treatment effects within each cell yields 144 single effects $\tau_{c p}^{I P W}$, with $c$ denoting calendar month of entry into unemployment and $p$ the month of entry into treatment, we aggregate the single effects to $\tau^{I P W} .{ }^{21}$ The aggregation is obtained by creating a weighted average of the monthly effects, with weights being determined by the distribution of monthly program starts and monthly unemployment entries among participants. See A.3 in the Appendix for a more detailed description of perfect alignment.

\subsection{Propensity Score Estimation and Weighting Implementation}

Table 3 provides the number of observations for each of the three subgroups of treatment entry. It can be seen that treatment participation is strongly concentrated on the first quarter of unemployment duration - except for the case of JCS in the East, where youths are most likely to enter after six months in unemployment. It can also be seen that controls are highly likely to exit unemployment during the first quarter of their unemployment spell. In particular, we see a reduction of the control sample for about one quarter (one third) in the East (West) during the first three months in unemployment. Despite the reduction in sample sizes with increasing unemployment duration, each time window contains a sufficient number of treated and controls to obtain a meaningful estimate of the propensity score.

\section{INSERT TABLE 3 ABOUt HeRE.}

For each program we estimate three binary probit models on participation in the program vs. not participating in any program within each of the respective time windows. The specification of the respective models was chosen as to include all covariates that potentially influence the selection into treatment and the success of the program. Table 4 contains a listing of the covariates used in our preferred specification. We include all

\footnotetext{
${ }^{20}$ Note, that the propensity score specification includes indicators for the calendar month of unemployment entry

${ }^{21}$ Note that while treated are assigned to mutually exclusive cells defined by $c_{1}$ and $p_{1}$, they are opposed to non-treated with the same entry into unemployment $c_{1}=c_{0}$ but $p_{1} \leq p_{0}$.
} 
variables that show up highly significant in at least one of the models. We only modify the estimation when there is a lack of variation between treated and controls in the respective time windows. ${ }^{22}$ Given the differential characteristics of program participants, the sign and power of control variables in predicting treatment vary strongly across programs and entry time, in particular for the extensive set of information on past labor market history. Independent of program, the most important variables include schooling and vocational training information, calendar month of entry into treatment; potential entry in 2003; last contact to the employment agency; and the number of placement offers. ${ }^{23}$ The latter two variables are of particular interest, as they proxy the closeness between youths and the employment agency and give potential signals for the labor market performance of youths as perceived by the caseworker. In particular, we observe a strong and significant inversely U-shaped relation between placement propositions and treatment participation for all programs except PT, which means that youths with extremely low or high number of employment options are less likely to participate in ALMP.

\section{INSERT TABLE 4 ABOUt HERE.}

Based on the predicted values of the propensity scores, weights are constructed within each of the 144 cells. To ensure that we only compare individuals with similar values of the PS and reduce the incidence of extreme values in the PS distribution we exclude observations outside the region of common support by dropping treated and non-treated individuals who have PS values above (below) the maximum (minimum) value of the respective other group (Dehejia and Wahba, 1999). This predominantly yields to a deletion of non-treated individuals at the lower end, and very few treated individuals at the upper end of the PS distribution (see Table S.1 in the Appendix). ${ }^{24}$ After imposing common support we perform weighting for all outcomes in each of the 60 months following program entry to obtain the short-, medium- and long-term treatment effects; standard errors are obtained by bootstrapping the entire matching procedure (including propensity score estimation) using 200 replications.

\subsection{Balancing tests}

As the essential objective of IPW is to balance the distribution of observable characteristics between participants and non-participants, we test the success of the procedure by comparing the differences in the distributions of covariates of treated and weighted controls. Among the many approaches to do so, we choose a simple comparison of means (t-test), and the mean standardized bias (MSB) in the weighted sample. ${ }^{25}$ The MSB is defined as the differences in covariate means as a percentage of the square root of the average sample

\footnotetext{
${ }^{22}$ We tested the sensitivity of our results by specifying more parsimonious models but found very little differences in the estimated effects.

${ }^{23}$ The predictive power of the respective models ranges closely around $70 \%$ for all models, see Table S.1 in the Appendix. Full estimation results are available on request.

${ }^{24}$ We investigate the robustness of our results with respect to the choice of the common support and potential outliers in the sensitivity analysis in Section 5.3.

${ }^{25}$ See Caliendo and Kopeinig (2008) for a more detailed discussion of matching quality issues.
} 
variances of the treatment and control group, whereby it is generally assumed that a MSB below $5 \%$ reflects a well-balanced covariate distribution in the sample. We control for 53 variables in our PS specification and find that around half of the variables are rejected to have equal means in a one-sided $5 \%$ significance $t$-test before weighting is conducted. After weighting, however, the same test finds for all programs that none of the variables has unequal means. Similarly encouraging results are obtained using the MSB as a criterion. Before weighting the MSB is around 20\%, but afterwards it is below $3 \%$ for all programs and time windows in East Germany and below $2 \%$ in the West. Overall, this indicates that reweighting yields a control group that is very similar to the treatment group with respect to their observable characteristics at point of entry into treatment. ${ }^{26}$

\section{Main Results and Sensitivity}

\section{$5.1 \quad$ Key Results}

As our primary outcome of interest we consider the integration in unsubsidized regular employment. ${ }^{27}$ Figures 3 (East Germany) and 4 (West Germany) plot the treatment effects on the employment probabilities during the 60 months following program entry. Monthly effects are calculated as the difference between treated and (weighted) control outcomes, which we also plot to facilitate interpretation. Additionally, we provide the cumulative effects of program participation after 30 and 60 months in Table 5. We focus on overall effects irrespective of timing of entry and address differences only if they are of interest.

\section{INSERT FiguRES 3 AND 4 ABOUT HERE.}

The monthly outcome plots reveal that except for JCS and PT measures, all programs significantly improve the labor market prospects of participants. Following initial lockingin and transition phases, the treatment impact stabilizes for all programs at around two years after program entry. The long-run impact of program participation - after the third year of program entry and onwards - amounts to a monthly employment boost between 5 to 20 percentage points, depending on program and region. We see that WS and JWS are the most successful programs in East Germany in the long-run (i.e. at the end of our observation period) with an average impact of 20 to 25 percentage points. Similarly, JWS is the most successful program in West Germany, with a 20 percentage point program impact, while here the effects of WS and FT are around 10 percentage points. The difference in relative impacts of wage subsidies and training measures in both regions seems to be in line with the notion, that West German program participants are more constraint by their adverse labor market characteristics than demand side restrictions. Hence, programs that aim at gradually enhancing labor market skills, i.e. long-term classroom training or long-term practical experience are more apt to overcome the entry barriers faced by West German youths.

\footnotetext{
${ }^{26}$ See Tables S.2 and S.3 in the Appendix for the detailed results of the $t$-test and the MSB.

${ }^{27}$ We only consider employment subject to social security contributions as a success. This excludes "marginal employment", i.e. jobs that pay only up to 400 Euro and entail reduced social security contributions from the employer.
} 
The labor market integration of participants in wage subsidies (JWS and WS) takes place in discontinuous jumps, suggesting an immediate integration into the labor market. As firms were required to offer a minimal period of unsubsidized employment following the subsidy, this is driven by the continuation of the employment relationship within the same firm. Even though we see a small decline in the employment probabilities when the employment guarantees expire, the overall employment levels of the treated remain remarkably high (between $45 \%$ to $60 \%$ ), such that wage subsidies can be seen as stepping stone into stable unsubsidized employment. In contrast to the immediate integration of participants in wage subsidies, participants in training measures (JS, STT and FT) experience a period of high intensity transitions into employment after the program has ended. This period lasts for about six to twelve months and can be seen as causal for the persistent employment gap between treated and non-treated individuals during the rest of the observation period. Training measures in the East perform similar independent of their duration - with a long-term employment impact of about 10 percentage points; whereas in the West short-term training (JS and STT) increases the employment probabilities of participants less than long-term training (FT). The effects for JS and STT have to be interpreted with caution, since a significant share of youths in the East (40\%) and West (27\%) participate in further ALMP programs. We address this issue in our sensitivity analysis in Section 5.3. In contrast to the previous programs, JCS and PT do not exhibit any positive long-term employment impact on program participants. In particular we find that participation in these programs decreases the probability of entering employment in the medium-run, even though the negative effect phases out to zero over the course of the observation period.

A further thing to note is that youths participating in longer-term measures experience severe locking-in effects during program participation - around 10 to 20 percentage points. If one interprets the level of locking-in during program participation as an initial investment, the cumulative benefit of program participation should be taken as measure for the net program effectiveness. The strength of locking-in depends on the opportunity costs of participation that are a function of, e.g., the program duration and the timing of entry into the program. Since non-participating youths experience particularly strong transitions out of unemployment during the first six months in their unemployment spell, this substantially aggravates the opportunity costs of entering the program during this phase. Table 5 presents the cumulative employment effects (30 and 60 months after program entry) overall and differentiated by entry strata.

\section{INSERT TABLES 5 AND 6 ABOUT HERE.}

Several issues emerge considering the employment outcomes: First, it can be seen that the relative cumulative long-run effectiveness of programs is largely consistent with the relative monthly long-run effectiveness. After 60 months, participants in wage subsidies yield the largest cumulative effects (up to nine months in East and five to nine months in West Germany). For the shorter programs JS and STT the cumulative effects are significantly positive between three and four months. For the longer FT measures, the effects are partly not significant after 30 months (due to long duration of the program), 
but turn positive after 60 months ( 3 and 4.5 months in East and West Germany). JCS and PT are the two programs with negative cumulative employment effects throughout. Second, we find that for almost all programs the cumulative effects are increasing with the timing of entry. In particular, we do not find significant differences in the monthly employment effects by entry time ${ }^{28}$, so that the high opportunity costs of an early entry largely drive these results. Compared to individuals entering in the first three months of their unemployment spell, the locking-in costs are significantly reduced for later program entries. The largest differences across entry strata occur for JWS in the West, with a six-months cumulative gap for the earliest and the latest entries after 60 months.

Even though the integration into regular employment is the primary outcome of interest, we also test whether programs increase the participation in further unsubsized education or training, i.e., apprenticeships or higher secondary/tertiary schooling. As the administrative data only records apprenticeship participation we use the filling procedure described already in Section 3.3 (further details in Appendix A.2). The monthly treatment effects on the probability to participate in unsubsidized education are depicted for participants in PT programs - predominantly aimed at integrating youths in unsubsidized education or professional training - in the lower right panel of Figures 3 and 4. For the other measures - which are aimed at integration into employment - the cumulative impacts on education participation are depicted in Table 6. It can be seen that PT measures do indeed significantly improve participation in education. After about one year after entry into the program, participants experience a stable positive increase in education probabilities of around 10 percentage points between month 12 to 48 . Coinciding with the approximate three-year duration of an apprenticeship in Germany this is indicative of successful completion of a professional training. Further evidence for the education success of PT measures is given by a descriptive analysis of the share of youths having obtained a professional qualification until the end of our observation period (i.e. at most 72 months after initial unemployment entry). As Table 7 reveals, the share of youths with a professional qualification increases by $20 \%$ in the East and $17 \%$ in the West for participants in contrast to $8 \%$ and $6 \%$ for non-participants. Again we find that the timing of program entry matters, as we observe an actual decline in effectiveness for later entries (see Table 6 ) in the West. Potentially driven by discouragement or rapid reduction in human capital for the rather young participants of $\mathrm{PT}$, the fast integration into education seems to be crucial in order to avoid negative long-term effects of unemployment.

Table 6 also shows that none of the programs aimed at integrating youths into the first labor market have a positive impact on the education probabilities. The descriptive comparison of professional training shares at entry into unemployment and 72 months later shows that the average level of professional training did not increase strongly (about $3 \%$ on average) for youths who participated in employment programs. For East Germany this is not surprising as youths exhibited above average shares of professional training already at program start. In the West, however, about one third of participating youths still do not have any type of professional training at the end of our observation period.

\footnotetext{
${ }^{28}$ Detailed monthly outcome plots by entry time into the program are available from the authors upon request.
} 
Again, youths participating in JCS fare much worse than the rest with about 40\% (75\%) of youths being without any professional degree after 72 months.

\subsection{Effect Heterogeneity}

In this section we inspect effect heterogeneity across gender and pretreatment schooling levels (below/equal vs. above lower secondary schooling certificate). To account for potential differences in the timing and nature of selection into treatment and to ensure that we only compare treated and non-treated within the region of common support we repeat the estimation procedure outlined in Section 3 for each of the respective subgroups. This leaves us with 14 distinct program-subgroup cells in East and West Germany (compare Table S.4 in Appendix ?? for details). ${ }^{29}$ What should be kept in mind is that the separation of the analysis for the respective subgroups entails that the results are not directly comparable. For example, a higher level in the estimated effects for women does not indicate that the program is more beneficial for women than it is for men, but that women have a higher benefit compared to non-participating women than men have compared to non-participating men. In Appendix ?? we present selected monthly treatment effects estimates on the employment probabilities in Tables S.5 (gender) and S.7 (schooling levels); cumulative effects on employment and education outcomes can be found in Tables S.6 and S.8.

Effects by Gender: Our estimates reveal very minor differences in the monthly employment effects across gender. Only the long-run persistency of effects appears to differ for some programs. In East Germany we find for all programs except PT, that two to three years after program entry the average monthly treatment impact of women declines substantially and then stabilizes again at a lower (but positive) level towards the end of the observation period. In the West we find a similar, but less pronounced long-term reduction in treatment effects for female participants in STT, JS and WS. This is potentially explained by an increased labor force attachment among women with a successful program participation, who delay their timing of fertility in order to remain in the labor force (compare Lechner and Wiehler, 2011, for similar results on ALMP in Austria). Examples on short-to medium-run differences between young men and women occur for participants in WS, and training measures in the West. For the case of WS we find that after an initially similar program impact, the employment probabilities of men in East and women in the West decline substantially during the 12 months following program participation, while they remain stable for the other groups. These differences are most likely driven by differences in take-over probabilities of the firm receiving the subsidy, the cause of which would however require a more in-depth analysis of firm and participant characteristics. In the case of STT and FT measures in the West we find that women seem to benefit much less from STT measures than men (the cumulated effect only amounts to 1.5 months), but benefit more from longer-term training in FT. The latter finding is in line

\footnotetext{
${ }^{29}$ Due to the small number of observations within some cells, we modify the original PS specification on a case-by-case basis by successively excluding covariates with low explanatory value to obtain the optimal specification in terms of correct predictions rates. Full estimations results and further details are available upon request.
} 
with the observation that young women generally perform better in school-based training than young men - a validation would require a direct comparison of the subgroups however.

Effects by Schooling Levels: Youths with different levels of pretreatment schooling have different returns to program participation. By and large these differences can be summarized into programs being more effective for high-skilled youths in terms of employment outcomes. In particular we find that participants in WS, JS, STT and FT with high levels of pretreatment schooling spend on average six months longer in employment than their non-treated counterparts over the whole observation period-compared to three months for youths with low schooling levels (Table S.7). We also observe that the periods of locking-in go beyond the median program duration for youths with a low schooling degree, which would correspond to further program enrollment. In the case of a successful further participation, the true gap in program success for youths with low and high pretreatment schooling in the first program is expected to be even larger. An exception from these differential effects is given by JWS and JCS measures, which seem to be equally beneficial (detrimental) in terms of employment outcomes. The program effect of participation in JCS is either zero or slightly negative for both subgroups, while all youths participating in JWS have a cumulative employment gain of eight to ten months. As such the finding on JWS is an encouraging deviation from the our earlier findings as it is also driven by similar long-run effects, and not solely by the leveling of locking-in and program effects. In terms of education outcomes for participants in PT measures (last two rows of Table S.7), we also observe that youths with higher schooling levels experience higher rates of education participation between month 12 to 36 .

\subsection{Sensitivity Analysis}

We test the sensitivity of our results with respect to the crucial assumptions made in the main analysis. First, we consider the problem of further program participation and investigate to what extent our treatment estimates of the first participation in JS and STT measures are driven by participation in further measures. Second, we apply a dynamic evaluation approach that changes the composition of the control group. Finally, we check whether different variants of imposing common support alter our results. Table S.9 presents the estimated cumulative employment effects from the sensitivity analysis together with the results obtained in the main analysis as a reference. ${ }^{30}$

Further Program Participation: We have noted in Section 5.1 that the effects for JS and STT have to be interpreted with caution, since a significant share of youths in participate in further ALMP programs. To be more specific, $44 \%$ (31\%) of the JS participants in East (West) Germany participate in a further ALMP program within one year and the same is true for $38 \%$ (24\%) of the participants in STT. As only individuals for whom the program did not lead to an entry into employment are assigned to further programs, the effectiveness of the initial measures would require the consideration of fully dynamic selection effects, which is beyond the scope of this paper (see Lechner and Miquel, 2010,

\footnotetext{
${ }^{30}$ Results on education probabilities are not presented separately as their sensitivity is very similar to employment outcomes. But they are available upon request.
} 
for an estimation approach). Instead we assess the sensitivity of our findings by restricting the sample of treated to individuals who participate in only one program during the first twelve months of their unemployment spell. This is insightful as it provides an indication whether any of the positive employment effects are attributable to participation in the initial program. As we exclude only youths for whom the program was unsuccessful, our sensitivity estimates are likely to be more positive than for the average participant. The results in Table S.9 show that the new results are very similar to the results from the main analysis. To be on the safe side we repeated this exercise not only for participants in JS and STT but also for the other programs (where the probabilities of subsequent participation is much lower). The medium- and long-run cumulative effects are very similar to the reference estimates for all programs; none of the cumulative effects after 60 months in the sensitivity analysis differs significantly from the main results.

Dynamic Evaluation Approach: We assess the sensitivity of our results with respect to the choice of the evaluation approach and re-estimate our results using a dynamic approach, as outlined in Section 3.2. We hence redefine our control group to include youths who participate at any point in time later during their unemployment spell and who potentially participate in other programs. We find that the point estimates are slightly increased or reduced using the dynamic approach (compare Table S.9), but none of these changes are significant at a conventional level. The observed increase in effects for the majority of programs is most likely due to controls entering other programs under investigation. As they experience periods of locking-in themselves, the opportunity cost of participating in the program of investigation is reduced. Given the large size of our never-treated control group, all of the observed changes are only minor and insignificant. We hence conclude that the choice of the evaluation approach has no significant implications for our results and using the dynamic approach does not change the overall evidence on program effectiveness.

Alternative imposition of Common Support: A necessary condition for the identification of treatment effects is the existence of corresponding non-participants over the whole support of the treated PS distribution, where limited overlap may be particularly distorting when using IPW (as pointed out by Frölich, 2004). We chose the "Min-Max"condition in Section 4.3, but several alternatives have been suggested. Black and Smith (2004) argue that the imposition of a more restrictive trimming of the PS distribution might be beneficial if treated (controls) with very low (high) values of the PS are more likely to suffer from measurement error in the treatment variable, and remaining unobserved factors are more important here. To assess the sensitivity of our results with respect to this issue we conduct several robustness tests. First, we exclude control observations with very large values of the PS (above the 99 percentile). Second, we exclude areas of the distribution where there is only low overlap between treated and controls and restrict the common support to an "optimal" area defined by $\alpha \leq P(W) \leq 1-\alpha$, whereby $\alpha$ is chosen to balance two opposing variance components (as suggested by Crump, Hotz, Imbens, and Mitnik, 2009). While the variance of the estimate increases due to the lower number of observations, it decreases with an improved level of overlap between treated 
and non-treated. ${ }^{31}$ Finally, we restrict the propensity score distribution even more, by dividing the distribution into twenty equidistant percentiles and estimate the effects only in regions where we have at least $5 \%$ of treated and non-treated observations. Clearly, restricting the estimation to areas of "thick support" reduces the validity of the results and might potentially lead to changes in estimated effects. This has the drawback that it is unclear whether changes are due to effect heterogeneity, large weights of outliers, or unobserved heterogeneity in characteristics. The results in Table S.9 show that our effect estimates hardly change. This confirms our expectations discussed in Section 4.1, namely that due to a large sample of non-participants and a restrictive common support condition ("Min-Max" cut off rule) this issue is of minor relevance in our case.

\section{Conclusion}

Plagued with a persistent problem of long-term unemployment among youths, Germany is one of the European countries with the highest expenditures on youth ALMP - at 1.7 billion euros per year between 1999 and 2002. Between 2000 and 2010 about 1.4 million youths entries into ALMP were recorded each year - and the number is increasing. This evaluation study provides the first comprehensive assessment of the short-to-long-term employment impact of participation in various ALMP programs in place.

Based on a representative sample on young unemployment entries in 2002, we investigate the effectiveness of program participation vs. non-participation using an quasiexperimental estimation approach with IPW. Analyzing a broad range of instruments that belong to the common set of policy tools employed in European countries, we add to the previous European evaluation literature dealing with youth ALMP. We conduct the analysis separately for youths in East and West Germany, shedding some light on the effectiveness of the respective measures to improve the employment situation of youths under differential social, economic and labor market conditions.

In terms of improving the employment probabilities of unemployed youths, the overall picture of the different ALMP analyzed is rather positive, indicating a persistent and stable employment effect. In particular, we find a significant increase in employment probabilities of participating youths for almost all measures examined. Focusing on the long-term employment impact, the strongest effects are observed for participants in wage subsidies (10 to 20 percentage points); job search assistance, short- and longer term training measures yield smaller but also persistently positive effects ( 5 to 10 percentage points). With respect to education outcomes we find that preparatory programs aimed at integrating youths into an apprenticeship are successful in doing so. In contrast to the aforementioned beneficial employment programs, public sector job creation schemes (JCS) are found to be harmful for the employment prospects of participants in the short- to medium-run and ineffective in the long-run. Put more drastically, if one considers the initial program participation as investment into future labor market outcome, the return of participating in JCS is negative throughout the whole observation period of five years. This is consistent

\footnotetext{
${ }^{31}$ The implementation of this is done using the STATA tool optselect.ado provided by the Crump, Hotz, Imbens, and Mitnik (2009).
} 
with previous evaluation results for other countries that show the ineffectiveness of JCS for youths (compare, e.g., Dorsett, 2006, for the "environmental task force" implemented in the New Deal for Young People in the UK), and for the adult population (compare, e.g., Caliendo, Hujer, and Thomsen, 2008). Against these overwhelmingly negative findings for JCS it is surprising that during the current economic crisis policy makers still consider the temporary extension of these measure to counteract soaring levels of youth (long-term) unemployment rates (compare OECD, 2011).

In terms of a differential impact of the respective measures under different labor market conditions, our analysis provides evidence from the comparison of the employment impact for program participants in East and West Germany. For all measures we find similar qualitative results, suggesting that the programs can be sufficiently adapted to benefit in either type of economic environment. However, we also find that the relative benefit of longer-term training measures (FT) compared to wage subsidies (WS) seems to be higher in the West than in the East, which needs to be interpreted with the significantly lower pretreatment education levels of West German youths in mind. While youths in the East are characterized by high initial schooling levels, the provision of work experience by removing demand-side barriers seems to be the most important hurdle to integrating into the labor market. In contrast, youths in the West have much less favorable labor market characteristics and hence seem to benefit more from an improvement in human capital endowment. Further evidence for this is given by our finding that only youths with high schooling levels in the West experience a positive long-term employment impact of participation in preparatory training. For youths in the East, the acquisition of a professional degree might not be sufficient to protect them from struggling at the "second barrier".

Recent statistics on youth unemployment levels in Germany (and similarly in other European countries) show that the probability to enter unemployment is significantly higher for low-educated than medium-educated youths, with a steadily increasing gap. Together with the expected shortage of labor in the medium-run the by far most vulnerable labor market group will be low-educated youths, making them the most important target of policy intervention. Our analysis provides evidence however, that the these youths are not sufficiently accommodated in the current policy set-up. In particular we find that all programs except JWS improve the labor market prospects of youths with high levels of pretreatment schooling to a greater extent than that of youths with low levels of pretreatment schooling. This suggests an insufficient adjustment of the respective measures for the requirements of unskilled youths. We further find that youths who are assigned to the most successful employment measures within the first twelve months in unemployment, compared to later- or never-participants, have much better characteristics in terms of their pre-treatment employment chances. As the program assignment process is likely to favor individuals for whom the measures are most beneficial, the observed strong positive selection of youths into ALMP - in particular in the East - supports our interpretation of a systematic lack of ALMP alternatives that could benefit low-educated youths.

Our analysis also indicates potential avenues for the improvement of ALMP for low educated youths. So far, none of the programs aimed at labor market integration increases the education participation of youths. By readjusting existing labor market programs to 
accommodate participation in further education or training as intermediate objective, the integration of low-educated youths into the labor market could be done in a more sustainable manner. Secondly, we find that wage subsidies of shorter duration work better for high-schooling youths, while wage subsidies with longer duration work equally well for low and high educated youths. This suggests that low educated youths require more time to turn the subsidized work experience into a stepping stone to a stable employment entry. By extending the access to longer-term professional experience for these youths, an additional barrier of labor market integration for these could potentially be removed. 


\section{References}

Abbring, J. H., And G. J. VAN DEN Berg (2003): "The Nonparametric Identification of Treatment Effects in Duration Models," Econometrica, 71(5), 1491-1517.

(2004): "Analyzing the Effect of Dynamically Assigned Treatments Using Duration Models, Binary Treatment Models, and Panel Data Models," Empirical Economics, $29,5-20$.

Autorengruppe Bildungsberichterstattung (2006): 1. Bildungsbericht - Bildung in Deutschland. Ein indikatorengestützter Bericht mit einer Analyse zu Bildung und Migration. Ständige Konferenz der Kultusminister der Länder in der Bundesrepublik Deutschland und BMBF.

Bell, D. N., and D. G. Blanchflower (2010): "Youth Unemployment: Déjà Vu?," IZA Discussion Papers 4705, Institute for the Study of Labor (IZA).

Black, D. A., And J. A. Smith (2004): "How robust is the evidence on the effects of college quality? Evidence from matching," Journal of Econometrics, 121(1-2), 99-124.

Brodaty, T., B. Crépon, and D. Fougère (2001): "Using Matching Estimators to Evaluate Alternative Youth Employment Programs: Evidence from France, 1986-1988," in Econometric Evaluation of Labour Market Policies, ed. by M. L. und Friedhelm Pfeiffer, no. 13 in ZEW Economic Studies. Physica-Verlag.

Bundesministerium für Arbeit und Soziales/Bundesministerium für Bildung UND Forschung (1999): "Eckpunkte für ein Sofortprogramm zum Abbau der Jugendarbeitslosigkeit," Discussion paper, In: Chronik er Artbeitsmarktpolitik, IAB.

Bundesministerium FÜR BILdUng UND Forschung (2009): Datenreport zum Berufsbildungsbericht 2009 - Informationen und Analysen zur Entwicklung der beruflichen Bildung. Bundesinstitut für Berufsbildung.

Burgess, S., C. Propper, H. Rees, and A. Shearer (2003): "The class of 1981: the effects of arly career unemployment on subsequent unemployment experiences," Labour Economics, 10(3), 291-309.

Busso, M., J. DiNardo, and J. McCrary (2009): "New Evidence on the Finite Sample Properties of Propensity Score Matching and Reweighting Estimators," Discussion Paper 3998, IZA, Bonn.

Caliendo, M., A. Falk, L. C. Kaiser, H. Schneider, A. Uhlendorff, G. J. VAN DEN Berg, AND K. F. Zimmermann (2011): "The IZA Evaluation Dataset: towards evidence-based labor policy making," International Journal of Manpower, 32(7), $731-752$.

Caliendo, M., and R. Hujer (2006): "The Microeconometric Estimation of Treatment Effects - An Overview," Allgemeines Statistisches Archiv, 90(1), 197-212.

Caliendo, M., R. Hujer, and S. L. Thomsen (2008): "The Employment Effects of Job Creation Schemes in Germany: A Microeconometric Evaluation," in Advances in Econometrics, ed. by D. Millimet, J. Smith, and E. Vytlacil, vol. Volume 21: Estimating and Evaluating Treatment Effects in Econometrics. Emerald Group Publishing Limited.

Caliendo, M., and S. Kopeinig (2008): "Some Practical Guidance for the Implementation of Propensity Score Matching," Journal of Economic Surveys, 22(1), 31-72.

Caliendo, M., And R. Schmidl (2011): "Youth Unemployment and ALMP in Europe," mimeo. 
Centeno, L., M. Centeno, and Á. A. Novo (2009): "Evaluating job-search programs for old and young individuals: Heterogeneous impact on unemployment duration," Labour Economics, 16(1), 12-25.

Crump, R. K., V. J. Hotz, G. W. Imbens, and O. A. Mitnik (2009): "Dealing with limited overlap in estimation of average treatment effects," Biometrika, 96(1), 187-199.

Dehejia, R. H., and S. Wahba (1999): "Causal Effects in Nonexperimental Studies: Reevaluating the Evaluation of Training Programs," Journal of the American Statistical Association, 94(448), 1053-1062.

Dietrich, H. (2001): "Wege aus der Jugendarbeitslosigkeit - Von der Arbeitslosigkeit in die Maßnahme?," Mitteilungen aus der Arbeitsmarkt und Berufsforschung, 34(4), 419-439.

Dornette, J., And M. JACOB (2006): "Zielgruppenerreichung und Teilnehmerstruktur des Jugendsofortprogramms," IAB Forschungsbericht , 16, 3-48.

Dorsett, R. (2006): "The new deal for young people: effect on the labor market status of young men," Labor Economics, 13, 405-422.

Ehlert, C., J. Kluve, and S. . Schaffner (2010): "The impact of ZACQ: Individually designed assistance for disadvantaged ysouths," mimeo.

Ellwood, D. T. (1983): "Teenage Unemployment: Permanent Scars or Temporary Blemishes?," NBER Working Papers 0399, National Bureau of Economic Research, Inc.

Fitzenberger, B., And S. Speckesser (2007): "Employment Effects of the Provision of Specific Professional Skills and Techniques in Germany," Empirical Economics, 32(2-3), 529-573.

Fredriksson, P., And P. Johansson (2002): "Program evaluation and random program starts," IFAU Working Paper Series 2003:1, Institute for Labour Market Policy Evaluation (IFAU).

Fredriksson, P., And P. Johansson (2008): "Dynamic Treatment Assignment: The Consequences for Evaluations Using Observational Data," Journal of Business and Economic Statistics, 26(4), 435-445.

FrÖLICH, M. (2004): "Finite-Sample Properties of Propensity-Score Matching and Weighting Estimators," The Review of Economics and Statistics, 86(1), 77-90.

Goldsmith, A., J. Veum, And W. DARITy (1997): "Unemployment, joblessness, psychological well-being and self-esteem: Theory and evidence," The Journal of Socio-Economics, 26, 133-158(26).

GregG, P., And E. Tominey (2005): "The wage scar from male youth unemployment," Labour Economics, 12(4), 487-509.

Huber, M., M. Lechner, and C. Wunsch (2010): "How to Control for Many Covariates? Reliable Estimators Based on the Propensity Score," IZA Discussion Paper 5268, Institut for the Study of Labor (IZA).

Imbens, G. (2000): "The Role of the Propensity Score in Estimating Dose-Response Functions," Biometrika, 87(3), 706-710.

Imbens, G. (2004): "Nonparametric Estimation of Average Treatment Effects under Exogeneity: A Review," The Review of Economics and Statistics, 86(1), 4-29. 
Imbens, G., And J. Wooldridge (2009): "Recent Developments in the Econometrics of Program Evaluation," Journal of Economic Literature, 47(1), 5-86.

JACOBI, L., AND J. KLuve (2007): "Before and after the Hartz reforms: The performance of active labour market policy in Germany," Zeitschrift für ArbeitsmarktForschung, 40, H. 1, 45-64.

KorPi, T. (1997): "Is Utility related to Employment Status? Employment, Unemployment, Labor Market Policies and Subjective Well-Being among Swedish Youth," Labour Economics, 4(2), $125-147$.

Kultusministerkonferenz Germany and the EURIDYCE Unit (2009): "The Education System in the Federal Republic of Germany 2007," Discussion paper, Kultusministerkonferenz Germany and the EURIDYCE Unit in the Bundesministerium für Forschung und Bildung, In cooperation with the German EURYDICE Unit of the Federal Government in the Federal Ministry of Education and Research.

LARrson, L. (2003): "Evaluation of Swedish Youth Labor Market Programs," The Journal of Human Resources, 38, 4, 891-927.

LECHNER, M., AND R. Miquel (2010): "Identification of the effects of dynamic treatments by sequential conditional independence assumptions," Empirical Economics, 39(1), 111137.

Lechner, M., R. Miquel, and C. Wunsch (2011): "Long-run Effects of Public Sector Sponsored Training in West Germany," Journal of the European Economic Association, $9(4), 742-784$.

LEChNeR, M., AND S. WieHLER (2011): "Kids or courses? Gender differences in the effects of active labor market policies," Journal of Population Economics, 24, 783-812.

Lechner, M., And C. Wunsch (2011): "Sensitivity of Matching-Based Program Evaluations to the Availability of Control Variables," Discussion Paper 5553, IZA.

NEUmann, M., J. Schmid, AND D. WERner (2010): Die Integration Jungendlicher in Ausbildung und Beschäftigung. Institut der deutschen Wirtschaft Köln.

OECD (2004): Employment Outlook. OECD Publishing, Paris. (2011): Employment Outlook. OECD Publishing, Paris.

Quintini, G., J. P. Martin, and S. Martin (2007): "The Changing Nature of the School-to-Work Transition Process in OECD Countries," IZA Discussion Papers 2582, Institute for the Study of Labor (IZA).

Reinberg, A., And M. Hummel (2005): "Höhere Bildung schützt auch in der Krise vor Arbeitslosigkeit," IAB Kurzbericht, 9, 1-6.

Rosenbaum, P., and D. Rubin (1983): "The Central Role of the Propensity Score in Observational Studies for Causal Effects," Biometrika, 70(1), 41-50.

Roy, A. (1951): "Some thoughts on the distribution of earnings," Oxford Economic Papers, 3(2), 135-146.

Rubin, D. B. (1974): "Estimating Causal Effects of Treatment in Randomized and Nonrandomized Studies," Journal of Educational Policy, 66, 688-701.

SiAnEsi, B. (2004): "An Evaluation of the Swedish System of Active Labour Market Programmes in the 1990s," The Review of Economics and Statistics, 86(1), 133-155. 
Smith, J., And P. Todd (2005): "Does Matching Overcome LaLonde's Critique of Nonexperimental Estimators?," Journal of Econometrics, 125(1-2), 305-353.

Verick, S. (2011): "Who is Hit Hardest during a Financial Crisis? The Vulnerability of Young Men and Women to Unemployment in an Econonomic Downturn," in From the Great Recession to Labour Market Recovery: Issues, Evidence and Policy Options, ed. by I. Islam, and S. Verick. ILO/Palgrave Macmillan. 


\section{Figures and Tables}

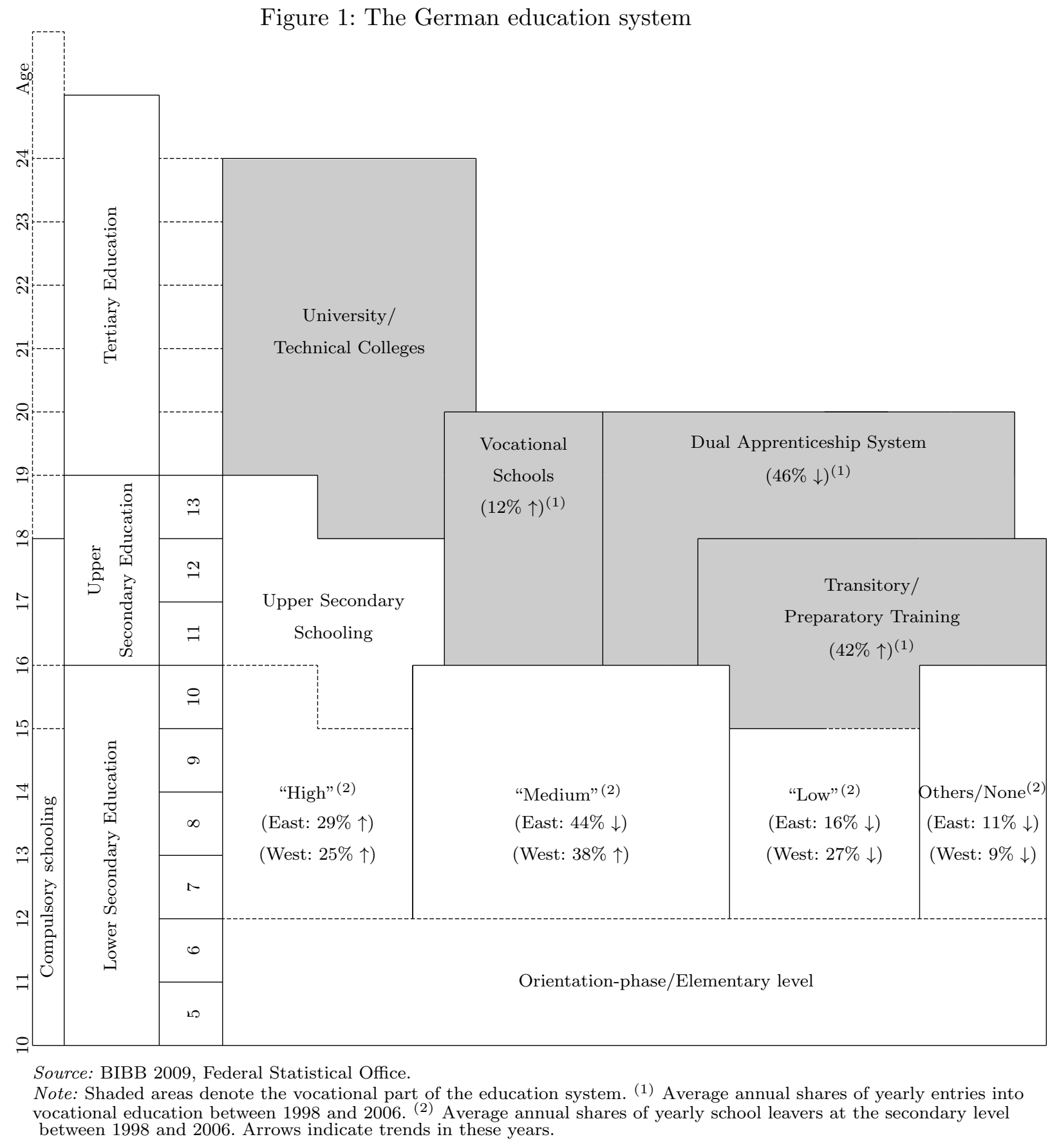


Figure 2: Unemployment and long-term unemployment youth-adult ratios, and GDP growth rates in Germany between 2000 and 2009

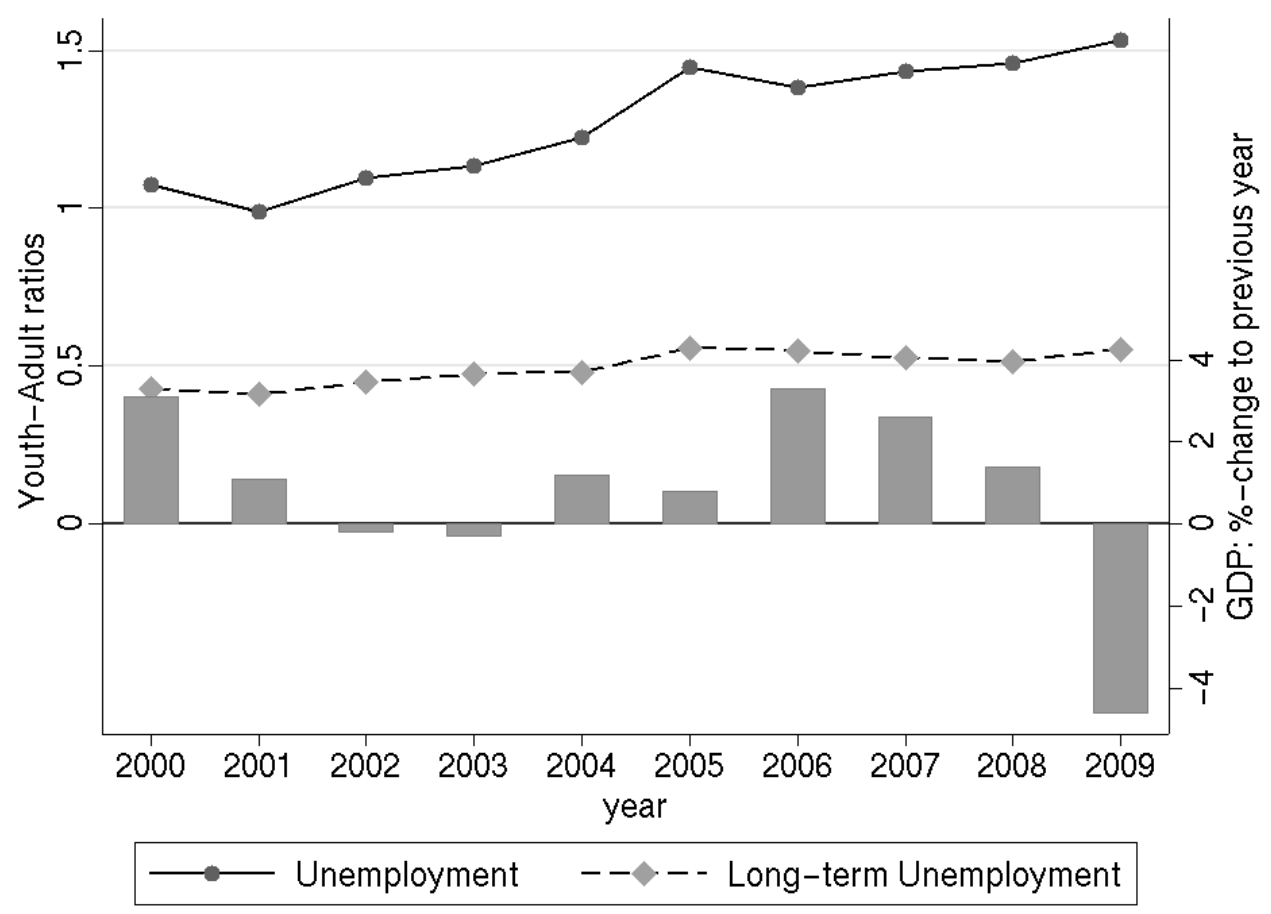

Source: Federal Statistical Office; Statistics of the Federal Employment Agency 
Figure 3: Causal effects of program participation in East Germany over time aggregate results over all program entries.

JS on Employment

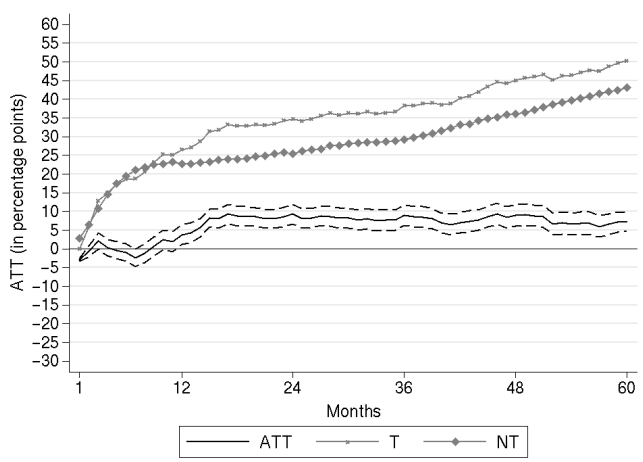

JWS on Employment

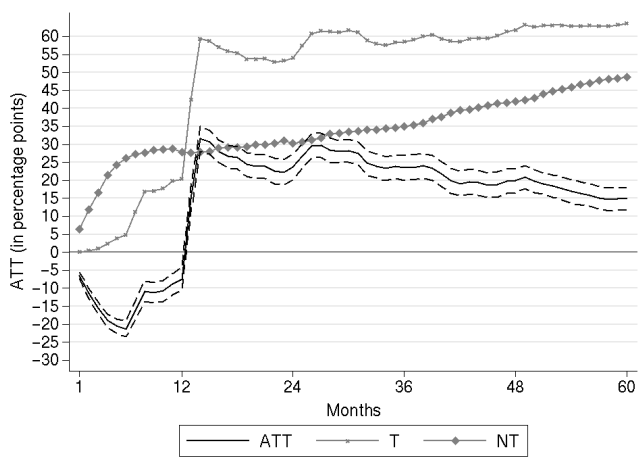

JCS on Employment

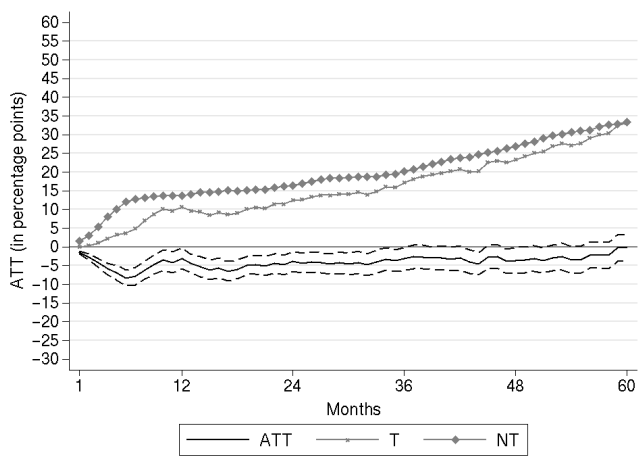

PT on Employment

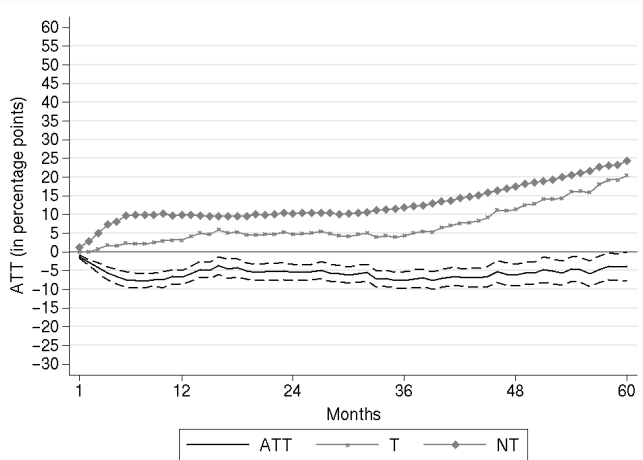

STT on Employment

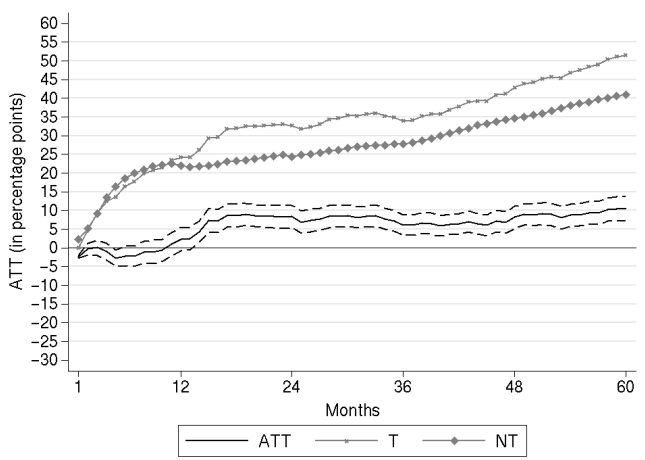

WS on Employment

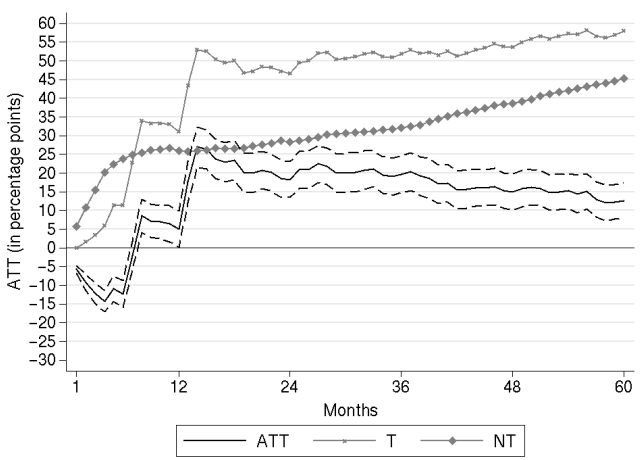

FT on Employment

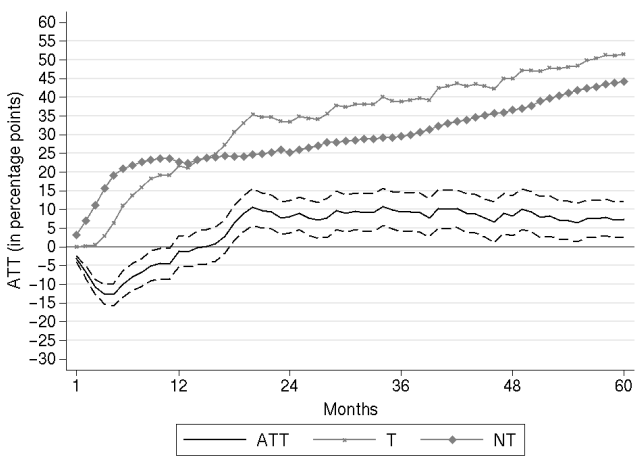

PT on Education

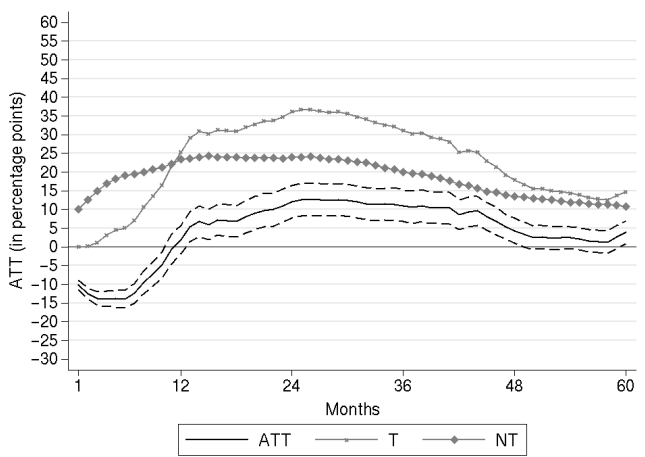

Note: The black solid line depicts the average treatment effects on the treated (ATT) - the dashed black line provides the $95 \%$ confidence-band based on bootstrapping with 200 replications. The ATT is the difference between the average monthly outcomes of the treated $(\mathrm{T})$ and the weighted average outcomes of the non-treated (NT) - the corresponding valuess are shown in gray. 
Figure 4: Causal effects of program participation in West Germany over timeaggregate results over all program entries

JS on Employment

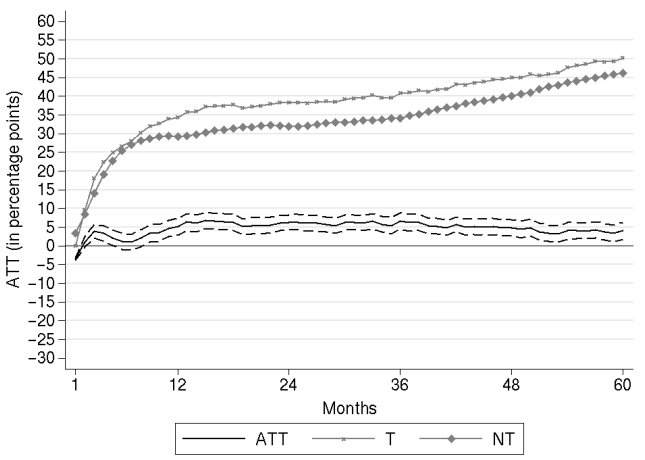

JWS on Employment

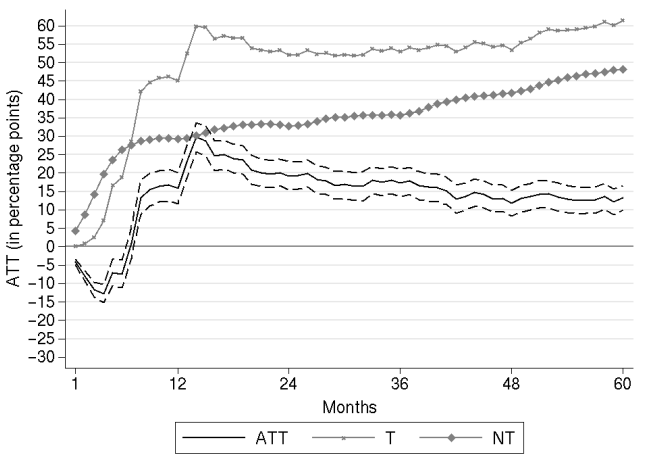

JCS on Employment

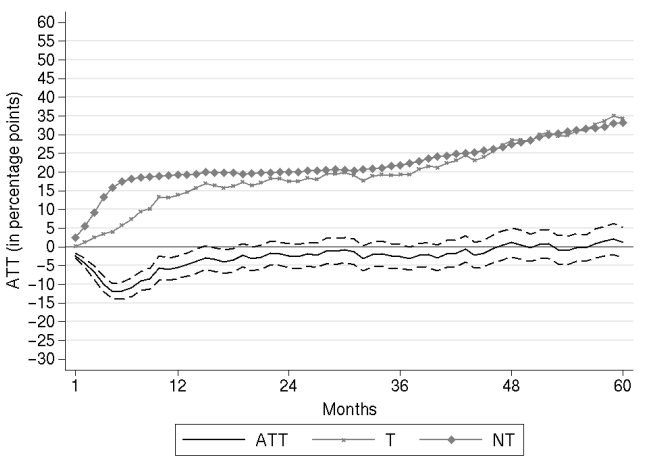

PT on Employment

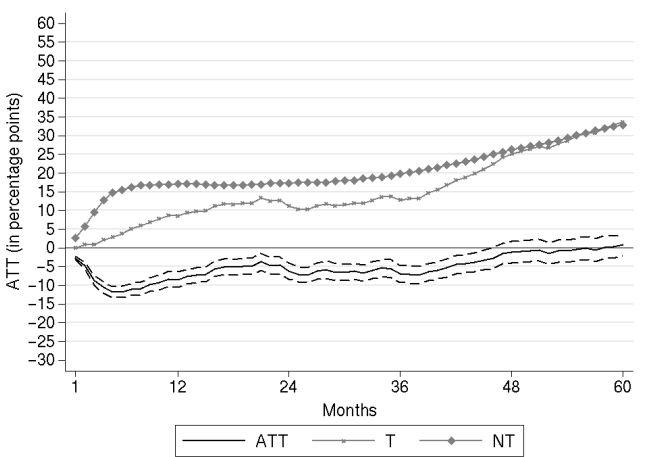

STT on Employment

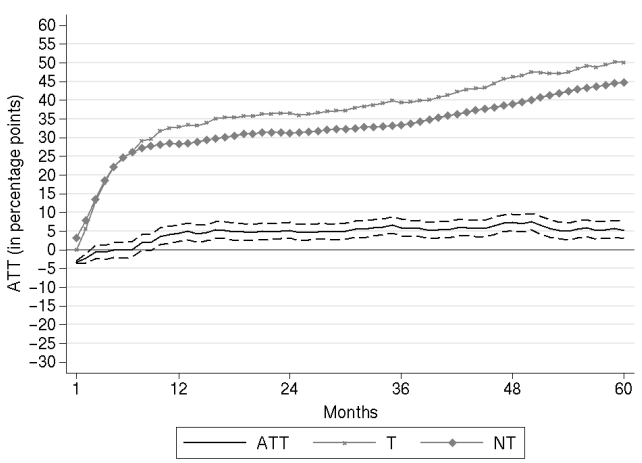

WS on Employment

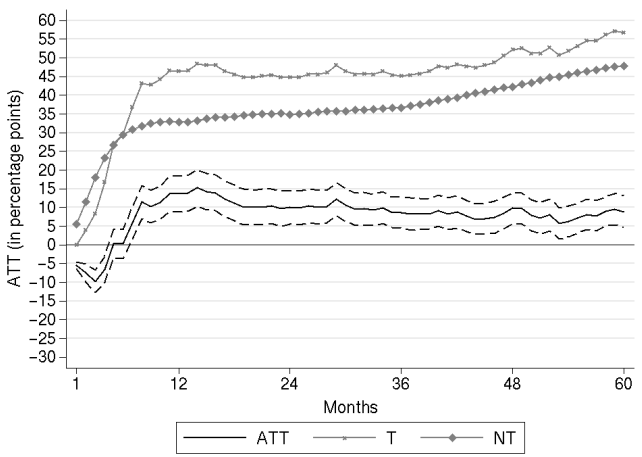

FT on Employment

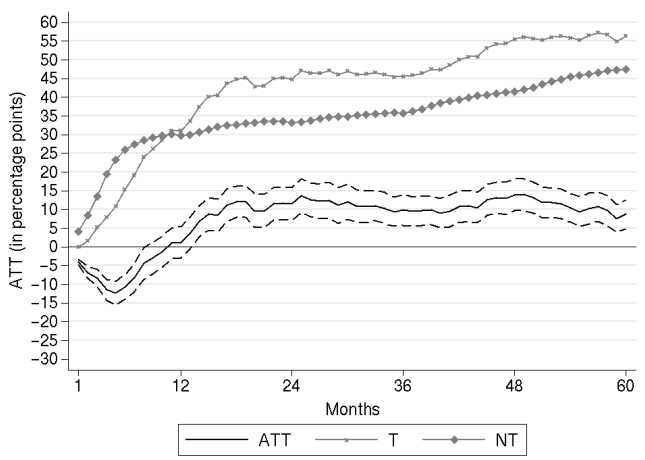

PT on Education

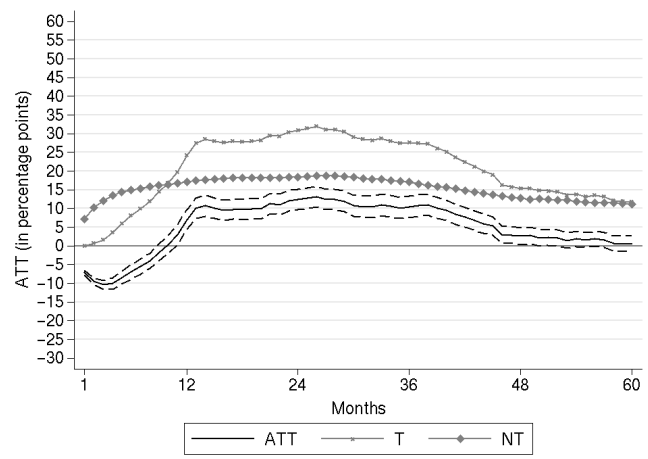

Note: The black solid line depicts the average treatment effects on the treated (ATT) - the dashed black line provides the $95 \%$ confidence-band based on bootstrapping with 200 replications. The ATT is the difference between the average monthly outcomes of the treated $(\mathrm{T})$ and the weighted average outcomes of the non-treated (NT) - the corresponding values gge shown in gray. 


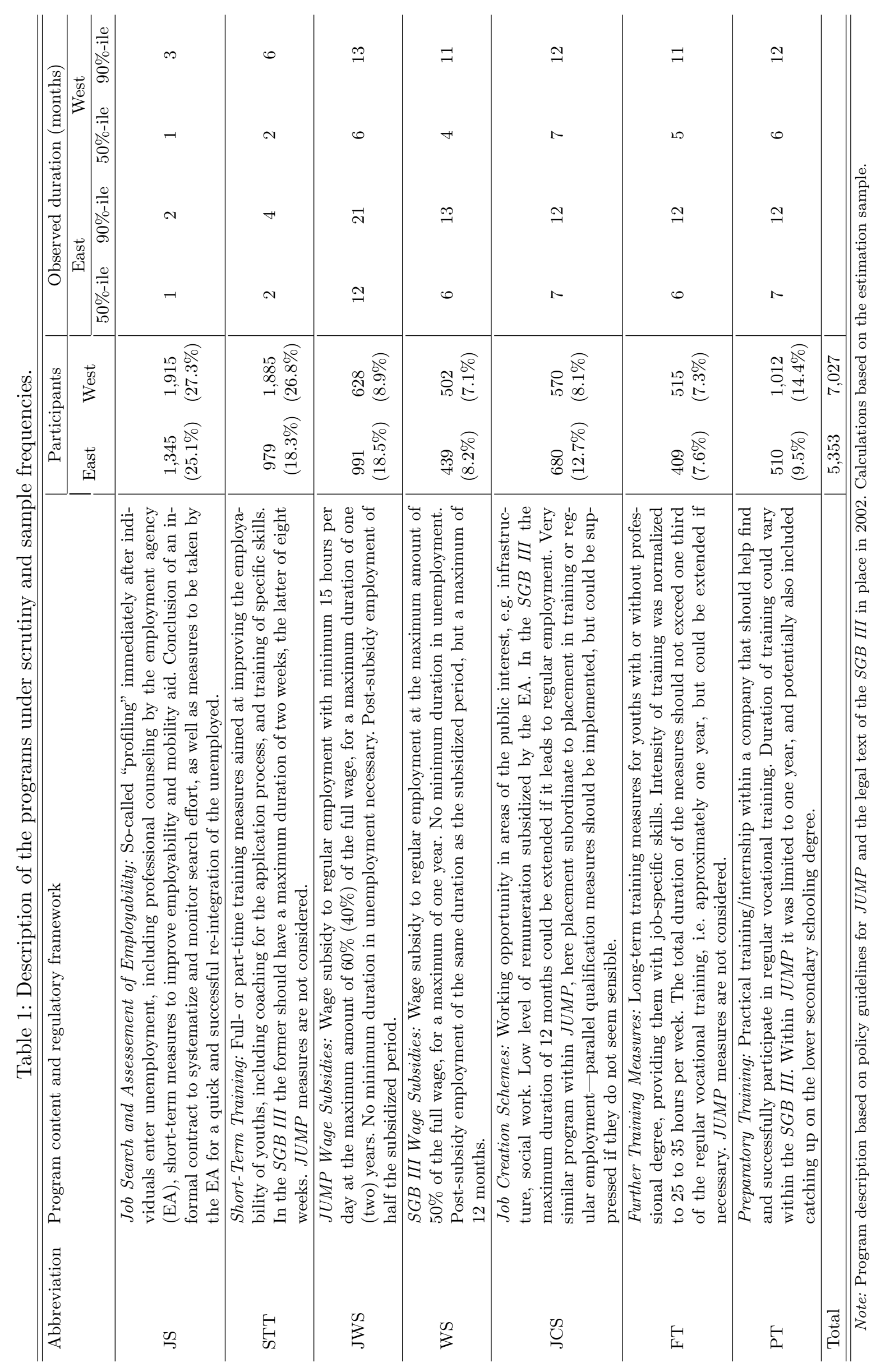


Table 2: Selected descriptive statistics of participants and non-participants

\begin{tabular}{|c|c|c|c|c|c|c|c|c|}
\hline \multicolumn{9}{|c|}{ East Germany } \\
\hline & JS & STT & JWS & $\overline{\mathrm{WS}}$ & JSC & $\overline{\mathrm{FT}}$ & $\overline{\mathrm{PT}}$ & NP \\
\hline Gender (Female) & 0.37 & 0.42 & 0.42 & 0.40 & 0.30 & 0.31 & 0.41 & 0.39 \\
\hline Age (above 20 years) & 0.72 & 0.73 & 0.71 & 0.72 & 0.66 & 0.77 & 0.27 & 0.56 \\
\hline Migration status & 0.02 & 0.09 & 0.01 & 0.04 & 0.03 & 0.02 & 0.07 & 0.05 \\
\hline Having children & 0.05 & 0.08 & 0.05 & 0.05 & 0.08 & 0.07 & 0.07 & 0.05 \\
\hline Health restrictions & 0.10 & 0.08 & 0.04 & 0.06 & 0.17 & 0.05 & 0.09 & 0.07 \\
\hline \multicolumn{9}{|l|}{ School leaving certificate } \\
\hline None & 0.06 & 0.05 & 0.01 & 0.03 & 0.14 & 0.05 & 0.19 & 0.07 \\
\hline Lower secondary school & 0.37 & 0.30 & 0.23 & 0.26 & 0.47 & 0.30 & 0.44 & 0.25 \\
\hline Middle secondary school & 0.52 & 0.56 & 0.65 & 0.59 & 0.36 & 0.58 & 0.32 & 0.44 \\
\hline Upper/specialized secondary School & 0.06 & 0.08 & 0.10 & 0.11 & 0.03 & 0.07 & 0.06 & 0.24 \\
\hline \multicolumn{9}{|l|}{ Professional training } \\
\hline None & 0.23 & 0.29 & 0.13 & 0.22 & 0.47 & 0.17 & 0.89 & 0.52 \\
\hline Apprenticeship/university & 0.77 & 0.71 & 0.87 & 0.78 & 0.53 & 0.83 & 0.11 & 0.48 \\
\hline \multicolumn{9}{|c|}{ During the last three years before unemployment entry, months spent in ... } \\
\hline regular employment & 18.26 & 15.05 & 21.06 & 18.84 & 13.00 & 16.44 & 3.69 & 11.69 \\
\hline ALMP & 4.42 & 4.41 & 3.24 & 3.64 & 5.17 & 5.10 & 3.47 & 2.71 \\
\hline inactivity & 8.02 & 11.64 & 7.70 & 8.72 & 11.38 & 9.18 & 24.06 & 16.54 \\
\hline unemployment & 5.76 & 5.24 & 4.12 & 4.98 & 6.85 & 6.18 & 3.99 & 3.99 \\
\hline \multicolumn{9}{|c|}{ Last activity before entry into unemployment } \\
\hline Regular employment & 0.63 & 0.59 & 0.62 & 0.56 & 0.58 & 0.64 & 0.40 & 0.54 \\
\hline Education, training, never employed & 0.28 & 0.34 & 0.34 & 0.36 & 0.31 & 0.28 & 0.40 & 0.36 \\
\hline Other & 0.08 & 0.07 & 0.05 & 0.08 & 0.12 & 0.07 & 0.20 & 0.10 \\
\hline Number of placement propositions & 4.77 & 3.95 & 3.27 & 3.24 & 3.45 & 3.93 & 0.93 & 1.89 \\
\hline \multicolumn{9}{|c|}{ West Germany } \\
\hline & $\overline{\mathrm{JSS}}$ & STT & JWS & $\overline{\mathrm{WS}}$ & JSC & $\overline{\mathrm{FT}}$ & $\overline{\mathrm{PT}}$ & $\overline{\mathrm{NP}}$ \\
\hline Gender (Female) & 0.36 & 0.38 & 0.34 & 0.36 & 0.30 & 0.33 & 0.38 & 0.39 \\
\hline Age (above 20 years) & 0.72 & 0.70 & 0.73 & 0.77 & 0.48 & 0.81 & 0.29 & 0.61 \\
\hline Migration status & 0.16 & 0.27 & 0.13 & 0.19 & 0.17 & 0.16 & 0.19 & 0.16 \\
\hline Having children & 0.05 & 0.06 & 0.05 & 0.06 & 0.03 & 0.06 & 0.03 & 0.05 \\
\hline Health restrictions & 0.08 & 0.07 & 0.06 & 0.07 & 0.08 & 0.08 & 0.06 & 0.07 \\
\hline \multicolumn{9}{|l|}{ School leaving certificate } \\
\hline None & 0.13 & 0.12 & 0.09 & 0.10 & 0.31 & 0.10 & 0.23 & 0.13 \\
\hline Lower secondary school & 0.50 & 0.49 & 0.50 & 0.52 & 0.55 & 0.50 & 0.52 & 0.44 \\
\hline Middle secondary school & 0.29 & 0.31 & 0.33 & 0.29 & 0.12 & 0.34 & 0.21 & 0.28 \\
\hline Upper/specialized secondary School & 0.08 & 0.07 & 0.08 & 0.09 & 0.02 & 0.06 & 0.04 & 0.15 \\
\hline \multicolumn{9}{|l|}{ Professional training } \\
\hline None & 0.46 & 0.48 & 0.35 & 0.40 & 0.85 & 0.36 & 0.93 & 0.55 \\
\hline Apprenticeship/University & 0.54 & 0.52 & 0.65 & 0.60 & 0.15 & 0.64 & 0.07 & 0.45 \\
\hline \multicolumn{9}{|c|}{ During the last three years before unemployment entry, months spent in ... } \\
\hline regular employment & 18.94 & 16.77 & 19.73 & 18.95 & 8.92 & 20.10 & 5.71 & 14.81 \\
\hline ALMP & 2.72 & 2.15 & 2.74 & 2.34 & 3.10 & 2.31 & 3.14 & 1.77 \\
\hline unemployment & 4.35 & 3.71 & 4.28 & 4.61 & 4.98 & 4.35 & 3.20 & 3.24 \\
\hline inactivity & 9.50 & 12.89 & 8.70 & 9.67 & 17.78 & 9.08 & 21.46 & 14.68 \\
\hline \multicolumn{9}{|c|}{ Last activity before entry into unemployment } \\
\hline Regular employment & 0.70 & 0.65 & 0.74 & 0.69 & 0.59 & 0.74 & 0.48 & 0.63 \\
\hline Education, training, never employed & 0.21 & 0.27 & 0.18 & 0.23 & 0.24 & 0.19 & 0.38 & 0.26 \\
\hline Other & 0.09 & 0.08 & 0.07 & 0.08 & 0.17 & 0.07 & 0.15 & 0.11 \\
\hline Number of placement propositions & 4.22 & 3.85 & 4.27 & 4.56 & 3.02 & 3.58 & 1.47 & 2.32 \\
\hline
\end{tabular}

Note: Characteristics are measured at point of entry into unemployment. Numbers are shares unless indicated otherwise.

Abbreviation index: JS: job search assistance; STT: short-term training; JWS: JUMP wage subsidies; WS: SGB III wage subsidies; FT: further training (medium to long-term); PT: preparatory training; NP: non-participants. 
Table 3: Timing of (potential) entry into treatment, for participants and non-participants

\begin{tabular}{|c|c|c|c|c|c|c|c|c|}
\hline \multicolumn{9}{|c|}{ East Germany } \\
\hline Entry & JS & $\overline{\mathrm{STT}}$ & JWS & WS & JCS & FT & $\overline{\mathrm{PT}}$ & NP \\
\hline$\frac{1-3 \text { months } \mathrm{N}}{\%}$ & $\begin{array}{c}758 \\
56.36\end{array}$ & $\begin{array}{c}516 \\
52.71\end{array}$ & $\begin{array}{c}609 \\
61.45\end{array}$ & $\begin{array}{c}299 \\
68.11\end{array}$ & $\begin{array}{c}202 \\
29.71\end{array}$ & $\begin{array}{c}181 \\
44.25\end{array}$ & $\begin{array}{c}257 \\
50.39\end{array}$ & $\begin{array}{l}12,119 \\
100.00\end{array}$ \\
\hline $\begin{array}{l}4-6 \text { months } \mathrm{N} \\
\%\end{array}$ & $\begin{array}{c}256 \\
19.03\end{array}$ & $\begin{array}{c}228 \\
23.29\end{array}$ & $\begin{array}{c}195 \\
19.68\end{array}$ & $\begin{array}{c}75 \\
17.08\end{array}$ & $\begin{array}{c}156 \\
22.94\end{array}$ & $\begin{array}{c}136 \\
33.25\end{array}$ & $\begin{array}{c}127 \\
24.90\end{array}$ & $\begin{array}{l}9,304 \\
76.77\end{array}$ \\
\hline $\begin{array}{l}7-12 \text { months } \mathrm{N} \\
\%\end{array}$ & $\begin{array}{c}331 \\
24.61\end{array}$ & $\begin{array}{c}235 \\
24.00\end{array}$ & $\begin{array}{c}187 \\
18.87\end{array}$ & $\begin{array}{c}65 \\
14.81\end{array}$ & $\begin{array}{c}322 \\
47.35\end{array}$ & $\begin{array}{c}92 \\
22.49\end{array}$ & $\begin{array}{c}126 \\
24.71\end{array}$ & $\begin{array}{l}8,444 \\
69.68\end{array}$ \\
\hline Total & 1,345 & 979 & 991 & 439 & 680 & 409 & 510 & \\
\hline \multicolumn{9}{|c|}{ West Germany } \\
\hline$\frac{1-3 \text { months } \mathrm{N}}{\%}$ & $\begin{array}{l}1,059 \\
55.30\end{array}$ & $\begin{array}{l}1,049 \\
55.65\end{array}$ & $\begin{array}{c}311 \\
49.52\end{array}$ & $\begin{array}{c}322 \\
64.14\end{array}$ & $\begin{array}{c}283 \\
49.65\end{array}$ & $\begin{array}{c}289 \\
56.12\end{array}$ & $\begin{array}{c}588 \\
58.10\end{array}$ & $\begin{array}{c}26,410 \\
100\end{array}$ \\
\hline $\begin{array}{l}4-6 \text { months } \mathrm{N} \\
\%\end{array}$ & $\begin{array}{c}438 \\
22.87\end{array}$ & $\begin{array}{c}429 \\
22.76\end{array}$ & $\begin{array}{c}177 \\
28.18\end{array}$ & $\begin{array}{c}115 \\
22.91\end{array}$ & $\begin{array}{c}121 \\
21.23\end{array}$ & $\begin{array}{c}123 \\
23.88\end{array}$ & $\begin{array}{r}230 \\
22.73\end{array}$ & $\begin{array}{c}17,561 \\
66.49\end{array}$ \\
\hline $\begin{array}{l}7-12 \text { months } \mathrm{N} \\
\%\end{array}$ & $\begin{array}{r}418 \\
21.83\end{array}$ & $\begin{array}{c}407 \\
21.59\end{array}$ & $\begin{array}{c}140 \\
22.29\end{array}$ & $\begin{array}{c}65 \\
12.95\end{array}$ & $\begin{array}{c}166 \\
29.12\end{array}$ & $\begin{array}{c}103 \\
20.00\end{array}$ & $\begin{array}{r}194 \\
19.17\end{array}$ & $\begin{array}{c}14,874 \\
56.32\end{array}$ \\
\hline Total & 1,915 & 1,885 & 628 & 502 & 570 & 515 &, 012 & \\
\hline
\end{tabular}

Note: Calculations are based on the estimation sample. Non-participants are considered controls in the respective time window if they are observed unemployed at least until the first month of the time window.

Abbreviation index: JS: job search assistance; STT: short-term training; JWS: JUMP wage subsidies; WS: $S G B I I I$ wage subsidies; FT: further training (medium to long-term); PT: preparatory training; NP: non-participants. 
Table 4: Set of covariates included in the propensity score estimation

\begin{tabular}{|c|c|}
\hline Information category & Specification details \\
\hline $\begin{array}{l}\text { Socio-demographic } \\
\text { characteristics }\end{array}$ & $\begin{array}{l}\text { Gender (dummy: Female) } \\
\text { Age (dummy: below or above } 20 \text { years) } \\
\text { Living situation: } \\
\text { - living alone } \\
\text { - living together married } \\
\text { - living together not married } \\
\text { Migration status (dummy) } \\
\text { Having children (dummy) }\end{array}$ \\
\hline $\begin{array}{l}\text { Education level and } \\
\text { health condition }\end{array}$ & $\begin{array}{l}\text { School leaving certificate } \\
\text { - none } \\
\text { - lower secondary degree } \\
\text { - middle secondary degree } \\
\text { - upper/specialized secondary degree } \\
\text { Having finished professional/vocational training (dummy) } \\
\text { Health restrictions (dummy) }\end{array}$ \\
\hline $\begin{array}{l}\text { Information on last } \\
\text { activity/employment }\end{array}$ & $\begin{array}{l}\text { Last activity before entry into unemployment } \\
\text { - regular employment } \\
\text { - education, training, never employed } \\
\text { - other } \\
\text { Occupational group of previous job } \\
\text { - agriculture } \\
\text { - manufacturing, technical occupations } \\
\text { - services } \\
\text { - other } \\
\text { Having professional experience (dummy) } \\
\text { Daily income from last regular employment (log) } \\
\text { Information available on working time at last employer (dummy) }\end{array}$ \\
\hline $\begin{array}{l}\text { Labor market history } \\
\text { for past year and past } \\
\text { three years }\end{array}$ & $\begin{array}{l}\text { During the last year before unemployment entry (linear) } \\
\text { - months spent in employment } \\
\text { - months spent in unemployment } \\
\text { - months spent in ALMP } \\
\text { - months spent in inactivity } \\
\text { - months spent in full-time employment }{ }^{(1)} \\
\text { - months spent in part-time employment }{ }^{(1)} \\
\text { During the last three years up to unemployment entry (linear) } \\
\text { - months spent in employment } \\
\text { - months spent in unemployment } \\
\text { - months spent in ALMP } \\
\text { - months spent in inactivity } \\
\text { - months spent in full-time employment }{ }^{(1)} \\
\text { - months spent in part-time employment }{ }^{(1)} \\
\text { During the last three years up to unemployment entry (dummy) } \\
\text { - never been in regular employment } \\
\text { - never been in ALMP } \\
\text { - never been in inactivity } \\
\text { - never in full-time employment } \\
\text { - never in part-time employment }{ }^{(1)} \\
\end{array}$ \\
\hline $\begin{array}{l}\text { Information on current } \\
\text { unemployment and } \\
\text { caseworker } \\
\text { information }\end{array}$ & $\begin{array}{l}\text { Months of remaining benefit entitlement (linear) } \\
\text { Quarter of entry into unemployment ( } 4 \text { dummies) } \\
\text { Unemployment spell lasts until } 2003 \text { (dummy) } \\
\text { Months since last contact to employment agency } \\
\text { - never contacted before } \\
\text { - less than six months } \\
\text { - more than six months } \\
\text { - information missing } \\
\text { Information available on preferred working time (dummy) } \\
\text { Number of placement propositions by caseworker (linear and squared) }\end{array}$ \\
\hline $\begin{array}{l}\text { Regional } \\
\text { Characteristics }\end{array}$ & $\begin{array}{l}\text { Unemployment rate (linear) } \\
\text { GDP growth during last year (log) }\end{array}$ \\
\hline
\end{tabular}

Note: This baseline specification was modified if observations where dropped from the analysis due to lack of variation. In particular we dropped the variable "information of working time wanted" for the case of JCS, WS, PT and FT measures; information on previous employment occupation for PT and FT; the square of the placement proposition for WS and PT; and the information on migration status for FT.

(1) The information of working time available can be divided into three categories, full-time, part-time and "not quite full-time". The latter was dropped from the analysis. 
Table 5: Cumulative treatment effects 30 and 60 months after program entry on regular employment probabilities

\begin{tabular}{|c|c|c|c|c|c|c|c|c|c|}
\hline & & \multicolumn{5}{|c|}{ East Germany } & \multicolumn{3}{|c|}{ West Germany } \\
\hline & $\begin{array}{c}\text { Entry time/ } \\
\sum\end{array}$ & All & $1-3$ & $4-6$ & $7-12$ & All & $1-3$ & $4-6$ & $7-12$ \\
\hline \multirow[t]{2}{*}{ JS } & $\begin{array}{l}\sum 30 \\
\text { (s.e.) }\end{array}$ & $\begin{array}{l}\mathbf{1 . 4 9} \\
(0.25)\end{array}$ & $\begin{array}{c}\mathbf{0 . 9 4} \\
(0.35)\end{array}$ & $\begin{array}{l}\mathbf{2 . 2 8} \\
(0.56)\end{array}$ & $\begin{array}{l}\mathbf{2 . 1 5} \\
(0.54)\end{array}$ & $\begin{array}{l}\mathbf{1 . 3 7} \\
(0.22)\end{array}$ & $\begin{array}{c}0.48 \\
(0.28)\end{array}$ & $\begin{array}{l}\mathbf{2 . 0 9} \\
(0.43)\end{array}$ & $\begin{array}{l}\mathbf{2 . 8 6} \\
(0.51)\end{array}$ \\
\hline & $\begin{array}{l}\sum 60 \\
\text { (s.e.) }\end{array}$ & $\begin{array}{c}\mathbf{3 . 8 1} \\
(0.54)\end{array}$ & $\begin{array}{l}\mathbf{3 . 3 3} \\
(0.72)\end{array}$ & $\begin{array}{c}\mathbf{5 . 3 5} \\
(1.18)\end{array}$ & $\begin{array}{c}\mathbf{3 . 7 4} \\
(1.13)\end{array}$ & $\begin{array}{l}\mathbf{2 . 8 5} \\
(0.42)\end{array}$ & $\begin{array}{l}\mathbf{1 . 4 1} \\
(0.56)\end{array}$ & $\begin{array}{c}\mathbf{3 . 5 4} \\
(0.83)\end{array}$ & $\begin{array}{l}\mathbf{5 . 7 6} \\
(0.99)\end{array}$ \\
\hline \multirow[t]{2}{*}{ STT } & $\begin{array}{l}\sum 30 \\
\text { (s.e.) }\end{array}$ & $\begin{array}{l}\mathbf{1 . 2 7} \\
(0.31)\end{array}$ & $\begin{array}{c}0.61 \\
(0.43)\end{array}$ & $\begin{array}{l}\mathbf{1 . 7 5} \\
(0.58)\end{array}$ & $\begin{array}{c}\mathbf{2 . 2 8} \\
(0.70)\end{array}$ & $\begin{array}{c}\mathbf{0 . 9 8} \\
(0.23)\end{array}$ & $\begin{array}{c}0.02 \\
(0.32)\end{array}$ & $\begin{array}{l}\mathbf{2 . 1 8} \\
(0.48)\end{array}$ & $\begin{array}{l}\mathbf{2 . 1 7} \\
(0.48)\end{array}$ \\
\hline & $\begin{array}{l}\sum 60 \\
\text { (s.e.) }\end{array}$ & $\begin{array}{c}\mathbf{3 . 6 5} \\
(0.57)\end{array}$ & $\begin{array}{l}\mathbf{2 . 8 2} \\
(0.82)\end{array}$ & $\begin{array}{c}\mathbf{4 . 8 6} \\
(1.16)\end{array}$ & $\begin{array}{l}\mathbf{4 . 2 8} \\
(1.34)\end{array}$ & $\begin{array}{l}\mathbf{2 . 7 5} \\
(0.45)\end{array}$ & $\begin{array}{l}\mathbf{1 . 8 6} \\
(0.61)\end{array}$ & $\begin{array}{l}\mathbf{4 . 6 9} \\
(0.88)\end{array}$ & $\begin{array}{c}\mathbf{3 . 0 0} \\
(1.03)\end{array}$ \\
\hline \multirow[t]{2}{*}{ JWS } & $\begin{array}{l}\sum 30 \\
\text { (s.e.) }\end{array}$ & $\begin{array}{c}\mathbf{3 . 1 0} \\
(0.31)\end{array}$ & $\begin{array}{l}\mathbf{1 . 6 0} \\
(0.38)\end{array}$ & $\begin{array}{c}\mathbf{5 . 4 7} \\
(0.62)\end{array}$ & $\begin{array}{c}\mathbf{5 . 5 1} \\
(0.73)\end{array}$ & $\begin{array}{l}\mathbf{4 . 1 6} \\
(0.38)\end{array}$ & $\begin{array}{c}\mathbf{2 . 3 4} \\
(0.50)\end{array}$ & $\begin{array}{l}\mathbf{4 . 8 6} \\
(0.57)\end{array}$ & $\begin{array}{c}\mathbf{7 . 2 8} \\
(0.80)\end{array}$ \\
\hline & $\begin{array}{l}\sum 60 \\
\text { (s.e.) }\end{array}$ & $\begin{array}{l}\mathbf{9 . 0 9} \\
(0.62)\end{array}$ & $\begin{array}{l}\mathbf{7 . 3 7} \\
(0.78)\end{array}$ & $\begin{array}{c}\mathbf{1 2 . 3 6} \\
(1.39)\end{array}$ & $\begin{array}{l}\mathbf{1 1 . 2 7} \\
(1.55)\end{array}$ & $\begin{array}{l}\mathbf{8 . 5 3} \\
(0.71)\end{array}$ & $\begin{array}{c}\mathbf{6 . 1 6} \\
(0.99)\end{array}$ & $\begin{array}{c}\mathbf{9 . 2 0} \\
(1.23)\end{array}$ & $\begin{array}{l}\mathbf{1 2 . 9 2} \\
(1.63)\end{array}$ \\
\hline \multirow[t]{2}{*}{ WS } & $\begin{array}{l}\sum 30 \\
\text { (s.e.) }\end{array}$ & $\begin{array}{l}\mathbf{3 . 5 3} \\
(0.49)\end{array}$ & $\begin{array}{l}\mathbf{2 . 9 4} \\
(0.56)\end{array}$ & $\begin{array}{l}\mathbf{5 . 5 5} \\
(1.08)\end{array}$ & $\begin{array}{l}\mathbf{3 . 8 9} \\
(1.17)\end{array}$ & $\begin{array}{l}\mathbf{2 . 4 2} \\
(0.47)\end{array}$ & $\begin{array}{l}\mathbf{1 . 8 0} \\
(0.53)\end{array}$ & $\begin{array}{l}\mathbf{3 . 2 2} \\
(0.87)\end{array}$ & $\begin{array}{c}\mathbf{4 . 1 1} \\
(1.46)\end{array}$ \\
\hline & $\begin{array}{l}\sum 60 \\
\text { (s.e.) }\end{array}$ & $\begin{array}{l}\mathbf{8 . 4 9} \\
(1.02)\end{array}$ & $\begin{array}{c}\mathbf{8 . 1 2} \\
(1.14)\end{array}$ & $\begin{array}{l}\mathbf{1 0 . 4 0} \\
(2.36)\end{array}$ & $\begin{array}{l}\mathbf{7 . 9 6} \\
(2.57)\end{array}$ & $\begin{array}{l}\mathbf{4 . 9 2} \\
(0.86)\end{array}$ & $\begin{array}{l}\mathbf{3 . 6 0} \\
(1.00)\end{array}$ & $\begin{array}{c}\mathbf{6 . 7 0} \\
(1.62)\end{array}$ & $\begin{array}{l}\mathbf{8 . 3 2} \\
(2.60)\end{array}$ \\
\hline \multirow[t]{2}{*}{ JCS } & $\begin{array}{l}\sum 30 \\
\text { (s.e.) }\end{array}$ & $\begin{array}{l}\mathbf{- 1 . 4 7} \\
(0.25)\end{array}$ & $\begin{array}{l}\mathbf{- 2 . 8 6} \\
(0.46)\end{array}$ & $\begin{array}{l}\mathbf{- 1 . 0 1} \\
(0.49)\end{array}$ & $\begin{array}{l}-0.81 \\
(0.42)\end{array}$ & $\begin{array}{l}\mathbf{- 1 . 3 8} \\
(0.30)\end{array}$ & $\begin{array}{l}\mathbf{- 2 . 4 7} \\
(0.40)\end{array}$ & $\begin{array}{l}-0.02 \\
(0.70)\end{array}$ & $\begin{array}{c}-0.52 \\
(0.58)\end{array}$ \\
\hline & $\begin{array}{l}\sum 60 \\
\text { (s.e.) }\end{array}$ & $\begin{array}{r}\mathbf{- 2 . 3 8} \\
(0.56)\end{array}$ & $\begin{array}{r}\mathbf{- 3 . 7 6} \\
(1.01)\end{array}$ & $\begin{array}{l}-1.12 \\
(1.07)\end{array}$ & $\begin{array}{r}\mathbf{- 2 . 1 3} \\
(0.84)\end{array}$ & $\begin{array}{r}\mathbf{- 1 . 6 3} \\
(0.64)\end{array}$ & $\begin{array}{r}\mathbf{- 2 . 5 9 9} \\
(0.95)\end{array}$ & $\begin{array}{l}-0.47 \\
(1.50)\end{array}$ & $\begin{array}{l}-0.84 \\
(1.21)\end{array}$ \\
\hline \multirow[t]{2}{*}{$\mathrm{FT}$} & $\begin{array}{l}\sum 30 \\
\text { (s.e.) }\end{array}$ & $\begin{array}{c}0.27 \\
(0.44)\end{array}$ & $\begin{array}{r}\mathbf{- 1 . 7 9} \\
(0.61)\end{array}$ & $\begin{array}{c}\mathbf{1 . 8 1} \\
(0.71)\end{array}$ & $\begin{array}{c}\mathbf{2 . 0 9} \\
(1.01)\end{array}$ & $\begin{array}{c}\mathbf{1 . 2 3} \\
(0.44)\end{array}$ & $\begin{array}{c}0.48 \\
(0.58)\end{array}$ & $\begin{array}{c}\mathbf{2 . 3 5} \\
(0.85)\end{array}$ & $\begin{array}{c}\mathbf{2 . 0 0} \\
(0.90)\end{array}$ \\
\hline & $\begin{array}{l}\sum 60 \\
((\text { s.e. })\end{array}$ & $\begin{array}{c}\mathbf{2 . 8 6} \\
(0.98)\end{array}$ & $\begin{array}{l}-0.07 \\
(1.35)\end{array}$ & $\begin{array}{c}\mathbf{5 . 1 5} \\
(1.53)\end{array}$ & $\begin{array}{l}\mathbf{5 . 2 8} \\
(2.17)\end{array}$ & $\begin{array}{c}\mathbf{4 . 4 7} \\
(0.83)\end{array}$ & $\begin{array}{c}\mathbf{3 . 6 1} \\
(1.09)\end{array}$ & $\begin{array}{c}\mathbf{6 . 0 3} \\
(1.69)\end{array}$ & $\begin{array}{c}\mathbf{5 . 0 4} \\
(2.01)\end{array}$ \\
\hline \multirow[t]{2}{*}{$\mathrm{PT}$} & $\begin{array}{l}\sum 30 \\
\text { (s.e.) }\end{array}$ & $\begin{array}{c}\mathbf{- 1 . 6 4} \\
(0.20)\end{array}$ & $\begin{array}{c}\mathbf{- 2 . 0 9} \\
(0.29)\end{array}$ & $\begin{array}{r}\mathbf{- 0 . 8 7} \\
(0.31)\end{array}$ & $\begin{array}{r}\mathbf{- 1 . 5 0} \\
(0.44)\end{array}$ & $\begin{array}{c}\mathbf{- 2 . 1 4} \\
(0.20)\end{array}$ & $\begin{array}{c}\mathbf{- 2 . 6 5} \\
(0.24)\end{array}$ & $\begin{array}{c}\mathbf{- 0 . 9 9} \\
(0.38)\end{array}$ & $\begin{array}{c}\mathbf{- 1 . 9 6} \\
(0.49)\end{array}$ \\
\hline & $\begin{array}{c}\sum 60 \\
\text { (s.e.) }\end{array}$ & $\begin{array}{c}\mathbf{- 3 . 4 3} \\
(0.43)\end{array}$ & $\begin{array}{c}-\mathbf{4 . 1 3} \\
(0.59)\end{array}$ & $\begin{array}{c}\mathbf{- 2 . 4 5} \\
(0.70)\end{array}$ & $\begin{array}{r}\mathbf{- 3 . 0 1} \\
(0.93)\end{array}$ & $\begin{array}{c}\mathbf{- 3 . 0 9} \\
(0.42)\end{array}$ & $\begin{array}{c}\mathbf{- 3 . 9 8} \\
(0.51)\end{array}$ & $\begin{array}{r}\mathbf{- 1 . 1 5} \\
(0.86)\end{array}$ & $\begin{array}{c}\mathbf{- 2 . 6 9} \\
(0.95)\end{array}$ \\
\hline
\end{tabular}

Note: Cumulative effects are obtained by summing up the monthly treatment effects. Standard errors in parentheses are obtained by bootstrapping with 200 replications. Bold numbers indicate significance at the $5 \%$ level.

Abbreviation index: JS: job search assistance; STT: short-term training; JWS: JUMP wage subsidies; WS: $S G B I I I$ wage subsidies; FT: further training (medium to long-term); PT: preparatory training; NP: non-participants. 
Table 6: Cumulative treatment effect 30 and 60 months after program entry on education participation

\begin{tabular}{|c|c|c|c|c|c|c|c|c|c|}
\hline & & \multicolumn{4}{|c|}{ East Germany } & \multicolumn{4}{|c|}{ West Germany } \\
\hline & $\begin{array}{c}\text { Entry time/ } \\
\sum\end{array}$ & All & $1-3$ & $4-6$ & $7-12$ & All & $1-3$ & $4-6$ & $7-12$ \\
\hline \multirow[t]{2}{*}{ JS } & $\begin{array}{l}\sum 30 \\
\text { (s.e.) }\end{array}$ & $\begin{array}{l}\mathbf{- 1 . 1 4} \\
(0.14)\end{array}$ & $\begin{array}{l}\mathbf{- 1 . 0 2} \\
(0.16)\end{array}$ & $\begin{array}{l}-0.62 \\
(0.39)\end{array}$ & $\begin{array}{l}\mathbf{- 1 . 8 2} \\
(0.31)\end{array}$ & $\begin{array}{l}\mathbf{- 0 . 9 9} \\
(0.14)\end{array}$ & $\begin{array}{c}\mathbf{- 0 . 5 5} \\
(0.19)\end{array}$ & $\begin{array}{r}\mathbf{- 1 . 1 6} \\
(0.27)\end{array}$ & $\begin{array}{l}\mathbf{- 1 . 9 3} \\
(0.28)\end{array}$ \\
\hline & $\begin{array}{l}\sum 60 \\
\text { (s.e.) }\end{array}$ & $\begin{array}{r}\mathbf{- 1 . 6 4} \\
(0.26)\end{array}$ & $\begin{array}{r}\mathbf{- 1 . 5 4} \\
(0.31)\end{array}$ & $\begin{array}{l}-0.84 \\
(0.68)\end{array}$ & $\begin{array}{r}\mathbf{- 2 . 4 9} \\
(0.62)\end{array}$ & $\begin{array}{l}\mathbf{- 1 . 4} \\
(0.25)\end{array}$ & $\begin{array}{r}\mathbf{- 0 . 7 1} \\
(0.34)\end{array}$ & $\begin{array}{r}\mathbf{- 1 . 6 1} \\
(0.48)\end{array}$ & $\begin{array}{l}\mathbf{- 2 . 9 3} \\
(0.45)\end{array}$ \\
\hline \multirow[t]{2}{*}{ STT } & $\begin{array}{l}\sum 30 \\
\text { (s.e.) }\end{array}$ & $\begin{array}{r}-\mathbf{- 1 . 2 6} \\
(0.19)\end{array}$ & $\begin{array}{l}\mathbf{- 0 . 7 6} \\
(0.28)\end{array}$ & $\begin{array}{r}\mathbf{- 2 . 1 0} \\
(0.30)\end{array}$ & $\begin{array}{l}\mathbf{- 1 . 5 6} \\
(0.40)\end{array}$ & $\begin{array}{r}\mathbf{- 1 . 0 0} \\
(0.15)\end{array}$ & $\begin{array}{r}\mathbf{- 0 . 7 3} \\
(0.21)\end{array}$ & $\begin{array}{l}\mathbf{- 1 . 1 5} \\
(0.30)\end{array}$ & $\begin{array}{l}\mathbf{- 1 . 5 5} \\
(0.33)\end{array}$ \\
\hline & $\begin{array}{l}\sum 60 \\
\text { (s.e.) }\end{array}$ & $\begin{array}{l}\mathbf{- 1 . 5 4} \\
(0.34)\end{array}$ & $\begin{array}{r}\mathbf{- 1 . 0 6} \\
(0.47)\end{array}$ & $\begin{array}{l}\mathbf{- 2 . 6 4} \\
(0.58)\end{array}$ & $\begin{array}{l}\mathbf{- 1 . 5 4} \\
(0.73)\end{array}$ & $\begin{array}{r}\mathbf{- 1 . 3 1} \\
(0.25)\end{array}$ & $\begin{array}{r}\mathbf{- 1 . 0 4} \\
(0.36)\end{array}$ & $\begin{array}{l}\mathbf{- 1 . 6 5} \\
(0.50)\end{array}$ & $\begin{array}{r}\mathbf{- 1 . 6 5} \\
(0.59)\end{array}$ \\
\hline \multirow[t]{2}{*}{ JWS } & $\begin{array}{l}\sum 30 \\
\text { (s.e.) }\end{array}$ & $\begin{array}{l}\mathbf{- 2 . 4 9} \\
(0.15)\end{array}$ & $\begin{array}{l}\mathbf{- 2 . 2 3} \\
(0.18)\end{array}$ & $\begin{array}{l}\mathbf{- 2 . 7 7} \\
(0.28)\end{array}$ & $\begin{array}{l}\mathbf{- 3 . 0 7} \\
(0.37)\end{array}$ & $\begin{array}{l}\mathbf{- 2 . 2 0} \\
(0.16)\end{array}$ & $\begin{array}{l}\mathbf{- 1 . 7 0} \\
(0.25)\end{array}$ & $\begin{array}{l}\mathbf{- 2 . 4 3} \\
(0.27)\end{array}$ & $\begin{array}{l}\mathbf{- 3 . 0 1} \\
(0.34)\end{array}$ \\
\hline & $\begin{array}{l}\sum 60 \\
\text { (s.e.) }\end{array}$ & $\begin{array}{l}\mathbf{- 3 . 9 1} \\
(0.27)\end{array}$ & $\begin{array}{l}\mathbf{- 3 . 4 8} \\
(0.35)\end{array}$ & $\begin{array}{l}-4.14 \\
(0.64)\end{array}$ & $\begin{array}{l}\mathbf{- 5 . 0 8} \\
(0.54)\end{array}$ & $\begin{array}{l}\mathbf{- 3 . 1 6} \\
(0.32)\end{array}$ & $\begin{array}{r}\mathbf{- 2 . 1 4} \\
(0.52)\end{array}$ & $\begin{array}{l}-4.15 \\
(0.48)\end{array}$ & $\begin{array}{l}-4.17 \\
(0.77)\end{array}$ \\
\hline \multirow[t]{2}{*}{$\mathrm{WS}$} & $\begin{array}{l}\sum 30 \\
\text { (s.e.) }\end{array}$ & $\begin{array}{l}\mathbf{- 2 . 3 2} \\
(0.23)\end{array}$ & $\begin{array}{l}\mathbf{- 2 . 2 3} \\
(0.26)\end{array}$ & $\begin{array}{l}\mathbf{- 3 . 1 8} \\
(0.47)\end{array}$ & $\begin{array}{l}\mathbf{- 1 . 7 3} \\
(0.71)\end{array}$ & $\begin{array}{l}\mathbf{- 1 . 3 4} \\
(0.22)\end{array}$ & $\begin{array}{l}\mathbf{- 1 . 0 5} \\
(0.29)\end{array}$ & $\begin{array}{l}\mathbf{- 2 . 0 1} \\
(0.40)\end{array}$ & $\begin{array}{l}\mathbf{- 1 . 5 5} \\
(0.58)\end{array}$ \\
\hline & $\begin{array}{l}\sum 60 \\
\text { (s.e.) }\end{array}$ & $\begin{array}{l}\mathbf{- 3 . 7 3} \\
(0.40)\end{array}$ & $\begin{array}{l}\mathbf{- 3 . 9 8} \\
(0.45)\end{array}$ & $\begin{array}{l}-4.01 \\
(0.94)\end{array}$ & $\begin{array}{l}-2.28 \\
(1.18)\end{array}$ & $\begin{array}{r}\mathbf{- 2 . 2 0} \\
(0.40)\end{array}$ & $\begin{array}{r}\mathbf{- 1 . 8 4} \\
(0.52)\end{array}$ & $\begin{array}{l}\mathbf{- 2 . 9 8} \\
(0.81)\end{array}$ & $\begin{array}{l}\mathbf{- 2 . 5 7} \\
(0.89)\end{array}$ \\
\hline \multirow[t]{2}{*}{ JCS } & $\begin{array}{l}\sum 30 \\
\text { (s.e.) }\end{array}$ & $\begin{array}{l}\mathbf{- 1 . 5 8} \\
(0.22)\end{array}$ & $\begin{array}{l}\mathbf{- 1 . 3 0} \\
(0.37)\end{array}$ & $\begin{array}{l}\mathbf{- 1 . 3 2} \\
(0.38)\end{array}$ & $\begin{array}{l}\mathbf{- 1 . 8 8} \\
(0.36)\end{array}$ & $\begin{array}{r}\mathbf{- 0 . 9 6} \\
(0.28)\end{array}$ & $\begin{array}{l}-0.21 \\
(0.42)\end{array}$ & $\begin{array}{l}\mathbf{- 1 . 6 4} \\
(0.52)\end{array}$ & $\begin{array}{l}\mathbf{- 1 . 7 5} \\
(0.43)\end{array}$ \\
\hline & $\begin{array}{l}\sum 60 \\
\text { (s.e.) }\end{array}$ & $\begin{array}{r}\mathbf{- 1 . 8 2} \\
(0.43)\end{array}$ & $\begin{array}{l}-1.26 \\
(0.71)\end{array}$ & $\begin{array}{r}\mathbf{- 1 . 7 7} \\
(0.79)\end{array}$ & $\begin{array}{c}\mathbf{- 2 . 2} \\
(0.66)\end{array}$ & $\begin{array}{l}-0.73 \\
(0.54)\end{array}$ & $\begin{array}{c}0.25 \\
(0.80)\end{array}$ & $\begin{array}{l}-1.19 \\
(1.13)\end{array}$ & $\begin{array}{r}\mathbf{- 2 . 0 6} \\
(0.80)\end{array}$ \\
\hline \multirow[t]{2}{*}{ FT } & $\begin{array}{l}\sum 30 \\
\text { (s.e.) }\end{array}$ & $\begin{array}{c}\mathbf{- 1 . 8 5} \\
(0.21)\end{array}$ & $\begin{array}{c}\mathbf{- 1 . 6 0} \\
(0.34)\end{array}$ & $\begin{array}{c}\mathbf{- 2 . 1 2} \\
(0.33)\end{array}$ & $\begin{array}{c}\mathbf{- 1 . 9 6} \\
(0.58)\end{array}$ & $\begin{array}{r}\mathbf{- 1 . 7 9} \\
(0.21)\end{array}$ & $\begin{array}{r}\mathbf{- 1 . 6 7} \\
(0.27)\end{array}$ & $\begin{array}{c}\mathbf{- 1 . 9 4} \\
(0.40)\end{array}$ & $\begin{array}{c}\mathbf{- 1 . 9 5} \\
(0.58)\end{array}$ \\
\hline & $\begin{array}{l}\sum 60 \\
\text { (s.e.) }\end{array}$ & $\begin{array}{l}\mathbf{- 2 . 9 1} \\
(0.43)\end{array}$ & $\begin{array}{r}\mathbf{- 2 . 8 7} \\
(0.65)\end{array}$ & $\begin{array}{r}\mathbf{- 2 . 7 3} \\
(0.69)\end{array}$ & $\begin{array}{r}\mathbf{- 3 . 2 5} \\
(0.98)\end{array}$ & $\begin{array}{r}\mathbf{- 2 . 4 0} \\
(0.43)\end{array}$ & $\begin{array}{r}\mathbf{- 2 . 1 9} \\
(0.51)\end{array}$ & $\begin{array}{r}\mathbf{- 3 . 0 0} \\
(0.75)\end{array}$ & $\begin{array}{c}\mathbf{- 2 . 2 6} \\
(1.07)\end{array}$ \\
\hline \multirow[t]{2}{*}{$\mathrm{PT}$} & $\begin{array}{l}\sum 30 \\
\text { (s.e.) }\end{array}$ & $\begin{array}{c}0.65 \\
(0.42)\end{array}$ & $\begin{array}{c}0.82 \\
(0.63)\end{array}$ & $\begin{array}{l}-0.26 \\
(0.83)\end{array}$ & $\begin{array}{c}1.22 \\
(0.87)\end{array}$ & $\begin{array}{c}\mathbf{1 . 4 7} \\
(0.27)\end{array}$ & $\begin{array}{c}\mathbf{2 . 1 7} \\
(0.38)\end{array}$ & $\begin{array}{c}1.09 \\
(0.57)\end{array}$ & $\begin{array}{l}-0.23 \\
(0.56)\end{array}$ \\
\hline & $\underset{(\text { s.e) }}{\sum 60}$ & $\begin{array}{c}\mathbf{2 . 6 7} \\
(0.71)\end{array}$ & $\begin{array}{c}\mathbf{3 . 0 1} \\
(1.06)\end{array}$ & $\begin{array}{c}0.81 \\
(1.32)\end{array}$ & $\begin{array}{c}\mathbf{3 . 8 8} \\
(1.40)\end{array}$ & $\begin{array}{c}\mathbf{3 . 1 4} \\
(0.47)\end{array}$ & $\begin{array}{c}\mathbf{4 . 4 0} \\
(0.65)\end{array}$ & $\begin{array}{c}\mathbf{2 . 4 2} \\
(0.96)\end{array}$ & $\begin{array}{c}0.17 \\
(0.99)\end{array}$ \\
\hline
\end{tabular}

Note: Cumulative effects are obtained by summing up the monthly treatment effects. Standard errors in parentheses are obtained by bootstrapping with 200 replications. Bold numbers indicate significance at the $5 \%$ level.

Abbreviation index: JS: job search assistance; STT: short-term training; JWS: JUMP wage subsidies; WS: $S G B I I I$ wage subsidies; FT: further training (medium to long-term); PT: preparatory training; NP: non-participants. 
Table 7: Comparison of participant and non-participant highest vocational degree at point of entry into unemployment and 72 months later.

\begin{tabular}{|c|c|c|c|c|c|c|c|}
\hline & & \multicolumn{3}{|c|}{ East Germany } & \multicolumn{3}{|c|}{ West Germany } \\
\hline & & $t=0$ & $t=72$ & $\Delta$ & $t=0$ & $t=72$ & p-value \\
\hline \multirow{3}{*}{ JS } & Professional training & 023 & 018 & -005 & 0.46 & 030 & -007 \\
\hline & apprenticeship & $\begin{array}{l}0.23 \\
0.76\end{array}$ & $\begin{array}{l}0.10 \\
0.80\end{array}$ & $\begin{array}{r}-0.00 \\
0.04\end{array}$ & $\begin{array}{l}0.46 \\
0.53\end{array}$ & 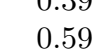 & $\begin{array}{r}-0.08 \\
0.06\end{array}$ \\
\hline & university & 0.00 & 0.02 & 0.02 & 0.01 & 0.02 & 0.01 \\
\hline \multirow{4}{*}{ STT } & Professional training & & & & & & \\
\hline & none & 0.29 & 0.24 & -0.05 & 0.48 & 0.41 & -0.07 \\
\hline & apprenticeship & 0.70 & 0.73 & 0.03 & 0.50 & 0.56 & 0.06 \\
\hline & university & 0.02 & 0.03 & 0.01 & 0.02 & 0.03 & 0.01 \\
\hline \multirow{4}{*}{ JWS } & Professional training & & & & & & \\
\hline & none & 0.13 & 0.10 & -0.03 & 0.35 & 0.32 & -0.03 \\
\hline & apprenticeship & 0.85 & 0.88 & 0.03 & 0.64 & 0.67 & 0.03 \\
\hline & university & 0.01 & 0.02 & 0.01 & 0.01 & 0.02 & 0.01 \\
\hline \multirow{4}{*}{ WS } & Professional training & & & & & & \\
\hline & none & 0.22 & 0.18 & -0.04 & 0.40 & 0.34 & -0.06 \\
\hline & apprenticeship & 0.76 & 0.79 & 0.03 & 0.59 & 0.63 & 0.04 \\
\hline & university & 0.02 & 0.03 & 0.01 & 0.01 & 0.03 & 0.02 \\
\hline \multirow{4}{*}{ JCS } & Professional training & & & & & & \\
\hline & none & 0.47 & 0.39 & -0.08 & 0.85 & 0.74 & -0.11 \\
\hline & apprenticeship & 0.52 & 0.58 & 0.06 & 0.14 & 0.22 & 0.08 \\
\hline & university & 0.01 & 0.03 & 0.02 & 0.01 & 0.04 & 0.03 \\
\hline \multirow{4}{*}{$\mathrm{FT}$} & Professional training & & & & & & \\
\hline & none & 0.17 & 0.13 & -0.04 & 0.36 & 0.32 & -0.04 \\
\hline & apprenticeship & 0.83 & 0.86 & 0.03 & 0.62 & 0.65 & 0.03 \\
\hline & university & 0.01 & 0.01 & 0.00 & 0.02 & 0.03 & 0.01 \\
\hline \multirow{4}{*}{$\mathrm{PT}$} & Professional training & & & & & & \\
\hline & none & 0.89 & 0.68 & -0.21 & 0.93 & 0.74 & -0.19 \\
\hline & apprenticeship & 0.09 & 0.29 & 0.20 & 0.06 & 0.23 & 0.17 \\
\hline & university & 0.02 & 0.03 & 0.01 & 0.01 & 0.03 & 0.02 \\
\hline \multirow{4}{*}{ NP } & Professional training & & & & & & \\
\hline & none & 0.52 & 0.41 & -0.11 & 0.55 & 0.48 & -0.07 \\
\hline & apprenticeship & 0.46 & 0.54 & 0.08 & 0.43 & 0.49 & 0.06 \\
\hline & university & 0.02 & 0.04 & 0.02 & 0.02 & 0.03 & 0.01 \\
\hline
\end{tabular}

Note: $\Delta$ depicts raw differences between the two values; bold numbers indicate significance at the $5 \%$-level from a one-sided t-test.

Abbreviation index: JS: job search assistance; STT: short-term training; JWS: JUMP wage subsidies; WS: $S G B I I I$ wage subsidies; FT: further training (medium to long-term); PT: preparatory training; NP: non-participants. 


\section{A Technical Appendix}

\section{A.1 Sample Selection}

Table A.1: Documentation of sample reduction

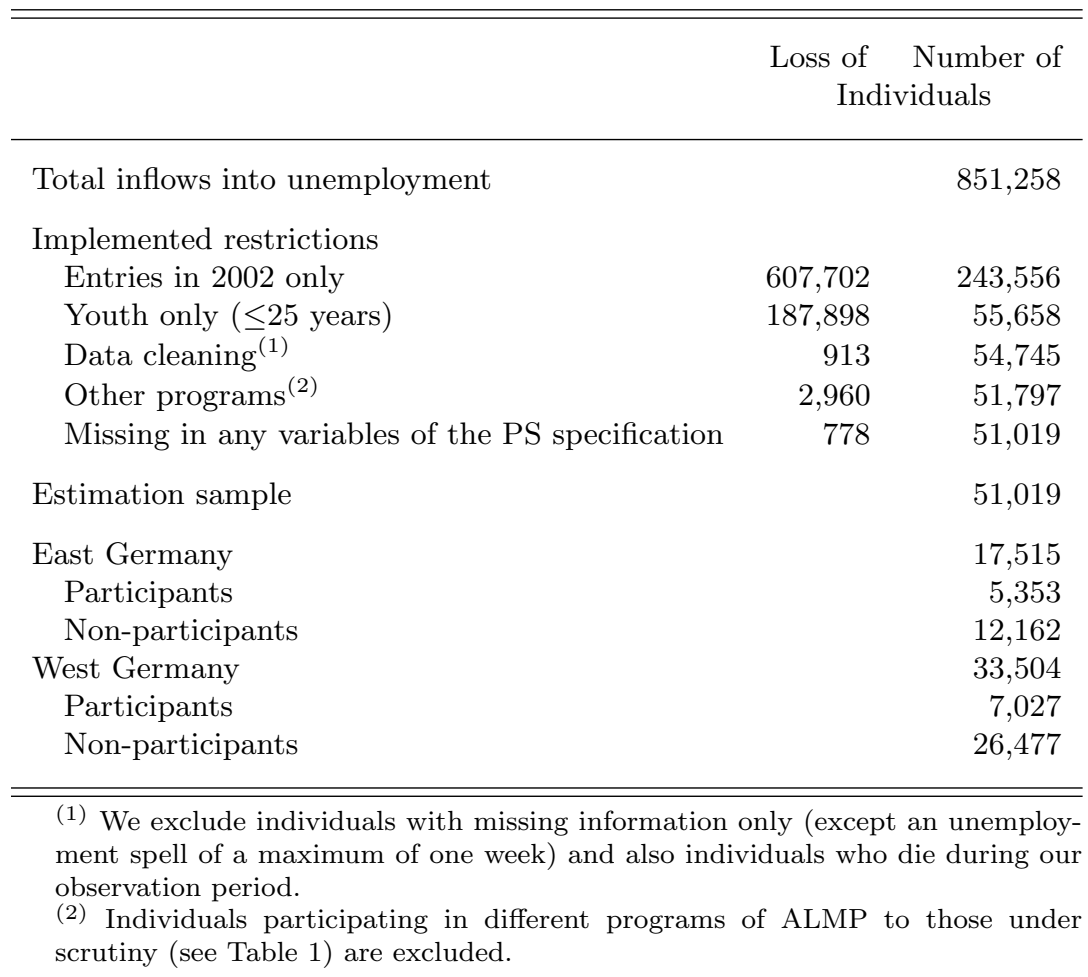




\section{A.2 Imputation of missing information}

To overcome the potential problem of non-randomly missing outcome information, we impute missing spells with information that is recorded with every registered spell of unemployment, employment or benefit receipt. In particular, for each of these spells the main planned activity subsequent to the spell is available; for each registered spell of unemployment, additional information on the previous activity is recorded by the caseworker.

For example, if an individual's status of being registered as unemployed changes because he has to serve in the army (which was compulsory for men within our observation period), he disappears from the registered data. Military service is recorded as the reason for leaving the unemployment status and we fill the missing period with this information. If this individual once again registers as unemployed after having served in the army, this can be verified, as we again should observe the military service as the previous activity. However, we only observe the previous activity if the individual registers as unemployed. If he or she finds employment, we have to rely on the initial leaving information of the unemployment spell before military service. Table A.2 summarizes the missing information that could be filled using this method.

Table A.2: Documentation of filling procedure

\begin{tabular}{|c|c|c|c|c|}
\hline & \multicolumn{2}{|c|}{ Individuals } & \multicolumn{2}{|c|}{ Months } \\
\hline & $\mathrm{N}$ & $\%$ & $\mathrm{~N}$ & $\%$ \\
\hline Total & 51,019 & 100 & $3,673,368$ & 100 \\
\hline Affected by missings & 36,493 & 71.53 & 942,564 & 25.66 \\
\hline Filled & & & 866,707 & 23.59 \\
\hline participants & & & 113,278 & 13.07 \\
\hline non-participants & & & 753,429 & 86.93 \\
\hline Remaining missings & 6,576 & 12.88 & 75,857 & 2.07 \\
\hline \multicolumn{5}{|l|}{ Filling details } \\
\hline \multicolumn{5}{|l|}{ Participants } \\
\hline$\%$ positive employment & & & 21,430 & 19.30 \\
\hline$\%$ positive education & & & 20,179 & 17.81 \\
\hline \multicolumn{5}{|l|}{ Non-participants } \\
\hline$\%$ positive employment & & & 145,454 & 18.92 \\
\hline$\%$ positive education & & & 161,270 & 21.40 \\
\hline
\end{tabular}

From the distribution of missing information across program participants and non-participants we see that the administrative records contain significantly more missings for nonparticipants. This can be explained by a lower attachment of these individuals to the FEA and hence a lower contact frequency to the caseworker. However, we also find that the type of imputed information is similarly distributed across the two groups for both outcomes considered, so that non-randomly distributed missings should not pose a problem for our analysis. 


\section{A.3 Details on Perfect Alignment}

The participants and non-participants are matched directly conditional on the calendar month of entry into unemployment and elapsed unemployment duration. As a starting point we estimate the average treatment effect on the treated for each cell, i.e., participants who entered unemployment in the $c^{t h}$ month of the year and have a program start after $p$ months in unemployment are compared to non-participants who are also entered unemployment in the $c^{t h}$ month and are still unemployed after $p$ months. Hence, within each cell defined by calendar month of unemployment entry and months elapsed before program entry, the effects are defined as:

$$
\begin{aligned}
& \tau_{c p}^{I P W}=E\left(Y^{1} \mid D=1, P(W), \text { UE-Entry }=c, \text { Prg-Entry }=\mathrm{p}\right)- \\
& E\left(Y^{0} \mid D=1, P(W) \text {, UE-Entry }=c, \text { UE-Duration } \geq p\right)
\end{aligned}
$$

In a second step the single cell-effects are aggregated to obtain the aggregate effect $\tau^{I P W}$. For this the 144 monthly effects $\tau_{c p}^{I P W}$ are weighted by the distribution of participants across cells:

$$
\tau^{I P W}=\sum_{c=1}^{12}\left(\sum_{p=1}^{12} \tau_{c p}^{I P W} \cdot \frac{N_{c p}^{1}}{N_{c}^{1}}\right) \cdot \frac{N_{c}^{1}}{N^{1}},
$$

with $N_{c p}^{1}$ denoting the number of treated observations within each cell defined by unemployment and treatment entry; $N_{c}^{1}$ denoting the number of treated by calendar month of unemployment entry, and $N^{1}$ denoting the total number of treated. After canceling $N_{c}^{1}$ out the total effect $\tau^{I P W}$ can be written as:

$$
\tau^{I P W}=\frac{1}{N^{1}} \sum_{c=1}^{12} \sum_{p=1}^{12} \tau_{c p}^{I P W} \cdot N_{c p}^{1} .
$$




\title{
Supplementary Appendix to
}

\section{"Fighting Youth Unemployment: The Effects of Active Labor Market Policies" \\ by}

\author{
Marco Caliendo, Steffen Künn and Ricarda Schmidl
}

This supplementary appendix provides additional information to the reviewer. In case of publication this appendix will be made publicly available by providing a download link on the author's web sites.

The supplementary appendix contains additional information to the following chapters in the paper:

Chapter 4.3: Table S.1 contains a more detailed account of the fit of the propensity score specification, by providing the hit rates of the estimated scores. Additionally, it depicts the number of observations deleted through the imposition of the "Min-Max" Common Support condition.

Chapter 4.4: Tables S.2 and S.3 provide detailed matching quality indicators for the different subgroups for East and West Germany respectively.

Chapter 5.2: Tables S.4 to S.8 provide details on the heterogeneity of results by gender and pre-treatment schooling level. While Table S.4 depicts the observation numbers across subgroups for the respective programs, the subsequent tables provide selected results of the treatment effect estimates. Tables S.5 (gender) and S.7 (schooling) show the ATTestimates for selected months after program entry; Tables S.6 (gender) and S.8 (schooling) provide the cumulative impact of program participation 30 and 60 months after program entry.

Chapter 5.3: Table S.9 provides the cumulative treatment effect estimates after 30 and 60 months for the different manipulations of the estimation process as part of the sensitivity analysis. 
Table S.1: Hit rates of predicted propensity scores and number of observations deleted in the Min-Max Common Support (CS)

\begin{tabular}{|c|c|c|c|c|c|c|c|c|c|}
\hline \multicolumn{10}{|c|}{ East Germany } \\
\hline Entry into & \multicolumn{3}{|c|}{ 1-3 months } & \multicolumn{3}{|c|}{ 4-6 months } & \multicolumn{3}{|c|}{ 7-12 months } \\
\hline & Hit Rate & CS NP & CS P & Hit Rate & CS NP & CS P & Hit Rate & CS NP & CS P \\
\hline JS & $68 \%$ & 762 & 0 & $71 \%$ & 968 & 2 & $72 \%$ & 1,179 & 0 \\
\hline STT & $67 \%$ & 511 & 0 & $68 \%$ & 428 & 0 & $70 \%$ & 1,364 & 1 \\
\hline JWS & $68 \%$ & 31 & 0 & $70 \%$ & 1,745 & 0 & $74 \%$ & 1,014 & 1 \\
\hline WS & $62 \%$ & 896 & 0 & $71 \%$ & 2,637 & 0 & $77 \%$ & 2,802 & 0 \\
\hline JCS & $72 \%$ & 107 & 0 & $71 \%$ & 2,747 & 1 & $71 \%$ & 411 & 5 \\
\hline $\mathrm{FT}$ & $67 \%$ & 2,292 & 0 & $74 \%$ & 3,137 & 1 & $76 \%$ & 2,663 & 0 \\
\hline $\mathrm{PT}$ & $77 \%$ & 2,873 & 0 & $75 \%$ & 3,276 & 0 & $79 \%$ & 2,815 & 0 \\
\hline \multicolumn{10}{|c|}{ West Germany } \\
\hline $\begin{array}{l}\text { Entry into } \\
\text { program }\end{array}$ & \multicolumn{3}{|c|}{ 1-3 months } & \multicolumn{3}{|c|}{ 4-6 months } & \multicolumn{3}{|c|}{ 7-12 months } \\
\hline & Hit Rate & CS NP & CS P & Hit Rate & CS NP & CS P & Hit Rate & CS NP & CS P \\
\hline JS & $65 \%$ & 191 & 0 & $67 \%$ & 2,296 & 0 & $69 \%$ & 2,002 & 0 \\
\hline STT & $64 \%$ & 113 & 1 & $66 \%$ & 44 & 0 & $68 \%$ & 1,515 & 1 \\
\hline JWS & $66 \%$ & 1,701 & 0 & $71 \%$ & 3,474 & 0 & $71 \%$ & 199 & 0 \\
\hline WS & $65 \%$ & 692 & 0 & $70 \%$ & 1,585 & 0 & $79 \%$ & 8,057 & 0 \\
\hline JCS & $74 \%$ & 6,348 & 0 & $73 \%$ & 3,159 & 0 & $73 \%$ & 4,853 & 0 \\
\hline $\mathrm{FT}$ & $64 \%$ & 679 & 0 & $72 \%$ & 4,260 & 0 & $73 \%$ & 4,032 & 0 \\
\hline $\mathrm{PT}$ & $73 \%$ & 6,607 & 0 & $70 \%$ & 299 & 0 & $74 \%$ & 2,800 & 0 \\
\hline
\end{tabular}

Note: The number of deleted observations for treated and controls are the sum of the respective upper and lower bound restrictions. Hit rate: Share of participants correctly predicted by the propensity score; CS NP: Number of non-participants deleted due to the imposition of the common support condition. CS P: Number of participants deleted due to the imposition of the common support condition.

Abbreviation index: JS: job search assistance; STT: short-term training; JWS: JUMP wage subsidies; WS: $S G B$ III wage subsidies; FT: further training (medium to long-term); PT: preparatory training; NP: nonparticipants. 
Table S.2: Matching quality: balancing quality of IPW in East Germany - different indicators

\begin{tabular}{|c|c|c|c|c|c|c|c|c|}
\hline Program & & JS & STT & JWS & WS & FT & JCS & $\mathrm{PT}$ \\
\hline & \multicolumn{8}{|c|}{ Entries between 1 to 3 months in unemployment } \\
\hline & \multicolumn{8}{|c|}{ t-test on equal means } \\
\hline Unmatched & \multirow[t]{2}{*}{$1 \%$-level } & 33 & 20 & 31 & 19 & 25 & 17 & 26 \\
\hline Matched & & 0 & 0 & 0 & 0 & 0 & 0 & 0 \\
\hline Unmatched & \multirow[t]{2}{*}{$5 \%$-level } & 39 & 26 & 35 & 24 & 30 & 24 & 29 \\
\hline Matched & & 0 & 0 & 0 & 0 & 0 & 0 & 0 \\
\hline Unmatched & \multirow[t]{2}{*}{$10 \%$-level } & 42 & 30 & 41 & 26 & 34 & 27 & 35 \\
\hline \multirow[t]{2}{*}{ Matched } & & 0 & 0 & 0 & 0 & 0 & 1 & 0 \\
\hline & \multicolumn{8}{|c|}{ Mean standardized bias } \\
\hline \multirow{4}{*}{$\begin{array}{l}\text { Unmatched } \\
\text { Matched }\end{array}$} & & 19.93 & 12.88 & 23.34 & 14.73 & 21.60 & 15.66 & 23.65 \\
\hline & & 0.85 & 1.22 & 1.06 & 0.83 & 1.53 & 1.59 & 1.76 \\
\hline & \multicolumn{8}{|c|}{ Entries between 4 to 6 months in unemployment } \\
\hline & \multicolumn{8}{|c|}{ t-test on equal means } \\
\hline Unmatched & \multirow[t]{2}{*}{ 1\%-level } & 34 & 31 & 26 & 8 & 12 & 18 & 7 \\
\hline Matched & & 0 & 0 & 0 & 0 & 0 & 0 & 0 \\
\hline Unmatched & \multirow[t]{2}{*}{$5 \%$-level } & 35 & 34 & 30 & 16 & 12 & 21 & 13 \\
\hline Matched & & 0 & 0 & 0 & 0 & 0 & 0 & 0 \\
\hline Unmatched & \multirow[t]{2}{*}{$10 \%$-level } & 37 & 34 & 33 & 24 & 19 & 25 & 18 \\
\hline \multirow[t]{2}{*}{ Matched } & & 0 & 0 & 0 & 0 & 0 & 1 & 0 \\
\hline & \multicolumn{8}{|c|}{ Mean standardized bias } \\
\hline \multirow{4}{*}{$\begin{array}{l}\text { Unmatched } \\
\text { Matched } \\
\end{array}$} & & 26.94 & 23.16 & 21.81 & 17.30 & 12.38 & 18.11 & 14.29 \\
\hline & & 1.17 & 0.97 & 1.05 & 1.27 & 1.31 & 1.61 & 2.00 \\
\hline & \multicolumn{8}{|c|}{ Entries between 7 to 12 months in unemployment } \\
\hline & \multicolumn{8}{|c|}{ t-test on equal means } \\
\hline Unmatched & \multirow[t]{2}{*}{$1 \%$-level } & 33 & 26 & 28 & 16 & 30 & 12 & 14 \\
\hline Matched & & 0 & 0 & 0 & 0 & 0 & 0 & 0 \\
\hline Unmatched & \multirow{2}{*}{ 5\%-level } & 37 & 35 & 31 & 22 & 35 & 24 & 22 \\
\hline Matched & & 0 & 0 & 0 & 0 & 0 & 0 & 0 \\
\hline Unmatched & \multirow[t]{2}{*}{$10 \%$-level } & 40 & 39 & 35 & 26 & 43 & 31 & 25 \\
\hline \multirow[t]{2}{*}{ Matched } & & 0 & 0 & 0 & 0 & 0 & 1 & 0 \\
\hline & \multicolumn{8}{|c|}{ Mean standardized bias } \\
\hline Unmatched & & 24.10 & 19.67 & 29.55 & 23.84 & 19.31 & 21.22 & 17.98 \\
\hline Matched & & 1.58 & 1.36 & 1.48 & 2.81 & 1.35 & 2.67 & 2.18 \\
\hline
\end{tabular}

Note: For the t-test we conducted a simple t-test on the comparison of equal means. Depicted are the number of covariates with significant differences across the two groups, at the respective significance level. We included all variables in the analysis that were used in the respective PS-specifications - the baseline specification contains a total number of 53 covariates.

Abbreviation index: JS: job search assistance; STT: short-term training; JWS: JUMP wage subsidies; WS: $S G B I I I$ wage subsidies; FT: further training (medium to longterm); PT: preparatory training; NP: non-participants. 
Table S.3: Matching quality: balancing quality of IPW in West Germany - different indicators

\begin{tabular}{|c|c|c|c|c|c|c|c|c|}
\hline Program & & JS & $\overline{\mathrm{STT}}$ & JWS & $\overline{\mathrm{WS}}$ & 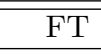 & JCS & $\overline{\mathrm{PT}}$ \\
\hline & \multicolumn{8}{|c|}{ Entries between 1 to 3 months in unemployment } \\
\hline & \multicolumn{8}{|c|}{ t-test on equal means } \\
\hline Unmatched & \multirow[t]{2}{*}{$1 \%$-level } & 28 & 31 & 22 & 17 & 28 & 24 & 41 \\
\hline Matched & & 0 & 0 & 0 & 0 & 0 & 0 & 0 \\
\hline Unmatched & \multirow[t]{2}{*}{$5 \%$-level } & 31 & 35 & 29 & 25 & 33 & 31 & 43 \\
\hline matched & & 0 & 0 & 0 & 0 & 0 & 0 & 0 \\
\hline Unmatched & \multirow[t]{2}{*}{$10 \%$-level } & 33 & 36 & 36 & 27 & 35 & 37 & 45 \\
\hline \multirow[t]{2}{*}{ Matched } & & 0 & 0 & 0 & 0 & 0 & 0 & 0 \\
\hline & \multicolumn{8}{|c|}{ Mean standardized bias } \\
\hline \multirow{4}{*}{$\begin{array}{l}\text { Unmatched } \\
\text { Matched }\end{array}$} & & 11.68 & 10.28 & 13.87 & 11.23 & 18.69 & 15.71 & 22.73 \\
\hline & & 0.52 & 1.01 & 0.64 & 0.60 & 1.60 & 1.08 & 1.13 \\
\hline & \multicolumn{8}{|c|}{ Entries between 4 to 6 months in unemployment } \\
\hline & \multicolumn{8}{|c|}{ t-test on equal means } \\
\hline \multirow{7}{*}{$\begin{array}{l}\text { Unmatched } \\
\text { Matched } \\
\text { Unmatched } \\
\text { matched } \\
\text { Unmatched } \\
\text { Matched }\end{array}$} & \multirow[t]{2}{*}{ 1\%-level } & 33 & 30 & 20 & 20 & 11 & 19 & 27 \\
\hline & & 0 & 0 & 0 & 0 & 0 & 0 & 0 \\
\hline & \multirow{2}{*}{$5 \%$-level } & 37 & 37 & 27 & 26 & 15 & 24 & 36 \\
\hline & & 0 & 0 & 0 & 0 & 0 & 0 & 0 \\
\hline & \multirow{2}{*}{$10 \%$-level } & 39 & 38 & 30 & 29 & 21 & 32 & 38 \\
\hline & & 0 & 0 & 0 & 0 & 0 & 1 & 1 \\
\hline & \multicolumn{8}{|c|}{ Mean standardized bias } \\
\hline \multirow{4}{*}{$\begin{array}{l}\text { Unmatched } \\
\text { Matched }\end{array}$} & & 18.31 & 17.93 & 17.17 & 20.54 & 14.68 & 21.52 & 25.43 \\
\hline & & 0.71 & 0.60 & 1.05 & 1.23 & 1.81 & 1.78 & 1.15 \\
\hline & \multicolumn{8}{|c|}{ Entries between 7 to 12 months in unemployment } \\
\hline & \multicolumn{8}{|c|}{ t-test on equal means } \\
\hline Unmatched & \multirow[t]{2}{*}{ 1\%-level } & 34 & 33 & 27 & 5 & 15 & 19 & 20 \\
\hline Matched & & 0 & 0 & 0 & 0 & 0 & 0 & 0 \\
\hline Unmatched & \multirow[t]{2}{*}{$5 \%$-level } & 38 & 36 & 32 & 7 & 22 & 22 & 25 \\
\hline Matched & & 0 & 0 & 0 & 0 & 0 & 0 & 0 \\
\hline Unmatched & \multirow[t]{2}{*}{$10 \%$-level } & 42 & 38 & 36 & 15 & 28 & 23 & 29 \\
\hline \multirow[t]{2}{*}{ Matched } & & 0 & 0 & 0 & 0 & 0 & 1 & 0 \\
\hline & \multicolumn{8}{|c|}{ Mean standardized bias } \\
\hline Unmatched & & 19.58 & 20.01 & 26.60 & 15.43 & 13.81 & 19.22 & 19.19 \\
\hline Matched & & 0.93 & 0.61 & 1.75 & 2.63 & 1.00 & 1.79 & 1.36 \\
\hline
\end{tabular}

Note: For the t-test we conducted a simple t-test on the comparison of equal means. Depicted are the number of covariates with significant differences across the two groups, at the respective significance level. We included all variables in the analysis that were used in the respective PS-specifications - the baseline specification contains a total number of 53 covariates.

Abbreviation index: JS: job search assistance; STT: short-term training; JWS: JUMP

wage subsidies; WS: SGB III wage subsidies; FT: further training (medium to longterm); PT: preparatory training; NP: non-participants. 
Table S.4: Number of observations by gender and pre-treatment schooling levels for program participants and non-participants

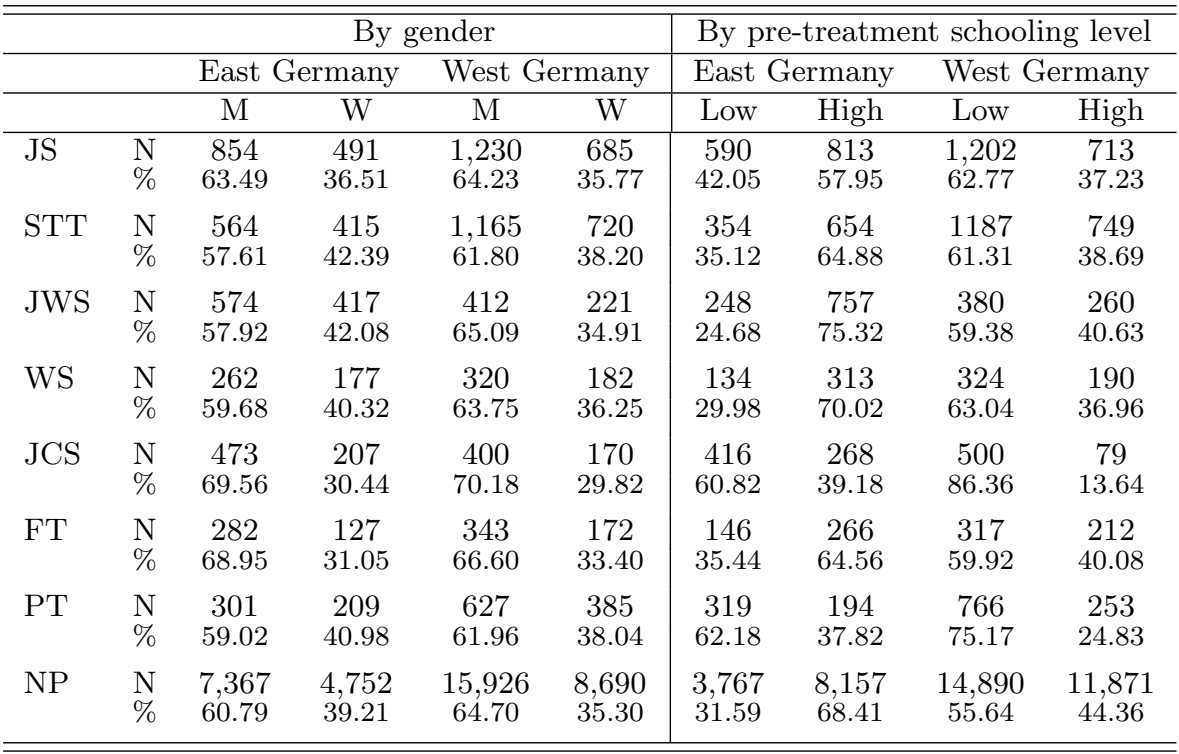

Source: Calculations are based on the estimation sample.

Note: Low levels of schooling indicate a lower secondary schooling degree levels or none; high levels of schooling indicate a medium or higher secondary schooling degree.

Abbreviation index: JS: job search assistance; STT: short-term training; JWS: JUMP wage subsidies; WS: $S G B$ III wage subsidies; FT: further training (medium to longterm); PT: preparatory training; NP: non-participants. 
Table S.5: Treatment effect heterogeneity by gender - selected monthly employment effects.

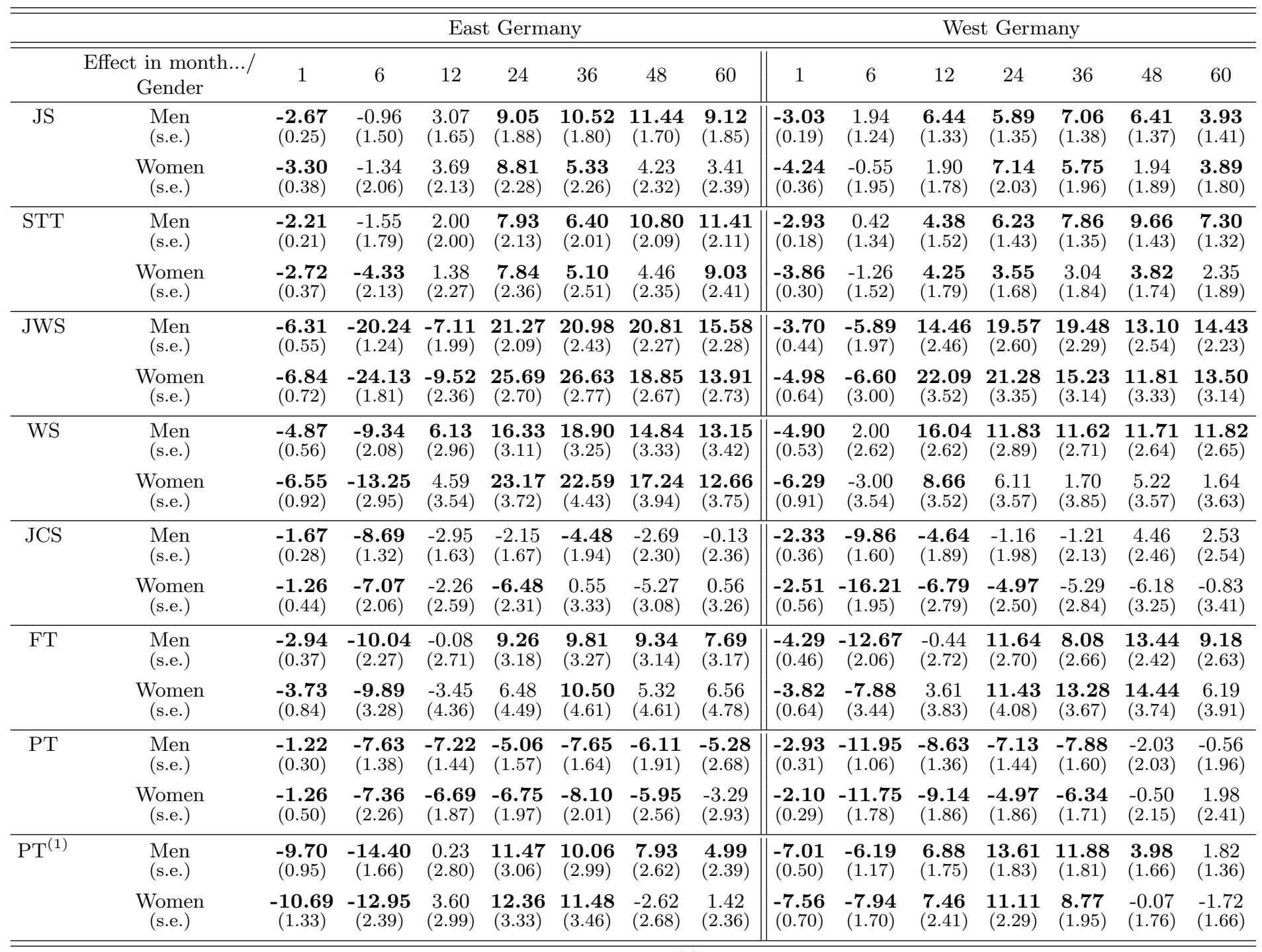

Note: Depicted are monthly ATT estimates on employment probabilities. (1) refers to the ATT estimates on the education probabilities. The ATT are written in bold when they are significant at conventional 5\%-level. Standard errors are obtained by bootstrapping with 200 replications and are depicted in parentheses.

Abbreviation index: JS: job search assistance; STT: short-term training; JWS: JUMP wage subsidies; WS: SGB III wage subsidies; FT: further training (medium to long-term); PT: preparatory training; NP: non-participants. 
Table S.6: Treatment effect heterogeneity by gender - cumulated effects after 30 and 60 months.

\begin{tabular}{|c|c|c|c|c|c|c|c|c|c|}
\hline & & \multicolumn{4}{|c|}{ East Germany } & \multicolumn{4}{|c|}{ West Germany } \\
\hline & & \multicolumn{2}{|c|}{ Employment } & \multicolumn{2}{|c|}{ Education } & \multicolumn{2}{|c|}{ Employment } & \multicolumn{2}{|c|}{ Education } \\
\hline & $\begin{array}{c}\sum / \\
\text { Gender }\end{array}$ & 30 & 60 & 30 & 60 & 30 & 60 & 30 & 60 \\
\hline \multirow[t]{2}{*}{ JS } & $\begin{array}{l}\text { Men } \\
\text { (s.e) }\end{array}$ & $\begin{array}{l}\mathbf{1 . 3 9} \\
(0.35)\end{array}$ & $\begin{array}{c}\mathbf{4 . 1 9} \\
(0.68)\end{array}$ & $\begin{array}{r}\mathbf{- 0 . 9 1} \\
(0.19)\end{array}$ & $\begin{array}{r}\mathbf{- 1 . 5 1} \\
(0.36)\end{array}$ & $\begin{array}{l}\mathbf{1 . 3 9} \\
(0.26)\end{array}$ & $\begin{array}{l}\mathbf{3 . 0 6} \\
(0.54)\end{array}$ & $\begin{array}{r}-\mathbf{- 1 . 0 1} \\
(0.17)\end{array}$ & $\begin{array}{c}\mathbf{- 1 . 5 2} \\
(0.30)\end{array}$ \\
\hline & $\begin{array}{c}\text { Women } \\
\text { (s.e) }\end{array}$ & $\begin{array}{l}\mathbf{1 . 4 4} \\
(0.44)\end{array}$ & $\begin{array}{l}\mathbf{2 . 7 4} \\
(0.86)\end{array}$ & $\begin{array}{r}\mathbf{- 1 . 5 3} \\
(0.26)\end{array}$ & $\begin{array}{l}\mathbf{- 1 . 8 5} \\
(0.49)\end{array}$ & $\begin{array}{l}\mathbf{1 . 1 6} \\
(0.41)\end{array}$ & $\begin{array}{l}\mathbf{2 . 1 5} \\
(0.79)\end{array}$ & $\begin{array}{r}\mathbf{- 0 . 9 8} \\
(0.26)\end{array}$ & $\begin{array}{r}\mathbf{- 1 . 2 1} \\
(0.44)\end{array}$ \\
\hline \multirow[t]{2}{*}{$\mathrm{STT}$} & $\begin{array}{l}\text { Men } \\
\text { (s.e) }\end{array}$ & $\begin{array}{l}\mathbf{1 . 2 3} \\
(0.40)\end{array}$ & $\begin{array}{l}\mathbf{4 . 0 2} \\
(0.81)\end{array}$ & $\begin{array}{r}\mathbf{- 1 . 2 9} \\
(0.23)\end{array}$ & $\begin{array}{r}\mathbf{- 1 . 8 2} \\
(0.41)\end{array}$ & $\begin{array}{l}\mathbf{1 . 1 4} \\
(0.29)\end{array}$ & $\begin{array}{l}\mathbf{3 . 5 6} \\
(0.55)\end{array}$ & $\begin{array}{c}\mathbf{- 1 . 1 4} \\
(0.18)\end{array}$ & $\begin{array}{c}\mathbf{- 1 . 5 6} \\
(0.31)\end{array}$ \\
\hline & $\begin{array}{l}\text { Women } \\
\text { (s.e) }\end{array}$ & $\begin{array}{l}\mathbf{1 . 0 0} \\
(0.50)\end{array}$ & $\begin{array}{c}\mathbf{2 . 7 1} \\
(0.90)\end{array}$ & $\begin{array}{r}\mathbf{- 1 . 4 2} \\
(0.31)\end{array}$ & $\begin{array}{r}\mathbf{- 1 . 5 3} \\
(0.58)\end{array}$ & $\begin{array}{l}\mathbf{0 . 6 7} \\
(0.34)\end{array}$ & $\begin{array}{l}\mathbf{1 . 4 2} \\
(0.68)\end{array}$ & $\begin{array}{r}\mathbf{- 0 . 7 8} \\
(0.26)\end{array}$ & $\begin{array}{l}-0.83 \\
(0.47)\end{array}$ \\
\hline \multirow[t]{2}{*}{ JWS } & $\begin{array}{l}\text { Men } \\
\text { (s.e) }\end{array}$ & $\begin{array}{l}\mathbf{2 . 7 0} \\
(0.39)\end{array}$ & $\begin{array}{l}\mathbf{8 . 4 9} \\
(0.84)\end{array}$ & $\begin{array}{c}\mathbf{- 2 . 1 4} \\
(0.18)\end{array}$ & $\begin{array}{r}\mathbf{- 3 . 6 3} \\
(0.38)\end{array}$ & $\begin{array}{l}\mathbf{4 . 1 3} \\
(0.46)\end{array}$ & $\begin{array}{l}\mathbf{8 . 9 6} \\
(0.91)\end{array}$ & $\begin{array}{l}\mathbf{- 2 . 2 1} \\
(0.18)\end{array}$ & $\begin{array}{r}\mathbf{- 3 . 4 2} \\
(0.38)\end{array}$ \\
\hline & $\begin{array}{r}\text { Wom } \\
\text { (s.e) }\end{array}$ & $\begin{array}{l}\mathbf{3 . 2 4} \\
(0.48)\end{array}$ & $\begin{array}{l}\mathbf{9 . 4 4} \\
(0.96)\end{array}$ & $\begin{array}{l}\mathbf{- 2 . 6 5} \\
(0.25)\end{array}$ & $\begin{array}{r}\mathbf{- 3 . 7 3} \\
(0.44)\end{array}$ & $\begin{array}{l}4.31 \\
(0.62)\end{array}$ & $\begin{array}{l}\mathbf{9 . 4 2} \\
(1.30)\end{array}$ & $\begin{array}{r}\mathbf{- 2 . 3 2} \\
(0.34)\end{array}$ & $\begin{array}{r}\mathbf{- 3 . 3 0} \\
(0.66)\end{array}$ \\
\hline \multirow[t]{2}{*}{ WS } & $\begin{array}{l}\text { Men } \\
\text { (s.e) }\end{array}$ & $\begin{array}{l}\mathbf{3 . 4 2} \\
(0.57)\end{array}$ & $\begin{array}{l}\mathbf{8 . 2 8} \\
(1.25)\end{array}$ & $\begin{array}{r}\mathbf{- 1 . 6 6} \\
(0.28)\end{array}$ & $\begin{array}{r}\mathbf{- 3 . 1 1} \\
(0.49)\end{array}$ & $\begin{array}{c}\mathbf{2 . 8 9} \\
(0.52)\end{array}$ & $\begin{array}{c}\mathbf{6 . 0 3} \\
(1.03)\end{array}$ & $\begin{array}{l}\mathbf{- 1 . 2 7} \\
(0.29)\end{array}$ & $\begin{array}{r}\mathbf{- 2 . 3 2} \\
(0.48)\end{array}$ \\
\hline & $\begin{array}{c}\text { Women } \\
\text { (s.e) }\end{array}$ & $\begin{array}{l}4.23 \\
(0.66)\end{array}$ & $\begin{array}{l}\mathbf{9 . 7 7} \\
(1.46)\end{array}$ & $\begin{array}{r}\mathbf{- 3 . 0 9} \\
(0.40)\end{array}$ & $\begin{array}{l}-4.23 \\
(0.70)\end{array}$ & $\begin{array}{l}\mathbf{1 . 4 3} \\
(0.76)\end{array}$ & $\begin{array}{c}2.28 \\
(1.46)\end{array}$ & $\begin{array}{r}\mathbf{- 1 . 4 2} \\
(0.45)\end{array}$ & $\begin{array}{r}\mathbf{- 1 . 8 1} \\
(0.88)\end{array}$ \\
\hline \multirow[t]{2}{*}{ JCS } & $\begin{array}{l}\text { Men } \\
\text { (s.e) }\end{array}$ & $\begin{array}{r}\mathbf{- 1 . 3 6} \\
(0.30)\end{array}$ & $\begin{array}{l}\mathbf{- 2 . 2 6} \\
(0.73)\end{array}$ & $\begin{array}{r}\mathbf{- 1 . 3 6} \\
(0.28)\end{array}$ & $\begin{array}{l}\mathbf{- 1 . 3 8} \\
(0.52)\end{array}$ & $\begin{array}{l}\mathbf{- 0 . 9 9} \\
(0.34)\end{array}$ & $\begin{array}{l}-0.57 \\
(0.78)\end{array}$ & $\begin{array}{l}-\mathbf{- 0 . 8 1} \\
(0.29)\end{array}$ & $\begin{array}{l}-0.66 \\
(0.56)\end{array}$ \\
\hline & $\begin{array}{c}\text { Women } \\
\text { (s.e) }\end{array}$ & $\begin{array}{r}\mathbf{- 1 . 4 6} \\
(0.47)\end{array}$ & $\begin{array}{l}\mathbf{- 2 . 1 6} \\
(1.05)\end{array}$ & $\begin{array}{l}\mathbf{- 2 . 0 5} \\
(0.49)\end{array}$ & $\begin{array}{l}\mathbf{- 2 . 8 7} \\
(0.81)\end{array}$ & $\begin{array}{l}\mathbf{- 2 . 2 8} \\
(0.49)\end{array}$ & $\begin{array}{l}\mathbf{- 3 . 8 6} \\
(0.99)\end{array}$ & $\begin{array}{l}-\mathbf{- 1 . 3 0} \\
(0.47)\end{array}$ & $\begin{array}{l}-0.99 \\
(0.99)\end{array}$ \\
\hline \multirow[t]{2}{*}{$\mathrm{FT}$} & $\begin{array}{l}\text { Men } \\
\text { (s.e) }\end{array}$ & $\begin{array}{c}0.64 \\
(0.56)\end{array}$ & $\begin{array}{c}\mathbf{3 . 5 7} \\
(1.18)\end{array}$ & $\begin{array}{r}\mathbf{- 1 . 9 1} \\
(0.30)\end{array}$ & $\begin{array}{l}\mathbf{- 3 . 1 8} \\
(0.55)\end{array}$ & $\begin{array}{c}0.84 \\
(0.50)\end{array}$ & $\begin{array}{c}\mathbf{3 . 8 5} \\
(0.94)\end{array}$ & $\begin{array}{l}\mathbf{- 1 . 8 5} \\
(0.27)\end{array}$ & $\begin{array}{l}\mathbf{- 2 . 4 8} \\
(0.52)\end{array}$ \\
\hline & $\begin{array}{c}\text { Women } \\
\text { (s.e) }\end{array}$ & $\begin{array}{l}-0.26 \\
(0.85)\end{array}$ & $\begin{array}{c}1.66 \\
(1.78)\end{array}$ & $\begin{array}{r}\mathbf{- 2 . 2 9} \\
(0.41)\end{array}$ & $\begin{array}{c}\mathbf{- 2 . 9 8} \\
(0.72)\end{array}$ & $\begin{array}{l}\mathbf{1 . 7 9} \\
(0.80)\end{array}$ & $\begin{array}{c}\mathbf{5 . 3 7} \\
(1.57)\end{array}$ & $\begin{array}{r}\mathbf{- 2 . 2 8} \\
(0.39)\end{array}$ & $\begin{array}{c}\mathbf{- 3 . 0 8} \\
(0.74)\end{array}$ \\
\hline \multirow[t]{2}{*}{$\mathrm{PT}$} & $\begin{array}{l}\text { Men } \\
\text { (s.e) }\end{array}$ & $\begin{array}{l}\mathbf{- 1 . 7 0} \\
(0.30)\end{array}$ & $\begin{array}{l}\mathbf{- 3 . 4 2} \\
(0.64)\end{array}$ & $\begin{array}{c}0.60 \\
(0.63)\end{array}$ & $\begin{array}{l}\mathbf{2 . 8 5} \\
(1.03)\end{array}$ & $\begin{array}{l}\mathbf{- 2 . 2 3} \\
(0.26)\end{array}$ & $\begin{array}{l}\mathbf{- 3 . 5 5} \\
(0.59)\end{array}$ & $\begin{array}{l}\mathbf{1 . 6 5} \\
(0.36)\end{array}$ & $\begin{array}{l}\mathbf{3 . 7 4} \\
(0.62)\end{array}$ \\
\hline & $\begin{array}{c}\text { Women } \\
\text { (s.e) }\end{array}$ & $\begin{array}{r}\mathbf{- 1 . 6 6} \\
(0.41)\end{array}$ & $\begin{array}{r}\mathbf{- 3 . 5 4} \\
(0.79)\end{array}$ & $\begin{array}{c}0.62 \\
(0.64)\end{array}$ & $\begin{array}{l}\mathbf{1 . 8 9} \\
(1.06)\end{array}$ & $\begin{array}{c}\mathbf{- 2 . 0 6} \\
(0.38)\end{array}$ & $\begin{array}{c}\mathbf{- 2 . 6 9} \\
(0.75)\end{array}$ & $\begin{array}{l}\mathbf{1 . 2 6} \\
(0.50)\end{array}$ & $\begin{array}{c}\mathbf{2 . 3 3} \\
(0.76)\end{array}$ \\
\hline
\end{tabular}

Note: Depicted are the cumulated treatment effects, summing up the monthly ATT between for 30 or 60 months following treatment entry. The effects are written in bold when they are significant at conventional 5\%-level. Standard errors are obtained by bootstrapping with 200 replications and are depicted in parentheses.

Abbreviation index: JS: job search assistance; STT: short-term training; JWS: JUMP wage subsidies; WS: SGB III wage subsidies; FT: further training (medium to long-term); PT: preparatory training; NP: non-participants. 
Table S.7: Treatment effect heterogeneity by pretreatment schooling - selected monthly employment effects.

\begin{tabular}{|c|c|c|c|c|c|c|c|c|c|c|c|c|c|c|c|}
\hline & \multirow[b]{2}{*}{$\begin{array}{c}\text { Effect in month.../ } \\
\text { Education }\end{array}$} & \multicolumn{7}{|c|}{ East Germany } & \multicolumn{7}{|c|}{ West Germany } \\
\hline & & 1 & 6 & 12 & 24 & 36 & 48 & 60 & 1 & 6 & 12 & 24 & 36 & 48 & 60 \\
\hline \multirow[t]{2}{*}{ JS } & $\begin{array}{l}\text { Low } \\
\text { (s.e.) }\end{array}$ & $\begin{array}{l}\mathbf{- 2 . 3 1} \\
(0.29)\end{array}$ & $\begin{array}{c}0.11 \\
(1.69)\end{array}$ & $\begin{array}{l}4.47 \\
(1.90)\end{array}$ & $\begin{array}{c}\mathbf{7 . 0 1} \\
(1.96)\end{array}$ & $\begin{array}{l}\mathbf{9 . 2 6} \\
(1.97)\end{array}$ & $\begin{array}{l}\mathbf{6 . 9 1} \\
(1.98)\end{array}$ & $\begin{array}{l}\mathbf{5 . 3 4} \\
(2.05)\end{array}$ & $\begin{array}{l}\mathbf{- 2 . 8 0} \\
(0.21)\end{array}$ & $\begin{array}{c}0.75 \\
(1.35)\end{array}$ & $\begin{array}{c}\mathbf{4 . 1 7} \\
(1.33)\end{array}$ & $\begin{array}{l}\mathbf{4 . 9 6} \\
(1.29)\end{array}$ & $\begin{array}{l}\mathbf{4 . 7 6} \\
(1.48)\end{array}$ & $\begin{array}{l}\mathbf{3 . 0 4} \\
(1.36)\end{array}$ & $\begin{array}{c}\mathbf{3 . 3 1} \\
(1.51)\end{array}$ \\
\hline & $\begin{array}{l}\text { High } \\
\text { (s.e.) }\end{array}$ & $\begin{array}{r}\mathbf{- 3 . 3 7} \\
(0.27)\end{array}$ & $\begin{array}{c}2.00 \\
(1.42)\end{array}$ & $\begin{array}{c}\mathbf{6 . 7 8} \\
(1.78)\end{array}$ & $\begin{array}{c}\mathbf{1 4 . 3 8} \\
(1.98)\end{array}$ & $\begin{array}{l}\mathbf{1 1 . 9 9} \\
(1.96)\end{array}$ & $\begin{array}{c}\mathbf{1 3 . 0 2} \\
(1.94)\end{array}$ & $\begin{array}{c}\mathbf{9 . 5 8} \\
(1.93)\end{array}$ & $\begin{array}{c}-4.68 \\
(0.40)\end{array}$ & $\begin{array}{l}1.62 \\
(1.78)\end{array}$ & $\begin{array}{c}\mathbf{6 . 7 9} \\
(1.81)\end{array}$ & $\begin{array}{c}\mathbf{8 . 7 4} \\
(1.90)\end{array}$ & $\begin{array}{c}\mathbf{9 . 8 3} \\
(1.91)\end{array}$ & $\begin{array}{l}\mathbf{8 . 0 7} \\
(2.04)\end{array}$ & $\begin{array}{c}\mathbf{6 . 0 4} \\
(2.08)\end{array}$ \\
\hline \multirow[t]{2}{*}{ STT } & $\begin{array}{l}\text { Low } \\
\text { (s.e.) }\end{array}$ & $\begin{array}{r}\mathbf{- 1 . 7 5} \\
(0.23)\end{array}$ & $\begin{array}{l}-1.37 \\
(1.61)\end{array}$ & $\begin{array}{c}1.46 \\
(1.92)\end{array}$ & $\begin{array}{l}\mathbf{7 . 3 8} \\
(2.43)\end{array}$ & $\begin{array}{l}4.75 \\
(2.55)\end{array}$ & $\begin{array}{c}\mathbf{6 . 4 0} \\
(2.65)\end{array}$ & $\begin{array}{l}\mathbf{1 1 . 8 4} \\
(2.87)\end{array}$ & $\begin{array}{l}\mathbf{- 2 . 7 0} \\
(0.16)\end{array}$ & $\begin{array}{c}2.18 \\
(1.15)\end{array}$ & $\begin{array}{c}\mathbf{6 . 2 1} \\
(1.36)\end{array}$ & $\begin{array}{c}\mathbf{6 . 1 5} \\
(1.31)\end{array}$ & $\begin{array}{c}\mathbf{6 . 7 0} \\
(1.46)\end{array}$ & $\begin{array}{l}\mathbf{9 . 0 7} \\
(1.47)\end{array}$ & $\begin{array}{r}\mathbf{7 . 1 3} \\
(1.48)\end{array}$ \\
\hline & $\begin{array}{l}\text { High } \\
\text { (s.e.) }\end{array}$ & $\begin{array}{c}\mathbf{- 2 . 6 6} \\
(0.24)\end{array}$ & $\begin{array}{c}0.53 \\
(1.65)\end{array}$ & $\begin{array}{c}\mathbf{5 . 9 0} \\
(1.90)\end{array}$ & $\begin{array}{c}\mathbf{1 2 . 3 7} \\
(2.05)\end{array}$ & $\begin{array}{c}\mathbf{1 0 . 1 7} \\
(2.12)\end{array}$ & $\begin{array}{c}\mathbf{1 2 . 2 0} \\
(2.11)\end{array}$ & $\begin{array}{c}\mathbf{1 0 . 6 8} \\
(2.03)\end{array}$ & $\begin{array}{c}\mathbf{- 3 . 7 5} \\
(0.28)\end{array}$ & $\begin{array}{l}\mathbf{4 . 1 7} \\
(1.71)\end{array}$ & $\begin{array}{c}\mathbf{8 . 5 0} \\
(1.70)\end{array}$ & $\begin{array}{c}\mathbf{1 0 . 0 4} \\
(1.72)\end{array}$ & $\begin{array}{l}\mathbf{9 . 1 9} \\
(1.70)\end{array}$ & $\begin{array}{l}\mathbf{8 . 3 4} \\
(1.81)\end{array}$ & $\begin{array}{l}\mathbf{5 . 5 4} \\
(1.65)\end{array}$ \\
\hline \multirow[t]{2}{*}{ JWS } & $\begin{array}{l}\text { Low } \\
\text { (s.e.) }\end{array}$ & $\begin{array}{r}-\mathbf{5 . 2 2} \\
(0.67)\end{array}$ & $\begin{array}{c}\mathbf{- 1 5 . 2 6} \\
(1.86)\end{array}$ & $\begin{array}{c}0.46 \\
(2.93)\end{array}$ & $\begin{array}{c}\mathbf{2 5 . 0 2} \\
(3.40)\end{array}$ & $\begin{array}{c}\mathbf{2 4 . 2 1} \\
(3.59)\end{array}$ & $\begin{array}{c}\mathbf{2 2 . 6 3} \\
(3.51)\end{array}$ & $\begin{array}{c}\mathbf{1 7 . 7 4} \\
(3.46)\end{array}$ & $\begin{array}{l}\mathbf{- 3 . 3 7} \\
(0.43)\end{array}$ & $\begin{array}{l}-2.32 \\
(2.30)\end{array}$ & $\begin{array}{c}\mathbf{1 6 . 2 3} \\
(2.61)\end{array}$ & $\begin{array}{c}\mathbf{1 5 . 9 5} \\
(2.35)\end{array}$ & $\begin{array}{c}\mathbf{1 3 . 1 3} \\
(2.36)\end{array}$ & $\begin{array}{l}\mathbf{1 2 . 3 4} \\
(2.42)\end{array}$ & $\begin{array}{c}\mathbf{1 2 . 3 3} \\
(2.21)\end{array}$ \\
\hline & $\begin{array}{l}\text { High } \\
\text { (s.e.) }\end{array}$ & $\begin{array}{r}\mathbf{- 6 . 8 0} \\
(0.45)\end{array}$ & $\begin{array}{c}\mathbf{- 1 9 . 9 5} \\
(0.98)\end{array}$ & $\begin{array}{l}-\mathbf{- 7 . 7 6} \\
(1.63)\end{array}$ & $\begin{array}{r}\mathbf{2 5 . 2 7} \\
(2.09)\end{array}$ & $\begin{array}{c}\mathbf{2 4 . 9 3} \\
(1.90)\end{array}$ & $\begin{array}{c}\mathbf{2 0 . 0 5} \\
(1.86)\end{array}$ & $\begin{array}{c}\mathbf{1 4 . 8 9} \\
(1.72)\end{array}$ & $\begin{array}{l}-4.76 \\
(0.71)\end{array}$ & $\begin{array}{l}\mathbf{- 9 . 1 0} \\
(2.59)\end{array}$ & $\begin{array}{c}\mathbf{2 0 . 4 0} \\
(3.25)\end{array}$ & $\begin{array}{r}\mathbf{2 7 . 2 7} \\
(3.31)\end{array}$ & $\begin{array}{c}\mathbf{2 5 . 8 3} \\
(3.02)\end{array}$ & $\begin{array}{l}\mathbf{1 2 . 8 9} \\
(3.13)\end{array}$ & $\begin{array}{r}\mathbf{1 5 . 3 9} \\
(3.07)\end{array}$ \\
\hline \multirow[t]{2}{*}{ WS } & $\begin{array}{l}\text { Low } \\
\text { (s.e.) }\end{array}$ & $\begin{array}{c}\mathbf{- 3 . 1 8} \\
(0.56)\end{array}$ & $\begin{array}{l}\mathbf{- 6 . 4 1} \\
(2.70)\end{array}$ & $\begin{array}{c}5.53 \\
(3.55)\end{array}$ & $\begin{array}{c}\mathbf{1 7 . 4 5} \\
(3.72)\end{array}$ & $\begin{array}{c}\mathbf{1 4 . 8 6} \\
(3.37)\end{array}$ & $\begin{array}{c}6.66 \\
(3.66)\end{array}$ & $\begin{array}{c}7.96 \\
(4.24)\end{array}$ & $\begin{array}{l}-\mathbf{- 4 . 0 9} \\
(0.42)\end{array}$ & $\begin{array}{c}2.33 \\
(2.21)\end{array}$ & $\begin{array}{l}\mathbf{1 2 . 9 6} \\
(2.62)\end{array}$ & $\begin{array}{l}\mathbf{8 . 6 6} \\
(2.61)\end{array}$ & $\begin{array}{l}\mathbf{7 . 9 5} \\
(2.37)\end{array}$ & $\begin{array}{l}\mathbf{8 . 8 7} \\
(2.43)\end{array}$ & $\begin{array}{l}\mathbf{9 . 8 8} \\
(2.61)\end{array}$ \\
\hline & $\begin{array}{l}\text { High } \\
\text { (s.e.) }\end{array}$ & $\begin{array}{r}\mathbf{- 6 . 8 1} \\
(0.61)\end{array}$ & $\begin{array}{c}-\mathbf{1 1 . 2 6} \\
(2.03)\end{array}$ & $\begin{array}{l}\mathbf{7 . 9 8} \\
(2.81)\end{array}$ & $\begin{array}{c}\mathbf{2 0 . 0 9} \\
(2.70)\end{array}$ & $\begin{array}{c}\mathbf{2 2 . 4 6} \\
(2.79)\end{array}$ & $\begin{array}{c}\mathbf{1 8 . 9 4} \\
(2.88)\end{array}$ & $\begin{array}{l}\mathbf{1 5 . 3 7} \\
(2.77)\end{array}$ & $\begin{array}{l}\mathbf{- 6 . 9 8} \\
(0.69)\end{array}$ & $\begin{array}{l}5.47 \\
(3.43)\end{array}$ & $\begin{array}{c}\mathbf{2 3 . 0 1} \\
(3.54)\end{array}$ & $\begin{array}{c}\mathbf{1 9 . 5 8} \\
(3.77)\end{array}$ & $\begin{array}{c}\mathbf{1 5 . 2 0} \\
(3.74)\end{array}$ & $\begin{array}{l}\mathbf{1 5 . 6 4} \\
(3.74)\end{array}$ & $\begin{array}{l}\mathbf{9 . 0 6} \\
(3.85)\end{array}$ \\
\hline \multirow[t]{2}{*}{ JCS } & $\begin{array}{l}\text { Low } \\
\text { (s.e.) }\end{array}$ & $\begin{array}{l}\mathbf{- 1 . 2 3} \\
(0.23)\end{array}$ & $\begin{array}{l}\mathbf{- 6 . 6 3} \\
(1.00)\end{array}$ & $\begin{array}{l}\mathbf{- 3 . 6 7} \\
(1.44)\end{array}$ & $\begin{array}{l}\mathbf{- 3 . 2 5} \\
(1.51)\end{array}$ & $\begin{array}{l}\mathbf{- 3 . 9 7} \\
(1.80)\end{array}$ & $\begin{array}{l}-2.97 \\
(2.22)\end{array}$ & $\begin{array}{l}-2.77 \\
(2.24)\end{array}$ & $\begin{array}{l}\mathbf{- 2 . 0 9} \\
(0.31)\end{array}$ & $\begin{array}{l}\mathbf{- 9 . 1 7} \\
(1.08)\end{array}$ & $\begin{array}{c}\mathbf{- 3 . 7 3} \\
(1.45)\end{array}$ & $\begin{array}{l}-2.61 \\
(1.46)\end{array}$ & $\begin{array}{l}-1.90 \\
(1.56)\end{array}$ & $\begin{array}{c}2.53 \\
(1.87)\end{array}$ & $\begin{array}{c}1.99 \\
(2.09)\end{array}$ \\
\hline & $\begin{array}{l}\text { High } \\
\text { (s.e.) }\end{array}$ & $\begin{array}{c}\mathbf{- 1 . 5 5} \\
(0.25)\end{array}$ & $\begin{array}{l}-5.49 \\
(1.54)\end{array}$ & $\begin{array}{c}1.42 \\
(2.39)\end{array}$ & $\begin{array}{l}-2.07 \\
(2.23)\end{array}$ & $\begin{array}{l}-0.38 \\
(2.66)\end{array}$ & $\begin{array}{l}-4.34 \\
(2.69)\end{array}$ & $\begin{array}{c}2.87 \\
(2.98)\end{array}$ & $\begin{array}{l}\mathbf{- 2 . 4 8} \\
(0.58)\end{array}$ & $\begin{array}{l}-\mathbf{- 7 . 5 7} \\
(2.89)\end{array}$ & $\begin{array}{l}-3.05 \\
(4.23)\end{array}$ & $\begin{array}{c}5.30 \\
(5.39)\end{array}$ & $\begin{array}{l}-3.25 \\
(4.80)\end{array}$ & $\begin{array}{l}-5.14 \\
(6.02)\end{array}$ & $\begin{array}{l}-5.75 \\
(6.35)\end{array}$ \\
\hline \multirow[t]{2}{*}{ FT } & $\begin{array}{l}\text { Low } \\
\text { (s.e.) }\end{array}$ & $\begin{array}{l}\mathbf{- 2 . 8 8} \\
(0.56)\end{array}$ & $\begin{array}{l}\mathbf{- 7 . 0 8} \\
(2.28)\end{array}$ & $\begin{array}{c}1.78 \\
(3.88)\end{array}$ & $\begin{array}{c}2.91 \\
(4.08)\end{array}$ & $\begin{array}{c}2.76 \\
(4.17)\end{array}$ & $\begin{array}{c}2.95 \\
(3.85)\end{array}$ & $\begin{array}{c}3.02 \\
(4.03)\end{array}$ & $\begin{array}{l}\mathbf{- 3 . 1 8} \\
(0.36)\end{array}$ & $\begin{array}{l}-\mathbf{- 7 . 1 4} \\
(2.07)\end{array}$ & $\begin{array}{l}-0.19 \\
(2.32)\end{array}$ & $\begin{array}{l}\mathbf{1 1 . 6 4} \\
(2.98)\end{array}$ & $\begin{array}{l}\mathbf{8 . 3 3} \\
(3.05)\end{array}$ & $\begin{array}{c}\mathbf{1 4 . 5 0} \\
(2.80)\end{array}$ & $\begin{array}{l}\mathbf{8 . 8 6} \\
(2.60)\end{array}$ \\
\hline & $\begin{array}{l}\text { High } \\
\text { (s.e.) }\end{array}$ & $\begin{array}{r}\mathbf{- 2 . 9 8} \\
(0.41)\end{array}$ & $\begin{array}{l}\mathbf{- 5 . 9 4} \\
(2.46)\end{array}$ & $\begin{array}{c}0.74 \\
(2.73)\end{array}$ & $\begin{array}{c}\mathbf{1 4 . 2 6} \\
(3.11)\end{array}$ & $\underset{(3.00}{\mathbf{1 6 . 2 5}}$ & $\begin{array}{c}\mathbf{1 4 . 6 3} \\
(3.14)\end{array}$ & $\begin{array}{l}\mathbf{1 2 . 2 3} \\
(3.10)\end{array}$ & $\begin{array}{l}-4.90 \\
(0.65)\end{array}$ & $\begin{array}{c}\mathbf{- 1 1 . 5 5} \\
(2.52)\end{array}$ & $\begin{array}{c}\mathbf{8 . 4 2} \\
(3.23)\end{array}$ & $\begin{array}{l}\mathbf{1 6 . 6 4} \\
(3.50)\end{array}$ & $\begin{array}{l}\mathbf{1 4 . 4 8} \\
(3.47)\end{array}$ & $\begin{array}{l}\mathbf{1 5 . 2 7} \\
(3.46)\end{array}$ & $\begin{array}{l}\mathbf{8 . 8 0} \\
(3.60)\end{array}$ \\
\hline \multirow[t]{2}{*}{$\mathrm{PT}$} & $\begin{array}{l}\text { Low } \\
\text { (s.e.) }\end{array}$ & $\begin{array}{r}-\mathbf{- 0 . 8 1} \\
(0.20)\end{array}$ & $\begin{array}{r}-4.19 \\
(1.02)\end{array}$ & $\begin{array}{l}\mathbf{- 5 . 0 2} \\
(1.07)\end{array}$ & $\begin{array}{l}-4.17 \\
(1.39)\end{array}$ & $\begin{array}{r}\mathbf{- 5 . 2 7} \\
(0.99)\end{array}$ & $\begin{array}{l}-4.71 \\
(1.51)\end{array}$ & $\begin{array}{l}-3.34 \\
(2.25)\end{array}$ & $\begin{array}{l}\mathbf{- 2 . 1 6} \\
(0.19)\end{array}$ & $\begin{array}{l}\mathbf{- 8 . 9 4} \\
(0.81)\end{array}$ & $\begin{array}{l}\mathbf{- 6 . 7 8} \\
(1.08)\end{array}$ & $\begin{array}{r}-4.49 \\
(1.26)\end{array}$ & $\begin{array}{l}\mathbf{- 5 . 5 6} \\
(1.30)\end{array}$ & $\begin{array}{l}-1.76 \\
(1.42)\end{array}$ & $\begin{array}{l}-0.37 \\
(1.70)\end{array}$ \\
\hline & $\begin{array}{l}\text { High } \\
\text { (s.e.) }\end{array}$ & $\begin{array}{r}\mathbf{- 1 . 4 0} \\
(0.27)\end{array}$ & $\begin{array}{l}\mathbf{- 6 . 5 3} \\
(1.37)\end{array}$ & $\begin{array}{c}\mathbf{- 6 . 3 4} \\
(1.43)\end{array}$ & $\begin{array}{r}\mathbf{- 6 . 2 0} \\
(1.79)\end{array}$ & $\begin{array}{c}\mathbf{- 1 0 . 8 4} \\
(1.99)\end{array}$ & $\begin{array}{r}-7.28 \\
(2.68)\end{array}$ & $\begin{array}{l}-4.37 \\
(3.44)\end{array}$ & $\begin{array}{l}\mathbf{- 2 . 7 7} \\
(0.36)\end{array}$ & $\begin{array}{c}-\mathbf{- 1 1 . 3 2} \\
(1.22)\end{array}$ & $\begin{array}{r}\mathbf{- 7 . 9 0} \\
(2.01)\end{array}$ & $\begin{array}{r}\mathbf{- 7 . 8 6} \\
(1.98)\end{array}$ & $\begin{array}{l}\mathbf{- 8 . 7 6} \\
(2.44)\end{array}$ & $\begin{array}{c}0.28 \\
(3.34)\end{array}$ & $\begin{array}{c}3.66 \\
(3.25)\end{array}$ \\
\hline \multirow[t]{2}{*}{$\mathrm{PT}^{(1)}$} & $\begin{array}{l}\text { Low } \\
\text { (s.e.) }\end{array}$ & $\begin{array}{c}\mathbf{- 7 . 8 3} \\
(0.79)\end{array}$ & $\begin{array}{c}\mathbf{- 1 2 . 8 0} \\
(1.32)\end{array}$ & $\begin{array}{l}\mathbf{2 . 1 5} \\
(2.24)\end{array}$ & $\begin{array}{c}\mathbf{1 0 . 2 1} \\
(2.68)\end{array}$ & $\begin{array}{c}\mathbf{1 0 . 6 5} \\
(2.79)\end{array}$ & $\begin{array}{l}\mathbf{5 . 6 5} \\
(2.21)\end{array}$ & $\begin{array}{c}3.07 \\
(2.08)\end{array}$ & $\begin{array}{l}\mathbf{- 6 . 0 4} \\
(0.34)\end{array}$ & $\begin{array}{l}-\mathbf{- 5 . 7 7} \\
(0.98)\end{array}$ & $\begin{array}{l}\mathbf{5 . 0 7} \\
(1.46)\end{array}$ & $\begin{array}{c}\mathbf{1 0 . 9 9} \\
(1.63)\end{array}$ & $\begin{array}{c}9.98 \\
(1.59)\end{array}$ & $\begin{array}{l}\mathbf{2 . 9 7} \\
(1.27)\end{array}$ & $\begin{array}{c}1.99 \\
(1.25)\end{array}$ \\
\hline & $\begin{array}{l}\text { High } \\
\text { (s.e.) }\end{array}$ & $\begin{array}{c}\mathbf{- 1 2 . 7 9} \\
(1.21)\end{array}$ & $\begin{array}{c}\mathbf{- 1 4 . 7 2} \\
(2.67)\end{array}$ & $\begin{array}{c}2.18 \\
(3.82)\end{array}$ & $\begin{array}{c}\mathbf{1 5 . 1 7} \\
(3.52)\end{array}$ & $\begin{array}{c}\mathbf{1 2 . 1 3} \\
(3.18)\end{array}$ & $\begin{array}{c}1.44 \\
(2.94)\end{array}$ & $\begin{array}{c}3.47 \\
(2.88)\end{array}$ & $\begin{array}{c}\mathbf{- 1 2 . 0 1} \\
(0.95)\end{array}$ & $\begin{array}{c}\mathbf{- 1 1 . 4 4} \\
(2.26)\end{array}$ & $\begin{array}{c}\mathbf{1 2 . 0 2} \\
(2.97)\end{array}$ & $\begin{array}{c}\mathbf{1 6 . 5 7} \\
(3.25)\end{array}$ & $\begin{array}{l}13.26 \\
(3.19)\end{array}$ & $\begin{array}{c}2.13 \\
(2.59)\end{array}$ & $\begin{array}{l}-2.94 \\
(2.05)\end{array}$ \\
\hline
\end{tabular}

Note: Depicted are monthly ATT estimates on employment probabilities. (1) refers to the ATT estimates on the education probabilities. Low levels of schooling indicate a lower secondary schooling qualification or none; high levels of schooling indicate a medium or higher secondary schooling qualification. Depicted are the average treatment effects (ATT) on the employment probabilities in the months following treatment entry. The ATT are written in bold when they are significant at conventional 5\%-level. Standard errors are obtained by bootstrapping with 200 replications and are depicted in parentheses.

Abbreviation index: JS: job search assistance; STT: short-term training; JWS: JUMP wage subsidies; WS: SGB III wage subsidies; FT: further training (medium to long-term); PT: preparatory training; NP: non-participants. 
Table S.8: Treatment effect heterogeneity by pretreatment schooling - cumulated effects after 30 and 60 months.

\begin{tabular}{|c|c|c|c|c|c|c|c|c|c|}
\hline & & \multicolumn{4}{|c|}{ East Germany } & \multicolumn{4}{|c|}{ West Germany } \\
\hline & \multirow[b]{2}{*}{$\sum_{\text {Education }}$} & \multicolumn{2}{|c|}{ Employment } & \multicolumn{2}{|c|}{ Education } & \multicolumn{2}{|c|}{ Employment } & \multicolumn{2}{|c|}{ Education } \\
\hline & & 30 & 60 & 30 & 60 & 30 & 60 & 30 & 60 \\
\hline \multirow[t]{2}{*}{ JS } & $\begin{array}{l}\text { Low } \\
\text { (s.e.) }\end{array}$ & $\begin{array}{l}\mathbf{1 . 3 7} \\
(0.40)\end{array}$ & $\begin{array}{l}\mathbf{3 . 2 4} \\
(0.81)\end{array}$ & $\begin{array}{r}\mathbf{- 0 . 5 7} \\
(0.19)\end{array}$ & $\begin{array}{l}-0.71 \\
(0.37)\end{array}$ & $\begin{array}{l}\mathbf{1 . 0 4} \\
(0.28)\end{array}$ & $\begin{array}{l}\mathbf{2 . 0 7} \\
(0.54)\end{array}$ & $\begin{array}{r}-\mathbf{- 0 . 7 3} \\
(0.15)\end{array}$ & $\begin{array}{l}\mathbf{- 0 . 8 5} \\
(0.28)\end{array}$ \\
\hline & $\begin{array}{l}\text { High } \\
\text { (s.e.) }\end{array}$ & $\begin{array}{l}\mathbf{2 . 5 8} \\
(0.36)\end{array}$ & $\begin{array}{l}\mathbf{5 . 9 0} \\
(0.73)\end{array}$ & $\begin{array}{r}\mathbf{- 2 . 5 2} \\
(0.21)\end{array}$ & $\begin{array}{r}\mathbf{- 3 . 6 1} \\
(0.37)\end{array}$ & $\begin{array}{l}\mathbf{1 . 9 2} \\
(0.38)\end{array}$ & $\begin{array}{l}4.22 \\
(0.79)\end{array}$ & $\begin{array}{r}-\mathbf{- 1 . 3 8} \\
(0.26)\end{array}$ & $\begin{array}{r}\mathbf{- 2 . 2 7} \\
(0.41)\end{array}$ \\
\hline \multirow[t]{2}{*}{ STT } & $\begin{array}{l}\text { Low } \\
\text { (s.e.) }\end{array}$ & $\begin{array}{l}\mathbf{1 . 2 4} \\
(0.41)\end{array}$ & $\begin{array}{l}\mathbf{3 . 2 4} \\
(0.89)\end{array}$ & $\begin{array}{r}\mathbf{- 0 . 8 7} \\
(0.30)\end{array}$ & $\begin{array}{r}\mathbf{- 1 . 2 6} \\
(0.50)\end{array}$ & $\begin{array}{l}\mathbf{1 . 3 6} \\
(0.25)\end{array}$ & $\begin{array}{l}\mathbf{3 . 5 9} \\
(0.52)\end{array}$ & $\begin{array}{c}\mathbf{- 0 . 9 4} \\
(0.16)\end{array}$ & $\begin{array}{r}\mathbf{- 1 . 0 7} \\
(0.29)\end{array}$ \\
\hline & $\underset{\text { (s.e.) }}{\text { High }}$ & $\begin{array}{l}\mathbf{2 . 1 6} \\
(0.41)\end{array}$ & $\begin{array}{l}\mathbf{5 . 4 5} \\
(0.87)\end{array}$ & $\begin{array}{r}\mathbf{- 2 . 6 1} \\
(0.26)\end{array}$ & $\begin{array}{r}\mathbf{- 3 . 3 6} \\
(0.47)\end{array}$ & $\begin{array}{l}\mathbf{2 . 1 9} \\
(0.34)\end{array}$ & $\begin{array}{l}4.45 \\
(0.68)\end{array}$ & $\begin{array}{r}\mathbf{- 2 . 1 8} \\
(0.29)\end{array}$ & $\begin{array}{r}\mathbf{- 3 . 2 7} \\
(0.47)\end{array}$ \\
\hline \multirow[t]{2}{*}{ JWS } & $\begin{array}{l}\text { Low } \\
\text { (s.e.) }\end{array}$ & $\begin{array}{l}\mathbf{4 . 0 0} \\
(0.56)\end{array}$ & $\begin{array}{l}\mathbf{1 0 . 4 9} \\
(1.26)\end{array}$ & $\begin{array}{l}\mathbf{- 1 . 1 7} \\
(0.23)\end{array}$ & $\begin{array}{l}\mathbf{- 1 . 6 8} \\
(0.40)\end{array}$ & $\begin{array}{l}\mathbf{3 . 8 3} \\
(0.44)\end{array}$ & $\begin{array}{c}\mathbf{8 . 0 1} \\
(0.87)\end{array}$ & $\begin{array}{c}-\mathbf{- 1 . 5 3} \\
(0.19)\end{array}$ & $\begin{array}{r}\mathbf{- 2 . 5 3} \\
(0.40)\end{array}$ \\
\hline & $\begin{array}{l}\text { High } \\
\text { (s.e.) }\end{array}$ & $\begin{array}{l}\mathbf{3 . 4 4} \\
(0.34)\end{array}$ & $\begin{array}{l}\mathbf{9 . 6 3} \\
(0.70)\end{array}$ & $\begin{array}{l}\mathbf{- 3 . 5 4} \\
(0.16)\end{array}$ & $\begin{array}{r}\mathbf{- 5 . 5 0} \\
(0.31)\end{array}$ & $\begin{array}{l}\mathbf{5 . 7 3} \\
(0.57)\end{array}$ & $\begin{array}{c}\mathbf{1 0 . 9 4} \\
(1.21)\end{array}$ & $\begin{array}{l}\mathbf{- 3 . 8 4} \\
(0.30)\end{array}$ & $\begin{array}{r}\mathbf{- 5 . 1 6} \\
(0.63)\end{array}$ \\
\hline \multirow[t]{2}{*}{ WS } & $\begin{array}{l}\text { Low } \\
\text { (s.e.) }\end{array}$ & $\begin{array}{l}\mathbf{3 . 3 9} \\
(0.65)\end{array}$ & $\begin{array}{c}\mathbf{6 . 6 6} \\
(1.37)\end{array}$ & $\begin{array}{r}\mathbf{- 1 . 3 8} \\
(0.32)\end{array}$ & $\begin{array}{c}\mathbf{- 2 . 0 3} \\
(0.65)\end{array}$ & $\begin{array}{l}\mathbf{2 . 2 9} \\
(0.45)\end{array}$ & $\begin{array}{l}\mathbf{4 . 6 5} \\
(0.90)\end{array}$ & $\begin{array}{c}-\mathbf{- 1 . 1 4} \\
(0.24)\end{array}$ & $\begin{array}{r}\mathbf{- 2 . 0 5} \\
(0.44)\end{array}$ \\
\hline & $\begin{array}{l}\text { High } \\
\text { (s.e.) }\end{array}$ & $\begin{array}{l}4.22 \\
(0.52)\end{array}$ & $\begin{array}{c}\mathbf{1 0 . 0 9} \\
(1.06)\end{array}$ & $\begin{array}{r}\mathbf{- 3 . 2 0} \\
(0.28)\end{array}$ & $\begin{array}{c}\mathbf{- 5 . 1 5} \\
(0.45)\end{array}$ & $\begin{array}{l}4.85 \\
(0.79)\end{array}$ & $\begin{array}{l}\mathbf{8 . 8 3} \\
(1.52)\end{array}$ & $\begin{array}{c}\mathbf{- 2 . 6 2} \\
(0.48)\end{array}$ & $\begin{array}{r}\mathbf{- 3 . 9 9} \\
(0.82)\end{array}$ \\
\hline \multirow[t]{2}{*}{ JCS } & $\begin{array}{l}\text { Low } \\
\text { (s.e.) }\end{array}$ & $\begin{array}{l}\mathbf{- 1 . 3 5} \\
(0.23)\end{array}$ & $\begin{array}{l}\mathbf{- 2 . 4 6} \\
(0.59)\end{array}$ & $\begin{array}{c}\mathbf{- 1 . 4 0} \\
(0.26)\end{array}$ & $\begin{array}{l}\mathbf{- 1 . 8 5} \\
(0.50)\end{array}$ & $\begin{array}{l}\mathbf{- 0 . 9 9} \\
(0.26)\end{array}$ & $\begin{array}{l}-1.00 \\
(0.55)\end{array}$ & $\begin{array}{l}\mathbf{- 0 . 9 8} \\
(0.25)\end{array}$ & $\begin{array}{l}-0.90 \\
(0.49)\end{array}$ \\
\hline & $\begin{array}{l}\text { High } \\
\text { (s.e.) }\end{array}$ & $\begin{array}{l}-0.74 \\
(0.43)\end{array}$ & $\begin{array}{l}-1.22 \\
(0.96)\end{array}$ & $\begin{array}{c}\mathbf{- 3 . 0 4} \\
(0.39)\end{array}$ & $\begin{array}{r}\mathbf{- 3 . 6 2} \\
(0.75)\end{array}$ & $\begin{array}{l}-0.47 \\
(0.83)\end{array}$ & $\begin{array}{l}-1.20 \\
(1.99) \\
\end{array}$ & $\begin{array}{r}\mathbf{- 3 . 5 7} \\
(0.95) \\
\end{array}$ & $\begin{array}{r}\mathbf{- 3 . 5 9} \\
(1.65) \\
\end{array}$ \\
\hline \multirow[t]{2}{*}{ FT } & $\begin{array}{l}\text { Low } \\
\text { (s.e.) }\end{array}$ & $\begin{array}{c}0.02 \\
(0.65)\end{array}$ & $\begin{array}{c}0.89 \\
(1.39)\end{array}$ & $\begin{array}{r}-\mathbf{- 1 . 2 1} \\
(0.30)\end{array}$ & $\begin{array}{l}\mathbf{- 1 . 9 8} \\
(0.51)\end{array}$ & $\begin{array}{l}\mathbf{1 . 1 1} \\
(0.51)\end{array}$ & $\begin{array}{l}4.16 \\
(1.07)\end{array}$ & $\begin{array}{c}\mathbf{- 1 . 5 2} \\
(0.22)\end{array}$ & $\begin{array}{r}\mathbf{- 2 . 0 1} \\
(0.50)\end{array}$ \\
\hline & $\begin{array}{l}\text { High } \\
\text { (s.e.) }\end{array}$ & $\begin{array}{l}\mathbf{1 . 4 7} \\
(0.55)\end{array}$ & $\begin{array}{l}\mathbf{5 . 8 9} \\
(1.16)\end{array}$ & $\begin{array}{r}\mathbf{- 3 . 1 5} \\
(0.30)\end{array}$ & $\begin{array}{l}-4.76 \\
(0.57)\end{array}$ & $\begin{array}{l}\mathbf{2 . 6 4} \\
(0.66)\end{array}$ & $\begin{array}{c}\mathbf{6 . 6 9} \\
(1.39)\end{array}$ & $\begin{array}{r}\mathbf{- 2 . 7 5} \\
(0.42)\end{array}$ & $\begin{array}{r}\mathbf{- 3 . 8 7} \\
(0.72)\end{array}$ \\
\hline \multirow[t]{2}{*}{$\mathrm{PT}$} & $\begin{array}{l}\text { Low } \\
\text { (s.e.) }\end{array}$ & $\begin{array}{l}\mathbf{- 1 . 1 0} \\
(0.21)\end{array}$ & $\begin{array}{l}\mathbf{- 2 . 3 0} \\
(0.44)\end{array}$ & $\begin{array}{c}0.72 \\
(0.48)\end{array}$ & $\begin{array}{c}\mathbf{2 . 7 3} \\
(0.84)\end{array}$ & $\begin{array}{l}\mathbf{- 1 . 6 1} \\
(0.20)\end{array}$ & $\begin{array}{c}\mathbf{- 2 . 5 0} \\
(0.43)\end{array}$ & $\begin{array}{l}\mathbf{1 . 2 8} \\
(0.31)\end{array}$ & $\begin{array}{c}\mathbf{2 . 9 8} \\
(0.52)\end{array}$ \\
\hline & $\begin{array}{l}\text { High } \\
\text { (s.e.) }\end{array}$ & $\begin{array}{r}\mathbf{- 1 . 6 4} \\
(0.31)\end{array}$ & $\begin{array}{r}\mathbf{- 4 . 2 0} \\
(0.72)\end{array}$ & $\begin{array}{c}0.66 \\
(0.77)\end{array}$ & $\begin{array}{c}\mathbf{2 . 6 0} \\
(1.11)\end{array}$ & $\begin{array}{r}\mathbf{- 2 . 1 7} \\
(0.38)\end{array}$ & $\begin{array}{r}\mathbf{- 3 . 0 7} \\
(0.89)\end{array}$ & $\begin{array}{l}\mathbf{1 . 8 6} \\
(0.65)\end{array}$ & $\begin{array}{c}\mathbf{3 . 6 9} \\
(1.06)\end{array}$ \\
\hline
\end{tabular}

Note: Low levels of schooling indicate a lower secondary schooling qualification or none; high levels of schooling indicate a medium or higher secondary schooling qualification. Depicted are the cumulated treatment effects, summing up the monthly ATT between for 30 or 60 months following treatment entry. The effects are written in bold when they are significant at conventional 5\%-level. Standard errors are obtained by bootstrapping with 200 replications and are depicted in parentheses.

Abbreviation index: JS: job search assistance; STT: short-term training; JWS: JUMP wage subsidies; WS: $S G B I I I$ wage subsidies; FT: further training (medium to long-term); PT: preparatory training; NP: non-participants. 
\%subsectionSensitivity Analysis

Table S.9: Sensitivity of the employment effect estimates

\begin{tabular}{|c|c|c|c|c|c|c|c|c|c|c|c|c|c|c|}
\hline \multicolumn{15}{|c|}{ East Germany } \\
\hline \multirow[b]{2}{*}{$\sum$} & \multicolumn{2}{|c|}{ JS } & \multicolumn{2}{|c|}{ STT } & \multicolumn{2}{|c|}{ JWS } & \multicolumn{2}{|c|}{ WS } & \multicolumn{2}{|c|}{ JCS } & \multicolumn{2}{|c|}{ FT } & \multicolumn{2}{|c|}{$\mathrm{PT}$} \\
\hline & 30 & 60 & 30 & 60 & 30 & 60 & 30 & 60 & 30 & 60 & 30 & 60 & 30 & 60 \\
\hline \multicolumn{15}{|c|}{ Results from the main analysis } \\
\hline $\begin{array}{l}\text { ATT } \\
\text { (s.e) }\end{array}$ & $\begin{array}{l}\mathbf{1 . 4 9} \\
(0.25)\end{array}$ & $\begin{array}{l}\mathbf{3 . 8 1} \\
(0.54)\end{array}$ & $\begin{array}{l}\mathbf{1 . 2 7} \\
(0.31)\end{array}$ & $\begin{array}{l}\mathbf{3 . 6 5} \\
(0.57)\end{array}$ & $\begin{array}{l}\mathbf{3 . 1 0} \\
(0.31)\end{array}$ & $\begin{array}{l}\mathbf{9 . 0 9} \\
(0.62)\end{array}$ & $\begin{array}{l}\mathbf{3 . 5 3} \\
(0.49)\end{array}$ & $\begin{array}{c}\mathbf{8 . 4 9} \\
(1.02)\end{array}$ & $\begin{array}{l}\mathbf{- 1 . 4 7} \\
(0.25)\end{array}$ & $\begin{array}{l}\mathbf{- 2 . 3 8} \\
(0.56)\end{array}$ & $\begin{array}{c}0.27 \\
(0.44)\end{array}$ & $\begin{array}{l}\mathbf{2 . 8 6} \\
(0.98)\end{array}$ & $\begin{array}{l}\mathbf{- 1 . 6 4} \\
(0.20)\end{array}$ & $\begin{array}{l}\mathbf{- 3 . 4 3} \\
(0.43)\end{array}$ \\
\hline \multicolumn{15}{|c|}{ A) Further program participation } \\
\hline $\begin{array}{l}\text { ATT } \\
\text { (s.e) }\end{array}$ & $\begin{array}{l}\mathbf{2 . 1 6} \\
(0.32)\end{array}$ & $\begin{array}{l}3.92 \\
(0.61)\end{array}$ & $\begin{array}{l}\mathbf{1 . 5 3} \\
(0.36)\end{array}$ & $\begin{array}{l}\mathbf{3 . 6 1} \\
(0.70)\end{array}$ & $\begin{array}{l}\mathbf{3 . 3 3} \\
(0.32)\end{array}$ & $\begin{array}{l}\mathbf{9 . 3 7} \\
(0.64)\end{array}$ & $\begin{array}{l}4.09 \\
(0.47)\end{array}$ & $\begin{array}{l}\mathbf{9 . 5 5} \\
(0.95)\end{array}$ & $\begin{array}{l}\mathbf{- 1 . 3 7} \\
(0.26)\end{array}$ & $\begin{array}{c}\mathbf{- 2 . 3 2} \\
(0.60)\end{array}$ & $\begin{array}{c}0.43 \\
(0.48)\end{array}$ & $\begin{array}{l}\mathbf{2 . 7 5} \\
(1.04)\end{array}$ & $\begin{array}{l}\mathbf{- 1 . 5 7} \\
(0.24)\end{array}$ & $\begin{array}{l}\mathbf{- 3 . 3 0} \\
(0.53)\end{array}$ \\
\hline \multicolumn{15}{|c|}{ B) Dynamic evaluation approach } \\
\hline $\begin{array}{l}\text { ATT } \\
\text { (s.e) }\end{array}$ & $\begin{array}{l}\mathbf{1 . 7 0} \\
(0.23)\end{array}$ & $\begin{array}{l}\mathbf{3 . 9 5} \\
(0.52)\end{array}$ & $\begin{array}{l}\mathbf{1 . 4 8} \\
(0.27)\end{array}$ & $\begin{array}{l}\mathbf{3 . 8 1} \\
(0.56)\end{array}$ & $\begin{array}{l}\mathbf{3 . 3 1} \\
(0.27)\end{array}$ & $\begin{array}{l}\mathbf{9 . 0 9} \\
(0.57)\end{array}$ & $\begin{array}{l}\mathbf{3 . 7 8} \\
(0.44)\end{array}$ & $\begin{array}{l}\mathbf{8 . 5 7} \\
(0.88)\end{array}$ & $\begin{array}{l}\mathbf{- 1 . 3 1} \\
(0.24)\end{array}$ & $\begin{array}{c}\mathbf{- 2 . 2 2} \\
(0.54)\end{array}$ & $\begin{array}{c}0.44 \\
(0.41)\end{array}$ & $\begin{array}{l}\mathbf{2 . 9 1} \\
(0.90)\end{array}$ & $\begin{array}{l}\mathbf{- 1 . 4 4} \\
(0.20)\end{array}$ & $\begin{array}{l}\mathbf{- 3 . 1 9} \\
(0.46)\end{array}$ \\
\hline \multicolumn{15}{|c|}{ C) Alternative imposition of common support } \\
\hline $\begin{array}{l}\text { C1) } \\
\text { s.e) }\end{array}$ & $\begin{array}{l}\mathbf{1 . 6 2} \\
(0.28)\end{array}$ & $\begin{array}{l}\mathbf{4 . 1 5} \\
(0.56)\end{array}$ & $\begin{array}{l}\mathbf{1 . 2 8} \\
(0.30)\end{array}$ & $\begin{array}{l}\mathbf{3 . 5 8} \\
(0.56)\end{array}$ & $\begin{array}{l}\mathbf{3 . 3 2} \\
(0.31)\end{array}$ & $\begin{array}{l}\mathbf{9 . 5 3} \\
(0.60)\end{array}$ & $\begin{array}{l}\mathbf{3 . 6 1} \\
(0.45)\end{array}$ & $\begin{array}{l}\mathbf{8 . 6 5} \\
(0.92)\end{array}$ & $\begin{array}{l}\mathbf{- 1 . 6 1} \\
(0.26)\end{array}$ & $\begin{array}{l}-\mathbf{- 2 . 7 1} \\
(0.58)\end{array}$ & $\begin{array}{c}0.32 \\
(0.44)\end{array}$ & $\begin{array}{l}\mathbf{2 . 9 9} \\
(0.88)\end{array}$ & \begin{tabular}{|l|}
$\mathbf{- 1 . 6 3}$ \\
$(0.20)$
\end{tabular} & $\begin{array}{l}\mathbf{- 3 . 5 6} \\
(0.46)\end{array}$ \\
\hline $\begin{array}{l}\text { C2) } \\
\text { (s.e) }\end{array}$ & $\begin{array}{l}\mathbf{1 . 1 9} \\
(0.28)\end{array}$ & $\begin{array}{c}\mathbf{3 . 4 2} \\
(0.59)\end{array}$ & $\begin{array}{l}\mathbf{1 . 0 3} \\
(0.37)\end{array}$ & $\begin{array}{c}\mathbf{3 . 5 4} \\
(0.73)\end{array}$ & $\begin{array}{l}\mathbf{2 . 6 6} \\
(0.37)\end{array}$ & $\begin{array}{l}\mathbf{8 . 5 2} \\
(0.69)\end{array}$ & $\begin{array}{c}\mathbf{3 . 4 6} \\
(0.55)\end{array}$ & $\begin{array}{l}\mathbf{8 . 7 5} \\
(1.17)\end{array}$ & $\begin{array}{l}\mathbf{- 2 . 0 7} \\
(0.30)\end{array}$ & $\begin{array}{c}\mathbf{- 3 . 4 0} \\
(0.64)\end{array}$ & $\begin{array}{c}0.03 \\
(0.53)\end{array}$ & $\begin{array}{l}\mathbf{2 . 5 6} \\
(1.19)\end{array}$ & $\begin{array}{l}\mathbf{- 1 . 7 8} \\
(0.30)\end{array}$ & $\begin{array}{l}\mathbf{- 3 . 6 3} \\
(0.63)\end{array}$ \\
\hline $\begin{array}{l}\text { C3) ATT } \\
\text { (s.e) }\end{array}$ & $\begin{array}{l}\mathbf{1 . 7 3} \\
(0.33)\end{array}$ & $\begin{array}{l}4.39 \\
(0.64)\end{array}$ & $\begin{array}{l}\mathbf{1 . 5 2} \\
(0.32)\end{array}$ & $\begin{array}{l}\mathbf{3 . 9 9} \\
(0.62)\end{array}$ & $\begin{array}{l}\mathbf{3 . 3 2} \\
(0.31)\end{array}$ & $\begin{array}{l}\mathbf{9 . 2 2} \\
(0.70)\end{array}$ & $\begin{array}{l}\mathbf{3 . 5 9} \\
(0.47)\end{array}$ & $\begin{array}{l}\mathbf{8 . 8 2} \\
(0.98)\end{array}$ & $\begin{array}{r}\mathbf{- 1 . 4 9} \\
(0.30)\end{array}$ & $\begin{array}{c}\mathbf{- 2 . 4 4} \\
(0.71)\end{array}$ & $\begin{array}{c}0.26 \\
(0.62)\end{array}$ & $\begin{array}{l}\mathbf{3 . 0 8} \\
(1.22)\end{array}$ & $\begin{array}{l}\mathbf{- 1 . 6 3} \\
(0.29)\end{array}$ & $\begin{array}{r}\mathbf{- 3 . 1 8} \\
(0.63)\end{array}$ \\
\hline \multicolumn{15}{|c|}{ West Germany } \\
\hline & \multicolumn{2}{|c|}{ JS } & \multicolumn{2}{|c|}{ STT } & \multicolumn{2}{|c|}{ JWS } & \multicolumn{2}{|c|}{ WS } & \multicolumn{2}{|c|}{ JCS } & \multicolumn{2}{|c|}{ FT } & \multicolumn{2}{|c|}{$\mathrm{PT}$} \\
\hline$\sum$ & 30 & 60 & 30 & 60 & 30 & 60 & 30 & 60 & 30 & 60 & 30 & 60 & 30 & 60 \\
\hline \multicolumn{15}{|c|}{ Results from the main analysis } \\
\hline $\begin{array}{l}\text { ATT } \\
\text { (s.e.) }\end{array}$ & $\begin{array}{l}\mathbf{1 . 3 7} \\
(0.22)\end{array}$ & $\begin{array}{l}\mathbf{2 . 8 5} \\
(0.42)\end{array}$ & $\begin{array}{c}\mathbf{0 . 9 8} \\
(0.23)\end{array}$ & $\begin{array}{l}\mathbf{2 . 7 5} \\
(0.45)\end{array}$ & $\begin{array}{l}4.16 \\
(0.38)\end{array}$ & $\begin{array}{l}\mathbf{8 . 5 3} \\
(0.71)\end{array}$ & $\begin{array}{l}\mathbf{2 . 4 2} \\
(0.47)\end{array}$ & $\begin{array}{l}4.92 \\
(0.86)\end{array}$ & $\begin{array}{l}\mathbf{- 1 . 3 8} \\
(0.30)\end{array}$ & $\begin{array}{l}\mathbf{- 1 . 6 3} \\
(0.64)\end{array}$ & $\begin{array}{l}\mathbf{1 . 2 3} \\
(0.44)\end{array}$ & $\begin{array}{l}4.47 \\
(0.83)\end{array}$ & \begin{tabular}{|l|}
$\mathbf{- 2 . 1 4}$ \\
$(0.20)$
\end{tabular} & $\begin{array}{l}\mathbf{- 3 . 0 9} \\
(0.42)\end{array}$ \\
\hline \multicolumn{15}{|c|}{ A) Further program participation } \\
\hline $\begin{array}{l}\text { ATT } \\
\text { (s.e.) }\end{array}$ & $\begin{array}{l}\mathbf{2 . 4 3} \\
(0.25)\end{array}$ & $\begin{array}{l}\mathbf{4 . 2 9} \\
(0.49)\end{array}$ & $\begin{array}{l}\mathbf{1 . 5 7} \\
(0.26)\end{array}$ & $\begin{array}{l}\mathbf{3 . 2 2} \\
(0.48)\end{array}$ & $\begin{array}{l}\mathbf{4 . 4 9} \\
(0.36)\end{array}$ & $\begin{array}{l}\mathbf{9 . 0 9} \\
(0.72)\end{array}$ & $\begin{array}{l}\mathbf{2 . 9 7} \\
(0.50)\end{array}$ & $\begin{array}{l}\mathbf{5 . 3 3} \\
(0.98)\end{array}$ & $\begin{array}{l}\mathbf{- 1 . 1 5} \\
(0.31)\end{array}$ & $\begin{array}{l}-1.13 \\
(0.66)\end{array}$ & $\begin{array}{l}\mathbf{1 . 3 2} \\
(0.41)\end{array}$ & $\begin{array}{l}\mathbf{4 . 6 5} \\
(0.84)\end{array}$ & $\begin{array}{l}\mathbf{- 2 . 0 7} \\
(0.21)\end{array}$ & $\begin{array}{r}\mathbf{- 2 . 9 0} \\
(0.47)\end{array}$ \\
\hline \multicolumn{15}{|c|}{ B) Dynamic evaluation approach } \\
\hline $\begin{array}{l}\text { ATT } \\
\text { (s.e.) }\end{array}$ & $\begin{array}{l}\mathbf{1 . 5 2} \\
(0.21)\end{array}$ & $\begin{array}{l}\mathbf{2 . 9 5} \\
(0.42)\end{array}$ & $\begin{array}{l}\mathbf{1 . 1 3} \\
(0.22)\end{array}$ & $\begin{array}{l}\mathbf{2 . 9 1} \\
(0.42)\end{array}$ & $\begin{array}{l}\mathbf{4 . 1 6} \\
(0.32)\end{array}$ & $\begin{array}{l}\mathbf{8 . 4 4} \\
(0.61)\end{array}$ & $\begin{array}{l}\mathbf{2 . 5 0} \\
(0.43)\end{array}$ & $\begin{array}{l}4.93 \\
(0.86)\end{array}$ & $\begin{array}{r}-\mathbf{- 1 . 2 0} \\
(0.30)\end{array}$ & $\begin{array}{l}\mathbf{- 1 . 3 4} \\
(0.60)\end{array}$ & $\begin{array}{l}\mathbf{1 . 2 8} \\
(0.41)\end{array}$ & $\begin{array}{l}4.46 \\
(0.86)\end{array}$ & \begin{tabular}{|l|}
$\mathbf{- 1 . 9 2}$ \\
$(0.18)$
\end{tabular} & $\begin{array}{l}\mathbf{- 2 . 8 5} \\
(0.41)\end{array}$ \\
\hline \multicolumn{15}{|c|}{ C) Alternative imposition of common support } \\
\hline $\begin{array}{l}\text { C1) ATT } \\
\text { (s.e.) }\end{array}$ & $\begin{array}{l}\mathbf{1 . 4 4} \\
(0.21)\end{array}$ & $\begin{array}{l}\mathbf{2 . 9 5} \\
(0.42)\end{array}$ & $\begin{array}{l}\mathbf{1 . 0 2} \\
(0.21)\end{array}$ & $\begin{array}{l}\mathbf{2 . 7 8} \\
(0.43)\end{array}$ & $\begin{array}{l}\mathbf{4 . 2 4} \\
(0.36)\end{array}$ & $\begin{array}{l}\mathbf{8 . 6 8} \\
(0.69)\end{array}$ & $\begin{array}{l}\mathbf{2 . 4 9} \\
(0.44)\end{array}$ & $\begin{array}{c}\mathbf{5 . 0 0} \\
(0.84)\end{array}$ & $\begin{array}{l}-\mathbf{- 1 . 5 0} \\
(0.28)\end{array}$ & $\begin{array}{c}\mathbf{- 1 . 9 3} \\
(0.62)\end{array}$ & $\begin{array}{l}\mathbf{1 . 2 9} \\
(0.44)\end{array}$ & $\begin{array}{l}\mathbf{4 . 6 1} \\
(0.85)\end{array}$ & $\begin{array}{l}\mathbf{- 2 . 1 7} \\
(0.20)\end{array}$ & $\begin{array}{r}\mathbf{- 3 . 1 7} \\
(0.46)\end{array}$ \\
\hline $\begin{array}{l}\text { C2) ATT } \\
\text { (s.e.) }\end{array}$ & $\begin{array}{l}\mathbf{1 . 0 9} \\
(0.28)\end{array}$ & $\begin{array}{c}\mathbf{2 . 4 3} \\
(0.54)\end{array}$ & $\begin{array}{c}\mathbf{0 . 7 0} \\
(0.27)\end{array}$ & $\begin{array}{l}\mathbf{2 . 3 9} \\
(0.53)\end{array}$ & $\begin{array}{l}\mathbf{3 . 7 6} \\
(0.42)\end{array}$ & $\begin{array}{l}\mathbf{8 . 2 5} \\
(0.82)\end{array}$ & $\begin{array}{l}\mathbf{1 . 8 3} \\
(0.52)\end{array}$ & $\begin{array}{l}\mathbf{3 . 8 7} \\
(0.98)\end{array}$ & $\begin{array}{r}\mathbf{- 1 . 7 9} \\
(0.36)\end{array}$ & $\begin{array}{r}\mathbf{- 2 . 2 3} \\
(0.78)\end{array}$ & $\begin{array}{c}0.83 \\
(0.48)\end{array}$ & $\begin{array}{l}\mathbf{4 . 0 4} \\
(0.98)\end{array}$ & $\begin{array}{c}\mathbf{- 2 . 1 3} \\
(0.25)\end{array}$ & $\begin{array}{c}\mathbf{- 3 . 0 6} \\
(0.51)\end{array}$ \\
\hline $\begin{array}{l}\text { C3) ATT } \\
\text { (s.e.) }\end{array}$ & $\begin{array}{l}\mathbf{1 . 7 8} \\
(0.30)\end{array}$ & $\begin{array}{c}\mathbf{3 . 4 9} \\
(0.55)\end{array}$ & $\begin{array}{l}\mathbf{1 . 2 7} \\
(0.25)\end{array}$ & $\begin{array}{c}\mathbf{3 . 4 3} \\
(0.48)\end{array}$ & $\begin{array}{l}\mathbf{4 . 2 0} \\
(0.35)\end{array}$ & $\begin{array}{l}\mathbf{8 . 6 0} \\
(0.73)\end{array}$ & $\begin{array}{l}\mathbf{2 . 7 2} \\
(0.44)\end{array}$ & $\begin{array}{l}\mathbf{5 . 2 7} \\
(0.86)\end{array}$ & $\begin{array}{l}\mathbf{- 1 . 1 5} \\
(0.35)\end{array}$ & $\begin{array}{c}\mathbf{- 1 . 4 0} \\
(0.81)\end{array}$ & $\begin{array}{l}\mathbf{1 . 3 7} \\
(0.45)\end{array}$ & $\begin{array}{l}\mathbf{4 . 6 8} \\
(0.89)\end{array}$ & $\begin{array}{l}\mathbf{- 1 . 9 6} \\
(0.23)\end{array}$ & $\begin{array}{r}\mathbf{- 2 . 8 2} \\
(0.53)\end{array}$ \\
\hline
\end{tabular}

Note: The cumulative effects are obtained by summing up the monthly program effects over a period of 30 or 60 months after program entry. Standard errors in parentheses are obtained by bootstrapping the estimation procedure with 200 replications. Bold numbers indicate significance at the $5 \%$ level. The results from the main analysis are the aggregate cumulative effects from Table 5 .

Sensitivity A) refers to the exclusion of further program participants within one year of unemployment duration.

Sensitivity B) refers to the extension of the control group to all future program participants and other program participants.

Sensitivity $C$ ) refers to modifications in the PS distribution that is used to weigh the nonparticipant outcomes. We estimate the effects in C1) by excluding non-participants with PS-values above the 99th percentile. In C2) we only include participants and non-participants in the analysis within the optimal region of common support: $\alpha<P(W)<(1-\alpha)$ as suggested by Crump, Hotz, Imbens, and Mitnik (2009). For C3) we divide the PS-distribution in 20 equidistant percentiles, and only estimate the ATT in regions where the density is above $5 \%(F(P(W)>5 \%)$ in both groups.

Abbreviation index: JS: job search assistance; STT: short-term training; JWS: JUMP wage subsidies; WS: SGB III wage subsidies; FT: further training (medium to long-term); PT: preparatory training; NP: non-participants. 